University of Michigan Law School University of Michigan Law School Scholarship Repository

2000

\title{
Globalization, Tax Competition, and the Fiscal Crisis of the Welfare State
}

Reuven S. Avi-Yonah

University of Michigan Law School, aviyonah@umich.edu

Available at: https://repository.law.umich.edu/articles/50

Follow this and additional works at: https://repository.law.umich.edu/articles

Cart of the Taxation-Transnational Commons, Tax Law Commons, and the Transnational Law Commons

\section{Recommended Citation}

Avi-Yonah, Reuven S. "Globalization, Tax Competition, and the Fiscal Crisis of the Welfare State." Harv. L. Rev. 113 , no. 7 (2000): 1573-676.

This Article is brought to you for free and open access by the Faculty Scholarship at University of Michigan Law School Scholarship Repository. It has been accepted for inclusion in Articles by an authorized administrator of University of Michigan Law School Scholarship Repository. For more information, please contact mlaw.repository@umich.edu. 


\title{
HARVARD LAW REVIEW
}

\author{
ARTICLE \\ GLOBALIZATION, TAX COMPETITION, AND \\ THE FISCAL CRISIS OF THE WELFARE STATE
}

\author{
Reuven S. Avi-Yonah \\ TABLE OF CONTENTS
}

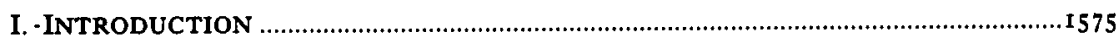

II. INTERNATIONAL TAX COMPETITION AND THE TAXATION OF CAPITAL ........... 1579

A. Taxation of Savings: Portfolio Exemptions, Traditional Tax Havens, and the Global Tax. 1579

B. Taxation of Multinationals: Permanent Establishments and

Headquarters and Production Tax Havens......................................................... 1586

I. Demand Jurisdictions and the Permanent Establishment Threshold......................1587

2. Supply Jurisdictions and Production Tax Havens...............................................1588

3. Corporate Residence Jurisdictions and Headquarters Tax Havens.......................1593

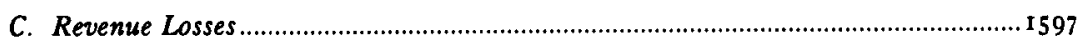

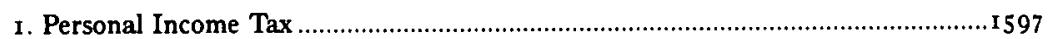

2. Corporate Income Tax ……………………………........................................

III. The PRoblem of TAX Competition from a Global

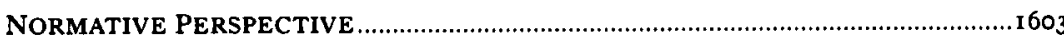

A. Global Efficiency and Global Welfare............................................................. 604

r. Capital Export Neutrality and Capital Import Neutrality ................................. 604

2. Welfare Economics and Public Choice ................................................................. 6 I I

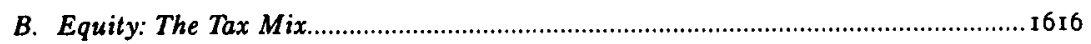

C. Democracy: Two Types of Tax Competition............................................................. 625

IV. THE COSTS AND BENEFITS OF TAX COMPETITION FROM EACH

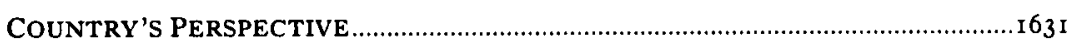

A. Developed Countries and the Fiscal Crisis of the Welfare State ............................... 1632

B. Developing Countries and Tax Incentives........................................................... . 639

I. Do Developing Countries Need Tax Revenues? ................................................. I640

2. Should Developing Countries Tax Foreign Investors? ................................... 164 I

3. Do Developing Countries Need to Offer Tax Incentives

to Attract Foreign Investment? .......................................................................... 643

C. Inter-Nation Equity and the Division of Global Tax Revenues...............................1648 


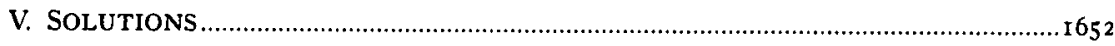

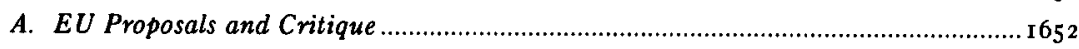

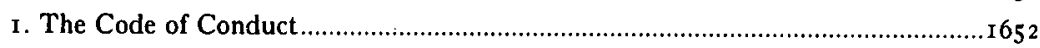

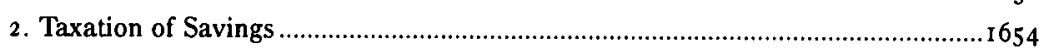

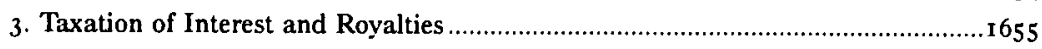

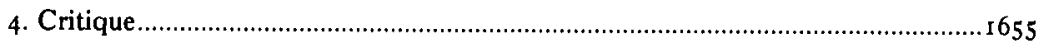

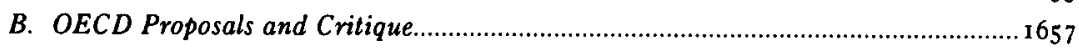

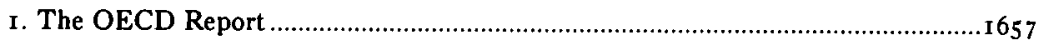

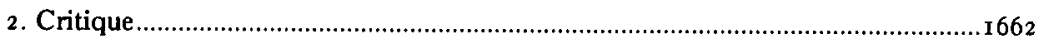

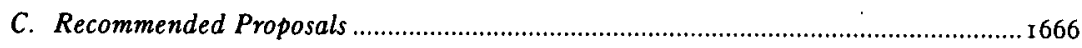

1. A Uniform Withholding Tax on Portfolio Investment ...................................... 667

2. Consumption-Based Taxation of Multinationals ................................................. 670

(a) A Gross Withholding Tax......................................................................... 672

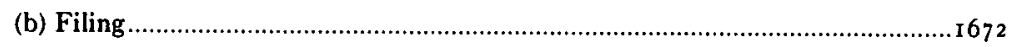

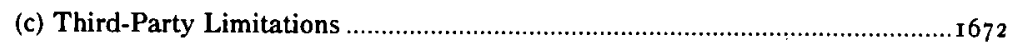

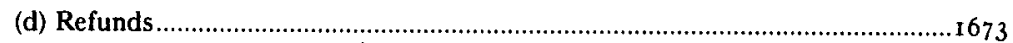

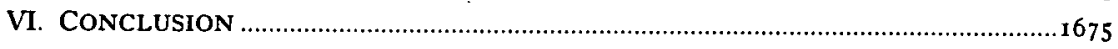




\title{
GLOBALIZATION, TAX COMPETITION, AND THE FISCAL CRISIS OF THE WELFARE STATE
}

\author{
Reuven S. Avi-Yonah*
}

This Article examines the increased use of tax incentives as weapons in the international competition to attract investment. Professor Avi-Yonah argues that the establishment of tax havens allows large amounts of capital to go untaxed, depriving both developed and developing countries of revenue and forcing them to rely on forms of taxation less progressive than the income tax. He points to social insurance programs, many of which are already on uncertain courses as aging populations imperil their fiscal health, as likely to bear the brunt of the revenue loss that tax havens cause. Professor Avi-Yonah contends that both economic efficiency and equity among individuals and among nations support limits on international tax competition, and he presents a proposal that accommodates the competing concem for democratic states' ability to set their tax rates independently. He proposes the coordinated imposition of withholding taxes on intermational portfolio investment, with the goal of ensuring that all income may be taxed in the investor's home jurisdiction. Professor Avi-Yonah also proposes that multinational corporations be taxed initially in the jurisdictions where their goods and services are consumed. Under the framework this Article outlines, both developed and developing nations would be able to preserve the progressivity of the income tax and to broaden and stabilize their tax bases in time to stave off the fiscal threat to the welfare state.

\section{INTRODUCTION}

$\mathrm{I}^{\mathrm{n}}$ the current age of globalization, capital is much more mobile than labor. In the previous age, which lasted roughly from I870 to I9I4 (before immigration restrictions), labor was at least as mobile as capital. This increased mobility of capital is the result of such technological advances as the electronic transfer of funds and the relaxation of exchange controls. The mobility of capital has resulted in international tax competition, in which sovereign countries aim to attract both portfolio and direct investment by lowering their tax rates on in-

- Assistant Professor of Law, Harvard Law School. I would like to thank the participants in workshops at Georgetown, Harvard, Michigan, Minnesota, NYU, Penn, UCLA, and Virginia law schools, as well as participants in the 1999 Harvard Seminar on Current Research in Taxation, the G-24 Technical Advisory Group, and the 1999-2000 MacArthur Workshop on Transnational Economic Security, for their helpful comments on previous versions of this Article. Special thanks are due to Bill Andrews, Hugh Ault, Lucian Bebchuk, David Bradford, David Charny, Wouter van Ginneken, Michael Graetz, Joe Guttentag, Daniel Halperin, Jim Hines, Robert Howse, Howell Jackson, Louis Kaplow, David Kennedy, Duncan Kennedy, Robert Kuttner, Lance Lindblom, Jack Mintz, Dani Rodrik, Dan Shaviro, Reed Shuldiner, Joel Slemrod, Deborah Spar, Emil Sunley, Vito Tanzi, Louis Wells, Philip West, and Bernard Wolfman for their comments, to Stephanie Hunter for her meticulous and insightful research assistance, and to the Ford Foundation for its generous support. This Article is dedicated to Orli Avi-Yonah for her unfailing inspiration and love, without which it would never have been written. 
come earned by foreigners. Tax competition, in turn, threatens to undermine the individual and corporate income taxes, which traditionally have generated the largest share of revenue for modern welfare states. The developed countries have responded in two ways: first, by shifting the tax burden from (mobile) capital to (less mobile) labor, and second, when increased taxation of labor has become politically and economically problematic, by reducing the social safety net. Thus, globalization and tax competition lead to fiscal crises for countries that wish to continue to provide social insurance; at the same time, demographic factors and the increased income inequality, job insecurity, and income volatility that result from globalization render such social insurance all the more necessary. These crises pressure nations to limit globalization (for example, by re-introducing exchange controls), an act that risks reducing world welfare. This Article argues that maintaining both globalization and social insurance will require measures that limit tax competition but preserve each democratic state's ability to determine the size of its public sector.

From its inception in the late nineteenth century through the recent rise of payroll taxation, the welfare state has been financed primarily through progressive income taxation. Unlike other forms of taxation (such as consumption or social security taxes), the income tax includes income from capital in the tax base, even if that income is saved and not consumed. Because the rich save more than do the poor, a tax that includes income from capital in its base is more progressive than a tax that excludes income from capital (such as a consumption tax or a payroll tax). However, greater capital mobility and international tax competition allow investors to escape taxation easily by shifting capital to low- or no-tax jurisdictions. Consequently, the income tax's progressive effect is significantly weakened.

Two recent developments have dramatically augmented individuals' and corporations' ability to earn tax-free overseas income: the effective end of withholding taxation by developed countries and the rise of production tax havens in developing countries. Since the United States abolished its withholding tax on interest paid to foreigners in 1984, no major capital-importing country has been able to impose such a tax for fear of driving mobile capital elsewhere (or increasing the cost of capital for domestic borrowers, including the government itself). As a result, individuals can generally earn investment income free of hostcountry taxation in any of the world's major economies. Second, tax havens with strong bank secrecy laws have made it exceedingly difficult for developed countries - let alone developing countries with their weaker tax administrations - to collect tax on the foreign income of their individual residents in the absence of withholding taxes in the host countries. Thus, cross-border investment income can largely be earned free of either host- or home-country taxation. 
A similar threat to the taxing capacity of both home and host jurisdictions has emerged in the context of productive investment. In the last decade, competition for inbound investment has led an increasing number of countries ( $\mathrm{IO}_{3}$ as of 1998 ) to offer reductions in the effective tax rate ("tax holidays") to foreign corporate investors. ${ }^{1}$ Given the relative ease with which an integrated multinational corporation can relocate production facilities in response to tax rates, such "production tax havens" enable multinationals to derive most of their income from abroad, free of host-country taxation. Moreover, these multinationals generally manage to escape home-country taxation as well. Most developed countries (including the United States) do not dare impose current taxation (or, in some cases, any taxation) on the foreign source business income of their resident multinationals for fear of reducing their multinationals' ability to compete against multinationals of other countries. If they did, new multinationals would choose to become residents of jurisdictions that do not tax such foreign source income. Thus, businesses can earn income abroad largely free of either host- or home-country taxation.

If much of both passive and productive income from capital can escape the tax net, the income tax becomes in effect a tax on labor. Several empirical studies have suggested that in some developed countries, the effective tax rate on income from capital approaches zero. Since the early I 980 , when exchange controls were relaxed, nominal tax rates have gone down sharply. As a result, countries that formerly relied on income tax revenues now must increase relatively regressive taxes, such as consumption and payroll taxes, which in recent years have been the two fastest growing taxes in the member countries of the Organization for Economic Co-operation and Development (OECD). ${ }^{2}$ Moreover, there is evidence that as an OECD member country's economy becomes more open, its taxes on capital tend to go down while its taxes on labor go up. ${ }^{3}$

\footnotetext{
1 See Raymond Vernon, in the hurricane's Eye: The troubled Prospects of MULTINATIONAL ENTERPRISES 32 tbl.2-I (1998) (citing UNITED NATIONS, INCENTIVES AND FOREIGN DIRECT INVESTMENT tbl.III.2 (1996)).

2 Consumption taxes represented $12 \%$ of OECD members' total revenues in I 965 and $18 \%$ in 1995 ; payroll taxes rose from $18 \%$ to $25 \%$ over that time. Moreover, during the same period, neither the personal nor the corporate income tax has grown as a percentage of total revenues (the personal income tax accounted for $26 \%$ of total revenues in 1965 and $27 \%$ in 1995 ; the corporate income tax, nine percent and eight percent, respectively). See infra p. I6rg tbl.2. The total tax revenue as a percentage of GDP in developed countries went up sharply during the same period (from an average of $28 \%$ in 1965 to almost $40 \%$ in 1994 ), an increase largely attributable to the rise in consumption and payroll taxes.

3 Because the income tax is imposed on both capital and labor, the stability of its overall receipts, see, e.g., Vito Tanzi, Globalization, Tax Competition and the Future of Tax Systems, in STEUERSYSTEME DER ZUKUNFT I I, I (Gerold Krause-Junk ed., I 998), may mask this trend.
} 
At some point, developed countries find themselves politically unable to raise income taxes on labor, consumption taxes, or payroll taxes any further. High income taxes on labor discourage work, high payroll taxes discourage job creation and contribute to unemployment, and high consumption taxes (for example, on luxury goods) drive consumption overseas. If developed countries are unable to tax income from capital and if alternative taxes are not feasible, their only recourse is to cut the social safety net - a net that is needed more than ever both because of demographic factors and because of the increased income inequality, income volatility, and job insecurity that tend to result from globalization. Thus, globalization leads to a more pressing need for revenues at the same time that it limits governments' ability to collect those revenues.

This dilemma threatens to undercut the social consensus about the value of the welfare state that underlies modern industrialized societies and to create a backlash against the globalization that produces so many overall benefits. The previous age of globalization collapsed in the I920s in the face of just such a backlash. Maintaining the social compact underlying the modern welfare state requires a means of taxing cross-border income from capital at rates that approximate the rates imposed domestically on labor income - that is, it requires a limit on tax competition. However, any such limit must (as both a normative and a practical matter) be balanced against the desire of democratic countries to determine the size of their own public sectors.

This Article attempts first to describe the problems of tax competition and then to develop possible solutions that both are congruent with democratic principles and balance the developed countries' need to maintain their social safety nets with the developing countries' need to attract foreign capital. Part II describes in detail the ways in which international tax competition can lead to under-taxation of crossborder income from capital, as compared with the taxation of domestically invested capital in developed countries. It seeks to establish that both portfolio investment income and income from direct investment can be earned abroad largely free of tax. It then presents the available data on the magnitude of the resulting revenue losses.

Part III analyzes the problem of tax competition from a global normative perspective. Tax competition implicates three normative considerations: efficiency, equity, and democracy. From an efficiency perspective, tax competition impairs the optimal global allocation of investment; when the effective tax rate abroad is lower than the effective rate at home, taxpayers will prefer international investments over domestic investments that, but for the tax regime, would provide more efficient returns. From an equity perspective, if capital cannot be effectively taxed, the tax base will generally shift - regressively - toward labor. Thus, tax competition impairs the income tax's ability to redistribute wealth from the rich to the poor. 
These considerations weigh in favor of limiting tax competition. However, from the standpoint of democracy, each country should have the autonomy to determine the size of its public sector and the tax mix that finances it. Thus, Part III concludes by trying to define which forms of tax competition are acceptable when we balance the efficiency and equity arguments against democracy.

Part IV attempts to describe the costs and benefits of tax competition from the perspectives of developed and developing countries. For developed countries, tax competition makes it more difficult to finance the social safety net, which already faces increasing pressure from both demographic factors and the side effects of globalization. For developing countries, tax competition makes it difficult to maintain stable government revenues; foreign investments do not adequately offset that loss of revenue. Finally, Part IV attempts to analyze the effects of tax competition on inter-nation equity: it argues that we should give preference to the interests of developing countries as we choose among competing solutions to the tax competition problem.

Part V suggests possible solutions to the globalization dilemma. It first describes recent proposals by the European Union and the OECD to curb tax competition and argues that although they represent useful beginnings, because they are limited to member countries of the EU and OECD, they are insufficiently broad and therefore likely to be ineffective in the long run. Part V then seeks to develop alternative solutions, based on the coordinated imposition of withholding taxes by OECD countries where portfolio investment and the consumption of goods and services take place, in a way that adequately distinguishes between acceptable and unacceptable forms of tax competition.

\section{INTERNATIONAL TAX COMPETITION AND THE TAXATION OF CAPITAL}

\section{A. Taxation of Savings: Portfolio Exemptions, Traditional Tax Havens, and the Global Tax}

In I984, the United States unilaterally abolished its withholding tax of $30 \%$ on foreign residents who earned portfolio interest income from sources within the United States. ${ }^{4}$ "Portfolio interest" was defined to include interest on U.S. government bonds, on bonds issued by U.S. corporations (unless the bondholder held ten percent or more of the shares of the corporation), and on U.S. bank accounts and certificates

\footnotetext{
4 See Deficit Reduction Act of I 984 , Pub. L. No. 98-369, § 27 (a), 98 Stat. 494, 648-50 (codified as amended at I.R.C. $\$ 87 \mathrm{I}(\mathrm{h})(\mathrm{I} 994)$ ).
} 
of deposit.5 This "portfolio interest exemption" is available to any nonresident alien (that is, any person who is not a U.S. resident for tax purposes) and does not require any certification of identity or proof that the interest income was subject to tax in the investor's country of residence.

The portfolio interest exemption resulted from a fortuitous combination of three factors. First, the Reagan tax cuts of 1981 , which dramatically lowered the U.S. effective tax rate, ${ }^{6}$ and the accompanying defense buildup created a significant budgetary deficit that the U.S. government could finance only by borrowing abroad. Second, unlike other U.S. tax treaties with developed countries, which provide for zero withholding rates on interest paid from one treaty partner to the other, the Japan-U.S. tax treaty imposed a Io\% withholding tax.? Third, in 1987 , the United States decided to terminate its tax treaty with the Netherlands Antilles, which had a zero withholding rate on interest and no limitation on benefits to Antilles residents. ${ }^{8}$ By channeling the loans through a Netherlands Antilles finance subsidiary, U.S. corporations had been able to borrow abroad without having a withholding tax imposed on the interest. ${ }^{9}$ Thus, the portfolio interest exemption was motivated by the desire of both the U.S. government and U.S. multinationals to borrow abroad without having to bear the cost of any withholding tax, which, under the circumstances of 1987 , was likely to be shifted to the borrower.

Arguably, none of these reasons for the portfolio interest exemption is valid today. The U.S. government is in budgetary surplus, and Ja-

5 Id. Interest on loans made by foreign banks was excluded from the exemption to protect the competitive position of U.S. banks. See I.R.C. $\$ 88 \mathrm{I}(\mathrm{c})(3)(\mathrm{A})(\mathrm{I} 994)$. Interest on U.S. bank accounts received by foreigners is exempt. See id. $\$ 87 \mathrm{I}(\mathrm{i})$.

6 See Hans-Werner Sinn, Why Taxes Matter: Reagan's Accelerated Cost Recovery System and the U.S. Trade Deficit, I ECON. POL'Y 240, 246 (1985) (estimating that the adoption of ACRS resulted in a shift of between \$0.8 and \$I.I trillion of foreign investment into the United States).

7 See Convention for the Avoidance of Double Taxation and the Prevention of Fiscal Evasion with Respect to Taxes on Income, Mar. 8, I 97 I, U.S.-Japan, art. XIII, I 4, 23 U.S.T. $967,990$.

8 On June 29, I987, the United States officially notified the Netherlands Antilles of the termination of their bilateral income tax treaties, effective January I, 1988. See Andre Fogarasi, Richard Gordon, John Venuti \& Diane Renfroe, Current Status of U.S. Tax Treaties, 25 TAX MGMT. INT'L J. 523, 523 (1996). However, on July 10, 1987, the United States modified its notice of termination to provide that Article VIII (exempting interest paid by U.S. persons to corporations and residents of the Netherlands Antilles from U.S. tax) would continue in force. See id. The Treasury reached an agreement with the Antilles on a protocol to the limited income tax treaty, to take effect June 30 , 1996, that terminated the U.S. tax exemption on interest paid to Antilles companies that were not U.S.-owned (that is, not subsidiaries of U.S. companies), and to U.S.-owned Antilles companies both on non-Eurobond debt and on Eurobond debt issued after October I5, I984. See id. at 523-24.

9 See Charles I. Kingson with Cynthia A. Blum, International Taxation 29 (I998). 
pan is an unlikely source of funds. ${ }^{10}$ Moreover, given the size of the U.S. bond market and the widely held perception of U.S. bonds as relatively safe investments in turbulent economic times, both the U.S. government and U.S. corporations can probably afford to borrow abroad despite any withholding costs. ${ }^{11}$ However, the portfolio interest exemption remains with us. ${ }^{12}$

The United States's enactment of the portfolio interest exemption has resulted in a classic "race to the bottom." One after another, all the major economies have abolished their withholding taxes on interest for fear of losing mobile capital flows to the United States. ${ }^{13}$ Table I shows the I 993 withholding rates imposed by EU member countries and the United States on various forms of capital income (interest on bank accounts; interest on securities, specifically government and corporate bonds; and dividends) paid to foreign residents in the absence of a treaty..$^{14}$

TABLE I. WITHHOLDING TAXES ON INTEREST, I 993 (percentage rates)

\begin{tabular}{|l|c|c|c|}
\hline \multicolumn{1}{|c|}{ Country } & $\begin{array}{c}\text { Bank } \\
\text { accounts }\end{array}$ & Securities & Dividends \\
\hline Belgium & 0 & IO & I5 \\
\hline Denmark & 0 & 0 & I5 \\
\hline France & 0 & 0 & I5 \\
\hline Germany & 0 & 0 & I5 \\
\hline Greece & IO & IO & 0 \\
\hline Ireland & 0 & 0 & 0 \\
\hline Italy & IO & IO & I5 \\
\hline
\end{tabular}

10 If Japan were a possible source of funds, the tax treaty could be renegotiated to reduce the withholding rate on interest - especially given Japan's current desire to attract foreign investors. Interestingly, the reason this was not done in 1984 was probably the desire of Japanese investors to avoid being covered by the treaty's exchange-of-information article, which could have required them to reveal their unreported foreign source income.

11 See generally Clive Crook, The State of the World - Fragile but Euphoric, 3I NAT'L J. 86 (1999); J. Bradford DeLong, Should We Fear Deflation?, I BroOKINGS PAPERS ON ECON. ACTIVITY 225, 239-4I (William C. Brainard \& George L. Perry eds., I999).

12 Part $\mathrm{V}$ argues that the United States should abolish the exemption unilaterally, given recent EU developments. See infra pp. 1667-68.

13 The race may have begun earlier than 1984 , when the interest on U.S. bank deposits was taxfree and the Antilles treaty enabled U.S. borrowers to avoid withholding on their interest payments. See KINGSON WITH BLUM, supra note 9, at 229. But the symbolic significance of enacting the exemption gave the race a strong push forward, as the resulting capital flight from Latin America indicates. See infra pp. 1584-85.

14 See Vito TANZI, TAXation IN AN INTEgrating WORLD I3I tbl.8-4 (1995); see also Edward $\mathrm{H}$. Gardner, Taxes on Capital Income: A Survey, in TAX HaRMONIZATION IN THE EUROPEAN COMMUNITY 52, 60 (George Kopits ed., 1992) (providing similar but not identical figures). 


\begin{tabular}{||l|c|c|c|}
\hline Luxembourg & 0 & 0 & I5 \\
\hline Netherlands & 0 & 0 & I5 \\
\hline Portugal & I5 & I5 & I5 \\
\hline Spain & 0 & 0 & I5 \\
\hline United Kingdom & 0 & 0 & I5 \\
\hline United States & 0 & 0 & 30 \\
\hline
\end{tabular}

As the table indicates, most developed countries levy no withholding tax on interest paid to nonresidents on bank deposits and on government and corporate bonds. These nations do levy taxes on dividends, but dividends (unlike interest) are not deductible, and the underlying income has therefore already been taxed once. ${ }^{15}$ In reality, the discrepancy between interest and dividends may be smaller than the table indicates, for two reasons. First, a significant portion of the return on equity comes in the form of capital gains, which are not subject to source-based taxation in any of the countries included in the table. Second, the withholding tax on dividends is generally easy to avoid for sophisticated investors. For example, a foreign investor can construct a "total return equity swap" in which she receives payments equivalent to dividends from an investment banker in the source country, who in turn hedges by holding the underlying stock and receiving the actual dividends. Most countries do not subject the dividendequivalent payments to withholding, and the underlying dividends are free from withholding because they are paid to a domestic recipient. ${ }^{16}$ This situation has led to calls for a "portfolio dividends exemption."17

The standard economic advice to small, open economies is to avoid taxing capital income at its source, because the tax will be shifted forward to the borrowers and result in higher domestic interest rates. ${ }^{18}$

15 Moreover, even countries that integrate the corporate and shareholder taxes by giving shareholders a credit for corporate tax attributable to dividends (and most countries in Table I use this "imputation" method of integration) generally do not extend those credits to nonresidents. See, e.g., Hugh J. Ault, Corporate Integration, Tax Treaties and the Division of the International Tax Base: Principles and Practices, 47 TAX L. REV. 565, 585-86 (1992).

16 See Reuven Avi-Yonah \& Linda Swartz, Virtual Taxation: Source-Based Taxation in the Age of Derivatives, 2 DERIVATIVES 247, 248 (1997); Edmund S. Cohen, Individual International Tax Planning Employing Equity Derivatives, 4 DERIVATIVES 52, 54 (I998). For other techniques relying on the portfolio interest exemption, see Gregory May, Flying on Instruments: Synthetic Investments and Withholding Tax Avoidance, 73 TAX NOTES I 25 ( I996).

17 E.g., Yaron Z. Reich, Taxing Foreign Investors' Portfolio Investments: Developments and Discontinuities, 98 TAX NOTES TODAY I I4-7I, II I98-2 I I (1998), available in WL 98 TNT I1471 .

18 See, e.g., JACOB A. FRENKEL, ASSAF RAZIN \& EFRAIM SADKA, INTERNATIONAL TAXATION IN AN INTEGRATED WORLD 203-07, $214-16$ (I99I); see also id. at 206 ("We can conclude therefore that no capital-income tax whatsoever is imposed . . . if capital flight to the rest of the world cannot be effectively stopped."). For further discussion of this advice and its implications, see Part IV below. 
However, the countries in Table I include several large economies (the United States, Germany, and the United Kingdom) in which the tax would not necessarily be shifted forward, but which refrain from imposing withholding taxes primarily out of fear that capital would otherwise move swiftly to other locations that do not impose a withholding tax. Thus, the Ruding Committee, writing about the European Community, concluded in 1992 that "recent experience suggests that any attempt by the EC to impose withholding taxes on cross-border interest flows could result in a flight of financial capital to non-EC countries." 19

Germany is a case in point: In 1988 , its government introduced a relatively low 10\% withholding tax on interest on bank deposits but had to abolish it within a few months because of the magnitude of capital flight to Luxembourg. ${ }^{20}$ In I99I, the German Federal Constitutional Court held that withholding taxes on wages but not on interest violated the constitutional right to equality; the government was therefore obliged to reintroduce the withholding tax on interest, but it exempted nonresidents. ${ }^{21}$ "Nonresidents" may, however, be German residents investing through Luxembourg bank accounts and benefiting from the Luxembourg tradition of bank secrecy. ${ }^{22}$

The current situation resembles a multiple-player assurance ("stag hunt") game: all developed countries would benefit if all re-introduced the withholding tax on interest because they would gain revenue without the risk that the capital would be shifted to another developed country. However, no country is willing to attempt to spark cooperation by imposing a withholding tax unilaterally; thus, they all "defect" (that is, refrain from imposing the tax) to the detriment of all. ${ }^{23}$

In global terms, this outcome would make no difference if countries were able to tax their residents on foreign source interest and dividend income as a portion of all income "from whatever source derived."24 However, as Joel Slemrod writes, "although it is not desirable to tax capital on a source basis, it is not administratively feasible to tax capi-

19 COMMISSION OF THE EUROPEAN COMMUNITIES, REPORT OF THE COMMITTEE OF INDEPENDENT EXPERTS ON COMPANY TAXATION 201 (I992) [hereinafter RUDING REPORT].

20 See Leif Mutén, International Experience of How Taxes Influence the Movement of Private Capital, 8 TAX NOTES INT'L 743, 745-46 (1994).

21 See id.

22 See Suzanne McGee, Tax Inquiry Turns Banking Grayer in Luxembourg, WaLl ST. J., July 20, 1999, at $\mathrm{C}_{1}$ (discussing German government investigations of German residents' accounts in Luxembourg banks); Sleepless in Frankfurt, Again, ECONOMIST, June 20, 1 998, at 87-88 (same).

23 The assurance game differs from the more familiar prisoner's dilemma in that the preferred outcome for each player is mutual cooperation rather than defection from cooperation. See Amir N. Licht, Games Commissions Play: $2 x 2$ Games of International Securities Regulation, 24 YALE J. INT'L L. 6I, I I 2-I 3 (I 999); see also MiChaEL TAYLOR, THE POSSIBILITY OF COOPERATION I8-I 9 (I987).

24 I.R.C. \$ 6 I (I 994$)$. 
tal on a residence basis, $" 25$ because residence-country fiscal authorities generally have no means of learning about the income that their residents earn abroad. Even though tax treaties contain an exchange-ofinformation procedure, it is fundamentally flawed in two respects. First, the lack of any uniform, worldwide system of tax identification numbers means that most tax administrations are unable to match the information they receive from their treaty partners with particular domestic taxpayers. Second, there are no tax treaties with traditional tax havens, ${ }^{26}$ and routing the income through a tax haven suffices to block the exchange of information. For example, if a Mexican national invests in a U.S. bank through a Cayman Islands corporation, the Mexican authorities would gain nothing from the exchange-ofinformation article in the U.S.-Mexico tax treaty; given the Caymans, bank secrecy, the American IRS would have no way of knowing that the portfolio interest paid to the Caymans was beneficially owned by a Mexican resident covered by the treaty. ${ }^{27}$

Even in the case of sophisticated tax administrations like the IRS, tax compliance substantially depends upon either withholding at the source or information reporting. When neither is available, as in the case of foreign source income, compliance rates drop dramatically. ${ }^{28}$

The result is that much of the income from overseas portfolio investments escapes income taxation by either source or residence countries. Latin American countries provide a prime example: after the enactment of the portfolio interest exemption, about $\$ 300$ billion fled from Latin American countries to bank accounts and other forms of

\footnotetext{
25 Joel Slemrod, Comments, in TANZI, supra note I4, at I4I, 144.

26 "Traditional" tax havens are countries with a low tax rate and bank secrecy laws that protect depositors' identities. For an attempt at definition, see ORGANIZATION FOR ECON. COOPERATION AND DEV., HARMful TAX COMPETITION: AN EMERGING GLOBAL ISSUE 2 I-25 (1998) [hereinafter OECD REPORT]. By contrast, "production" and "headquarters" tax havens have generally high tax rates that provide specific tax exemptions to foreigners; section II.B discusses the latter types. See infra pp. 1586-97.

27 See generally TANZI, supra note $\mathrm{I}_{4}$, at 78-89. The United States has negotiated exchange-ofinformation agreements with several Caribbean countries in an attempt to overcome this problem. See Bruce Zagaris, OECD Report on Harmful Tax Competition: Strategic Implications for Caribbean Offshore Jurisdictions, 98 WORLDWIDE TAX DAILY 220-I 7 (1998), available in WL 98 TNI 220-I 7. However, because one holdout is sufficient to provide a haven, these efforts have thus far been futile.

28 See Internal ReVEnue SERV,, U.S. DEP'T OF THE TREasury, InCOME TAX COMPLIANCE RESEARCH: GROSS TAX GAP Estimates AND PROJECTIONS FOR 1973-1992, PUB. 7285, at 6 (I988). Charles McLure estimates that Germany taxes only about to to $20 \%$ of foreign source interest income. See Charles E. McLure, Jr., Remarks at the VIIIth Munich Symposium on International Taxation (I989), reprinted in MUNICH SYMPOSIUM ON INT'L TAXATION, INFLUENCE OF TAX DIFFERENTIALS ON INTERNATIONAL COMPETITIVENESS 55 (I990) [hereinafter MUNICH SYMPOSIUM].
} 
portfolio investment in the United States. ${ }^{29}$ Most of these funds were channeled though tax-haven corporations and therefore escaped taxation in the country of residence. Estimates of the capital flight from all developing countries to the United States in the 1980s range as high as $\$ 148$ billion in a single year. ${ }^{30}$

Nor is the problem limited to developing countries. Much of the German portfolio interest exemption benefits German residents who maintain bank accounts in Luxembourg, and much of the U.S. portfolio interest exemption benefits Japanese residents who hold U.S. Treasuries and do not report the income in Japan. ${ }^{31}$ It is questionable how much tax even the United States actually collects on portfolio income that its residents earn abroad other than through mutual funds. One estimate puts capital flight from the United States between 1980 and 1982 as high as $\$ 250$ billion. ${ }^{32}$

Thus, in the absence of withholding taxes or effective information exchange, income from foreign portfolio investments frequently escapes being taxed by any jurisdiction. This immunity from taxation is particularly significant because the flows of portfolio capital across international borders have been growing much faster than either world gross domestic product or foreign direct investment (FDI). ${ }^{33}$ Current

29 See Chander Kant, Foreign Direct Investment and CaPital Flight i (Princeton Studies in Int'l Fin. No. 80, 1996); Charles E. McLure, Jr., U.S. Tax Laws and Capital Flight from Latin America, 20 U. MIAMI INTER-AM. L. REV. 321, 349-50 (1989) [hereinafter McLure, Capital Flight from Latin America]. McLure writes: "I must admit that, as Deputy Assistant Secretary of the Treasury at the time this action [the adoption of the portfolio interest exemption] was taken, I did not fight early enough, long enough, or hard enough against its enactment," mostly because of the effect on Latin American countries. Charles E. McLure, Jr., International Considerations in United States Tax Reform, in MUNICH SYMPOSIUM, supra note 28 , at I, 9 \& n. I 2 [hereinafter McLure, International Considerations]. It is interesting that these estimates were so high, considering that investing in some forms of U.S. holding (such as bank accounts or investment through the Netherlands Antilles) was possible even prior to 1984. Apparently, the portfolio interest exemption made a significant difference. In any case, the results hold regardless of when the practical abolition of withholding took place.

30 See KANT, supra note 29 , at 2 I tbl.3.

31 See Hiroshi Oda \& Masabumi Yamane, Japan, in BUTTERWORTHS INTERNATIONAL GUIDE To MONEY LaUnderING 109, I 10 (Richard Parlour ed, I995); Tony Barber, Germans Find Tax Evasion Good Sport, FIN. TIMES (London), June 19, 1999, at 3; Mark Milner, Dresdner Tax Arrests, GUARDIAN (London), Jan. 4, I996, at 15.

32 See Michael Dooley, Comment, in CaPITAL Flight AND THIRD WORLd DEBT 79, 79 (Donald R. Lessard \& John Williamson eds., I987).

33 Foreign direct investment (FDI) out of the United States grew from $\$ 396$ billion in 1980 to $\$ 1.024$ trillion in 1997 , while outbound portfolio investment grew from $\$ 62$ billion in 1980 to $\$ 1.446$ trillion in I 997 . Similarly, FDI into the United States grew from $\$$ I 26 billion in I 980 to $\$ 752$ billion in 1997 , while inbound foreign portfolio investment grew from $\$ 90$ billion to $\$ 2.2$ trillion in the same period. See NATIONAL FOREIGN TRADE COUNCIL, THE NFTC FOREIGN INCOME Project: INTERNational TAX POlicy For the 2ist CENTURY, PART ONE: A RECONSIDERATION OF SUBPART F III 34, 4 I (I999) [hereinafter NFTC PROJECT], reprinted in NFTC Releases Subpart F Report, I 999 TAX NOTES TODAY 58-I 7 , available in WL I999 TNT 58I7; Russell B. Scholl, U.S. Dep't of Commerce, The International Investment Position of the 
estimates indicate that international capital flows amount to $\$ \mathrm{I}$ trillion per day. Although this figure is much larger than income from capital, it gives a sense of the magnitudes at stake. ${ }^{34}$

This situation has led such knowledgeable observers as Richard Bird to write that the weakness of international taxation calls into question the income tax's "very rationale" and renders its future "far from bright." 35 . In section II.C, I try to assess the possible revenue losses from portfolio investment abroad to determine whether they really amount to a threat to the income tax. In Part V, I consider possible solutions.

\section{B. Taxation of Multinationals: Permanent Establishments and Headquarters and Production Tax Havens}

Three types of jurisdictions may, under currently accepted rules, impose a corporate income tax on income from the sale of goods or provision of services across national borders: the demand jurisdiction, the supply jurisdiction, and the residence jurisdiction. The demand jurisdiction (where consumption of the goods or services takes place) may impose a tax if the goods or services are provided through a "permanent establishment" (which need only consist of some physical presence in the demand jurisdiction). ${ }^{36}$ The supply jurisdiction (where

United States in 1997, SURVEY OF CURRENT BUSINESS, July 1998, 24, 32 tbl. I. In light of these numbers, the literature that suggests that capital is immobile internationally is puzzling. For a sample of that literature, see Martin Feldstein \& Charles Horioka, Domestic Saving and International Capital Flows, 90 ECON. J. 314 (1980). For an explanation of capital immobility in terms of information asymmetry, see Roger H. Gordon \& A. Lans Bovenberg, Why Is Capital So Immobile Internationally? Possible Explanations and Implications for Capital Income Taxation, 86 AM. ECON. REV. 1057, 1059-73 (I996), and for an extension of that argument that derives implications for optimal tax policy, see Assaf Razin, Efraim Sadka \& Chi-Wa Yuen, Tax Principles and Capital Inflows: Is It Efficient to Tax Nonresident Income? (Mar. 1996) (unpublished National Bureau of Econ. Research Working Paper No. 5513, on file with the Harvard Law School Library). For a recent review of the evidence and an argument that Feldstein and Horioka may have been wrong in 1980 and are probably wrong today, see Michael P. Devereux, Investment, Saving, and Taxation in an Open Economy, I2 OXFORD REV. ECON. POL'Y 90, 91-I06 (1996).

34 See Erik R. Peterson, Looming Collision of Capitalisms?, WASH. Q., Spring 1994, at 65, 66 (estimating that daily global capital movements increased to well over \$I trillion by I992); Peter D. Sutherland, Sharing the Bounty, BANKER, Nov. 1998, at I6 (estimating that average daily foreign exchange transactions grew from $\$ I_{5}$ billion in 1973 to $\$ I .2$ trillion in I 995 and that international capital flows now exceed trade flows by a ratio of 60 to $\mathrm{I}$ ).

35 Richard M. Bird, Shaping a New International Tax Order, 42 BULL. FOR INT'L FISCAL DoCUMENTATION 292, 293, 299 (I 988); see also Roger H. Gordon, Can Capital Income Taxes Survive in Open Economies?, 47 J. FIN. I159 (1992); Jack Mintz, Is There a Future for Capital Income Taxation?, 42 CANADIAN TAX J. 4469 (1994). See generally Charles E. McLure Jr., Tax Policies for the 2 ist Century, Keynote Address to the 5 oth Congress of the International Fiscal Association, Geneva (Sept. I-6, 1996) (on file with the Harvard Law School Library) [hereinafter McLure, Keynote Address].

36 If the goods or services are provided through a subsidiary with a permanent establishment, the demand jurisdiction may also impose a tax on the income attributable thereto. 
production of the goods or services takes place) may impose a tax on the income attributable to such production. In addition, the residence jurisdiction (where the corporation is incorporated or managed and controlled) has a residual right to tax income that is not taxed at the source of either demand or supply.

The argument of this section can be summarized as follows: Under currently accepted rules, the jurisdiction most likely of the three to want to tax multinationals on income derived therein, the demand jurisdiction, lacks the right to tax such income in an increasing number of cases. The jurisdictions that do have that right, the supply and residence jurisdictions, are unlikely to want to do so because of tax competition. Thus, much of the income earned by multinationals from cross-border transactions is likely to escape the income tax altogether.

I. Demand Jurisdictions and the Permanent Establishment Threshold. - Demand jurisdictions, especially those that can attract corporations with large consumer markets, are most likely to impose significant tax rates on both domestic and foreign corporations. Under the current international tax regime, as embodied in the tax treaty network, a seller is taxable in a demand jurisdiction only if it has a physical presence therein. The physical presence test can be satisfied by either a "permanent establishment" or, in U.S. terms, a "trade or business within the United States." ${ }^{37}$ Most often, the physical presence takes the form of a branch or subsidiary of the corporation. ${ }^{38}$

Traditionally, multinationals had to establish such a physical presence in demand jurisdictions to gain a significant market share or to avoid tariff barriers. However, the tariff barriers have all but disappeared because of the GATT/WTO tariff reductions, and the rise of electronic commerce has made selling large quantities of goods or services into a demand jurisdiction without establishing a physical presence there increasingly feasible. ${ }^{39}$ Therefore, although multinationals currently pay some tax in demand jurisdictions in which they have subsidiaries engaged in distribution, the limited tax base they provide is rapidly diminishing in the face of technological developments. Governments cannot rely on receiving revenue from such cor-

37 I.R.C. \$ 864(b) (1994 \& Supp. III 1997).

38 See Avi-Yonah, International Taxation of Electronic Commerce, supra note 40 , at 535

39 Most authoritative discussions of taxation of electronic commerce conclude that the most common forms of such commerce (a web page or even a server located in a jurisdiction) do not amount to permanent establishments and thus do not meet the taxing threshold of the demand jurisdiction. See OfFICE OF TAX POLICY, U.S. DEP'T OF THE TREASURY, SELECTED TAX POLICY IMPLICATIONS OF GLOBAL ELECTRONIC COMMERCE I (1996), available at <http://www.ustreas. gov/taxpolicy/internet.pdf $>$. 
porations in the future if the permanent-establishment requirement remains unchanged. 40

2. Supply Jurisdictions and Production Tax Havens. - Because of the coincidence between production and consumption in the developed world, most supply jurisdictions, no less than (and often the same as) demand jurisdictions, imposed significant income tax rates on both domestic and foreign corporations. However, a crucial development in the last decade or so has been the increasing prevalence of production tax havens. A production tax haven is a jurisdiction that grants a tax holiday to foreign production facilities located therein, but still levies an income tax on domestic corporations and individual residents. This type of haven differs from the traditional offshore tax haven, which has no corporate income tax (and sometimes no significant tax at all). This distinction is crucial because it means that a foreign investor in a production tax haven can enjoy the benefits of government services, which the government finances by taxing relatively immobile factors of production such as labor and land, while the investor itself pays little or no corporate income tax.

Tax competition has led to the proliferation of production tax havens. Currently, at least 103 countries offer special tax concessions to foreign corporations that set up production or administrative facilities within their borders. ${ }^{41}$ They include such developed countries such as Belgium, Ireland, and Israel and such developing countries as Malaysia and India. The extent of the tax holiday varies, but in general, the tax haven reduces its statutory tax rate to Io\% or less for foreign corporations investing in specified types of facilities or areas within the jurisdiction. However, the jurisdiction imposes a higher tax rate of between $30 \%$ and $40 \%{ }^{42}$ on local corporations, a personal income tax at even higher rates on resident individuals, and a VAT. ${ }^{43}$

Studies by economists have shown that such tax incentives are quite widespread and that investments in these countries are significant. For example, Altshuler and Newlon have studied the I 986 tax returns of $6 \mathrm{I} 7$ U.S. multinational enterprises (MNEs) and report that out of 1827 foreign subsidiaries ("controlled foreign corporations," or CFCs) of such multinationals, 659 were located in countries with a tax

40 For a fuller exposition of this theme, see Reuven S. Avi-Yonah, International Taxation of Electronic Commerce, 52 TAX L. REV. 507, 507-23 (I997) [hereinafter Avi-Yonah, International Taxation of Electronic Commerce]. For proposals to change the definition of "permanent establishment" to permit taxation without a physical presence, see section V.C.2 below.

41 See VERNON, supra note I, at 32 tbl.2-I (citing UNITED NATIONS, supra note I, at tbl.III.2).

42 A rate between $30 \%$ and $40 \%$ is within the normal range for OECD members.

43 See generally PRICEWATERHOUSECOOPERS, INDIVIDUAL TAXES I998: WORLDWIDE SUMMARIES (I998) (listing income tax and VAT rates). 
rate below $20 \% .44$ These CFCs had assets of $\$ 5 \mathrm{I}$ billion and earnings of $\$ 5.2$ billion in 1986 , which represented over $40 \%$ of the total assets and earnings of all the CFCs. ${ }^{45}$ Similarly, Hines and Rice have documented the extent of U.S. investment in forty-one foreign tax havens for 1982.46 They show that while the havens had only I.2\% of world population and $3.0 \%$ of world GDP, their share of the foreign operations of U.S. MNEs was $26 \%$ of assets, $21.4 \%$ of equity, and $30.6 \%$ of net income (but only $4.3 \%$ of employment and $4.2 \%$ of property, plant, and equipment). ${ }^{47}$

Two specific examples may help to illustrate this phenomenon. Intel Corporation, a top-ten multinational, has operations in more than thirty countries around the globe. The company states: "An Intel chip developed at a design center in Oregon, might be manufactured at a wafer fabrication facility in Ireland, packaged and tested in Malaysia, and then sold to a customer in Australia. Another chip might be designed in Japan, fabricated in Israel, packaged and tested in Arizona, and sold in China."48 Specifically, Intel has major manufacturing facilities in Puerto Rico, China, Malaysia, the Philippines, Ireland, and Israel $^{49}$ - all jurisdictions that grant tax holidays..$^{50}$

This phenomenon is not confined to high-tech corporations like Intel. For example, the eight General Motors car assembly plants built since 1990 are located in Brazil, Argentina, Mexico, Poland, Thailand,

44 See Rosanne Altshuler \& T. Scott Newlon, The Effects of U.S. Tax Policy on the Income Repatriation Patterns of U.S. Multinational Corporations, in STUDIES IN INTERNATIONAL TAXATION 72, 89, 92, 93 tbl.3.3 (Alberto Giovannini, R. Glenn Hubbard \& Joel Slemrod eds., 1993).

45 See id. at 93 tbl.3.3.

46 See James R. Hines, Jr., \& Eric M. Rice, Fiscal Paradise: Foreign Tax Havens and American Business, Iog Q.J. ECON. I49, I50-53 (1994).

47 See id. at 152 tbl.I. The share of net income in the havens is much higher than that reported for continental Europe (14.8\%), which has $10.7 \%$ of world population and $34.5 \%$ of world GDP. See id.

48 <http://www.intel.com/intel/intelis/sites.htm> (visited Feb. I, I 999).

49 See Intel Corp., Annual Report Pursuant to Section 13 or 15 (d) of the Securities Exchange Act of I934 for the Fiscal Year Ended December 26, I998 (Form IO-K), File No. 0-62I7, at 5, available at http://www.sec.gov/Archives/edgar/data/50863/0001047469-99-0I1450.txt [hereinafter Intel IO-K].

50 Intel has sales facilities in high-tax demand jurisdictions such as Japan, Germany, and the United Kingdom. But the German office's mere existence does not allow Germany to tax Intel on chips sold in Europe; it all depends on whether the income can be attributed to the office in Germany, which it cannot be if the sale is negotiated and concluded elsewhere. Intel's tax liability is further reduced if, through electronic commerce, Intel can eliminate the need for such permanent establishments as the German office. In recent ads, Intel has boasted of selling over \$I billion worth of chips in electronic commerce. 
India, Indonesia, and China. ${ }^{51}$ Except for Mexico, all of these nations are production tax havens. ${ }^{52}$

The rise of electronic commerce is likely to make it easier to locate production facilities in tax havens. The Intel example, which involves traditional, nondigitizable goods, is a case in point: Modern communication technology has enabled Intel to coordinate production across the globe and to locate its production facilities in such production tax havens as Malaysia. ${ }^{53}$ When goods can be conveyed in digital form, such as software, locating the entire operation in a tax haven is even easier: the software can be written anywhere ${ }^{54}$ and transmitted elsewhere over secure corporate intranets. Information services in general have no inherent source; accordingly, online pornography, still one of the most profitable types of electronic commerce, is run largely from Guyana for both regulatory and tax-related reasons. ${ }^{55}$

Are corporate decisions about where to locate influenced by the tax regime in the host country? Economists have conducted several studies examining the importance of tax differentials in location decisions. James Hines has recently summarized ten quantitative studies of U.S. direct investment abroad and ten quantitative studies of foreign direct investment in the United States. He concludes that although taxes are not the only determinant of the location of investments, "[t]he answer that emerges in a variety of contexts and from a variety of approaches is that, in spite of all the other economic and political considerations that are clearly very important, taxation exerts a significant effect on the magnitude and location of FDI." 56 Hines estimates that the studies are generally consistent with a -0.5 elasticity of investment with respect to current tax rates. ${ }^{57}$ Peter. Wilson has corroborated these statis-

51 See Robyn Meredith, The Brave New World of General Motors, N.Y. TIMES, Oct. 26, I 997 $\S 3$, at $\mathbf{I}$.

52 The Mexican site benefits from the North American Free Trade Agreement.

53 Intel's I998 ro-K states that an interruption in air traffic between the United States and Intel's overseas locations would have a material adverse effect on its operations. See Intel Io-K, supra note 49 , at 5 . This problem would not occur for digitizable goods.

54 For example, much such software is written in India or Israel, where Microsoft has major operations. See Microsoft Worldwide Sites - Links to Office Contact Information \& Worldwide Web Sites <http://www.microsoft.com/worldwide> (visited Feb. 23, 2000).

55 See David R. Tillinghast, Comments on Professor Peroni's Paper on Reform of the U.S. International Income Tax Rules, 5 I U. MIAMI L. REV. IOI3, IOI4 (1997).

56 James R. Hines, Jr., Tax Policy and the Activities of Multinational Corporations, in FISCAL POLICY: LESSONS FROM ECONOMIC RESEARCH 40I, 4I 4-I 5 (Alan J. Auerbach ed., I 997) [hereinafter Hines, Tax Policy]; see also James R. Hines, Jr., Lessons from Behavioral Responses to International Taxation, 52 NAT'L TAX J. 305, 308-I9 (I999) (exploring the empirical evidence that international tax regimes affect individualized corporate behavior).

57 See Hines, Tax Policy, supra note 56, at 4I5; see also Michael P. Devereux \& Rachel Griffith, Taxes and the Location of Production: Evidence from a Panel of U.S. Multinationals, 68 J. PUB. ECON. 335, 362-63 ( 1998 ) (concluding, on the basis of a study of 1632 U.S. multinationals and 
tical findings in his interviews with managers from nine firms regarding sixty-eight location decisions. 58 He concludes that "tax considerations largely dictate location decisions for business activities ... such as administrative and distribution centers." 59 As for production locations, he finds that taxes are an important consideration in the location decision, although they rarely dominate the decision process. ${ }^{60}$

Studies have also demonstrated multinationals' ability to shift profits to low-tax jurisdictions through transfer pricing or thin capitalization. For example, David Harris and his colleagues conclude, on the basis of data from 200 U.S. manufacturing firms for the period from 1984 to 1988 , that having a subsidiary in Ireland or in one of the Asian "tigers" (Taiwan, South Korea, Singapore, and Hong Kong) all jurisdictions offering tax holidays for foreign investors - is associated with lower U.S. taxes as a fraction of U.S. assets or U.S. sales "in a way that is consistent with tax-motivated income shifting." ${ }^{1}$ James Hines has surveyed several studies on the financial behavior of multinationals, including the use of debt and transfer pricing, and concludes that " $t]$ he evidence indicates that the financial behavior of multinational corporations is quite sensitive to tax considerations, though not completely determined by them."62

Some recent studies based on data from U.S.-based multinationals tend to bolster the view that tax competition has driven effective tax rates down, and that this competition has made U.S. investment abroad more sensitive to tax rates. Rosanne Altshuler, Harry Grubert, and Scott Newlon used U.S. Treasury data from corporate tax returns between 1984 and 1992 to assess the accuracy of these two contentions for manufacturing affiliates of U.S.-based multinationals. ${ }^{63}$ They find

where in Europe they decided to invest from 1980 to 1994 , that average effective tax rates similarly affected these decisions).

58 See G. Peter Wilson, The Role of Taxes in Location and Sourcing Decisions, in STUDIES IN INTERNATIONAL. TAXATION, supra note 44 , at 195 .

59 Id. at 229.

60 See id. In general, as I argue below, taxes are usually not the dominant factor affecting real investment decisions but can be determinative at the margin in the choice between two locations that are otherwise equally attractive. See infra p. I644.

61 David Harris, Randall Morck, Joel Slemrod \& Bernard Yeung, Income Shifting in U.S. Multinational Corporations, in STUDIES IN INTERNATIONAL TAXATION, supra note 44, at 277, 301 .

62 Hines, Tax Policy, supra note 56, at 430-31.

63 See Rosanne Altshuler, Harry Grubert \& T. Scott Newlon, Has U.S. Investment Abroad Become More Sensitive to Tax Rates? (Nov. I 997) (unpublished manuscript presented at National Bureau of Econ. Research Int'l Taxation Conference, Nov. 14, 1997, on file with the Harvard Law School Library). The authors calculate the average effective tax rates for foreign subsidiaries in about 60 countries by dividing total income taxes paid by their total earnings and profits (a measure defined by the Internal Revenue Code that approximates "book" income). See id. at 8 . As the authors note, this measure is much better than theoretical calculations of either marginal effective tax rates or average effective tax rates because such calculations make numerous assumptions and 
that average effective tax rates in manufacturing fell by more than I5\% between 1984 and $1992 .{ }^{64}$ The statutory tax rates likewise fell by $14 \%$, indicating that base-broadening measures did not offset rate reductions. The authors also find that manufacturing firms may have been more sensitive in this period in deciding where to locate their real manufacturing capital. ${ }^{65}$ Their hypothesis holds when countries with populations of less than one million, a category that includes most traditional tax havens, are excluded from the calculations. ${ }^{66}$ The authors conclude that their results are "consistent with increasing international mobility of capital and globalization of production." 67

Whether the tax competition phenomenon is desirable will be considered in Part III below. It is important, however, to note that an investing multinational faces no additional cost by choosing a low-tax jurisdiction - in contrast to the standard Tieboutian paradigm of tax competition in the state and local context, in which individuals choose jurisdictions based on their preferred levels of government services and bear the cost of reduced services if they choose a lower-tax jurisdiction. ${ }^{68}$ Here, the level of services provided by the host country is fixed before the tax holiday and is based on the revenues that were collected without regard to the tax holiday. Typically, the holiday jurisdiction tries to provide the same level of services with the tax holiday in place, replacing the revenue needed by increasing taxes on relatively immobile factors of production (chiefly land and labor). The tax holiday thus represents a pure windfall to a multinational that can choose among several jurisdictions with similar levels of government services but different tax rates.

use only rough approximations of country tax regimes. See id. at ro- II. In addition, Treasury data is superior to publicly available data because precise numbers are available for each CFC.

64 See id. at II.

65 See id. at 18.

66 See id. at 17 .

67 Id. at 18 . A recent study by Harry Grubert examines the evidence of tax competition and U.S. multinationals' response thereto based on U.S. Treasury data for 1984 and I992. See Harry Grubert, Tax Planning by Companies and Tax Competition by Governments: Is There Evidence of Changes in Behavior? (Nov. I 997) (unpublished manuscript presented at National Bureau of Econ. Research Int'l Taxation Conference, Nov. 15, I 997, on file with the Harvard Law School Library). He finds that the mean average effective tax rate fell by almost $10 \%$ from 1984 to 1992 , but that there was no notable convergence in tax rates. See id. at 17 . Grubert interprets this as suggesting that there was no tax competition, see id. at 18 , but his conclusion does not follow from the data: it is possible that countries with high tax rates in 1984 reduced them because of competition with countries with low tax rates, but that the low-tax countries responded with further decreases, resulting in a lower average rate overall but no convergence. Grubert also notes that there was no convergence in the European Economic Community, see id. at 18, 21, which contradicts the findings of the Ruding committee, see F. VANISTENDAEL \& MALCOLM GaMMIE, THE RUding COMMITTEE REPORT ON EUROPEAN CORPORATE TAX HARMONISATION (I 992).

68 See Charles M. Tiebout, A Pure Theory of Local Expenditures, 64 J. POL. ECON. 4I6, 4 I8 (1956). 
3. Corporate Residence Jurisdictions and Headquarters Tax Havens. - When the source country refrains from exercising its right to tax (which it commonly does for the reasons described above), the corporate residence jurisdiction can exercise its right to residual taxation. However, this subsection argues that corporate residence jurisdictions are unlikely actually to impose a çurrent tax on the foreign source active business income earned by multinationals whose headquarters are located (or whose parent corporations are incorporated) therein, for fear of driving those multinationals to reincorporate in headquarters tax havens.

Most corporate residence jurisdictions either exempt their multinationals' foreign source active business income from taxation ("exemption") or permit their multinationals to avoid paying tax on the income earned by their foreign subsidiaries until the income is actually repatriated to the parent in the form of dividends or otherwise ("deferral"). For example, under current U.S. rules ("Subpart F"), deferral applies to active business income earned by subsidiaries of U.S. parent corporations abroad. ${ }^{69}$ Significantly, deferral does not depend on whether the income was taxed abroad. Under deferral, a U.S.-based multinational can avoid paying taxes indefinitely on its active foreign source income as long as it does not need to repatriate it. ${ }^{70}$

The obvious solution to this problem would be to repeal deferral, that is, to apply Subpart $F$ to all income rather than limiting it to mostly passive income, as the Kennedy administration originally sug-

69 See I.R.C. 8895 I-960 (I994 \& Supp. IV I 998).

70 In the I980s, U.S. multinationals like GM were forced to repatriate profits because their U.S. revenues were too low to sustain their dividend payouts to shareholders, but that need for revenues may no longer be present. But see James R. Hines, Jr., \& R. Glenn Hubbard, Coming Home to America: Dividend Repatriations by U.S. Multinationals, in TAXATION IN THE GLOBAL ECONOMY I6I, I84 tbl.5.6 (Assaf Razin \& Joel Slemrod eds., I990).

Under the well-known Cary Brown formula, deferral is equivalent to exemption of the yield on the amount deferred. See, e.g., E. Cary Brown, Business-Income Taxation and Investment Incentives, in INCOME, EMPLOYMENT AND PUBLIC POLICY: ESSAYS IN HONOR OF ALVIN H. HANSON (1948). Thus, the income earned on foreign source profits of U.S. multinationals becomes exempt from U.S. tax. See David G. Hartman, Tax Policy and Foreign Direct Investment, $26 \mathrm{~J}$. PUB. ECON. 107, II6 (1985). Hartman argues that the tax on repatriation is unavoidable and therefore that deferral of foreign source earnings makes no difference in terms of ultimate after-tax yield. He concludes that FDI out of the reinvested earnings of foreign subsidiaries is unaffected by home-country taxes. See id. at 116 . For example, if the parent's tax rate is $30 \%$ and interest on earnings is $10 \%$, 100 earned abroad and repatriated would be subject to tax of 30 , leaving 70 , which would grow to 77 in the following year; if the 100 were left abroad, it would grow to 110 and be subject to tax of 33 when repatriated, likewise leaving 77. But Hartman assumes that there are no other domestic taxes except the tax on dividends. If, more realistically, there were a tax of $30 \%$ on the 7 of interest income in the first case, it would leave the taxpayer only 74.9 , while in the second case, the full 77 represents after-tax income, meaning that the yield is exempt.

Another way of stating the advantage of deferral is that if deferral lasts long enough, the present value of any tax imposed when the income is eventually repatriated approaches zero. 
gested in $196 \mathrm{I} .^{71}$ This solution has been repeatedly suggested by various administrations, incorporated in several recent legislative proposals, and endorsed by academic commentators. ${ }^{72}$ But it has never gotten off the ground; in fact, the recent trend has been in the opposite direction. Code $\S 956 \mathrm{~A}$, which limited the ability of multinationals to avoid repatriation by imposing current taxation rates on excess passive assets held abroad, was repealed in 1996,73 and the extension of "check-the-box" to foreign entities generally allows U.S. multinationals to elect deferral regardless of the entity's foreign legal status as a corporation or otherwise. ${ }^{74}$

How has deferral been so successfully maintained against all criticism, and why have other jurisdictions maintained an exemption for foreign source active business income? Consider what would happen if the United States were to end deferral. Parent corporations of new multinationals, especially in new industries like electronic commerce, would be less likely to incorporate in the United States. ${ }^{75}$ Instead, they would prefer to incorporate in countries that do not tax holding corporations, such as Belgium. ${ }^{76}$

Roger Gordon and Jeffrey MacKie-Mason have shown that firms' decisions whether to incorporate are significantly affected by tax considerations. ${ }^{77}$ Similarly, the decision where to incorporate can be influ-

71 See Special Message to the Congress on Taxation, PUB. PAPERS 290, 294-97 (Apr. 20, 1 96r).

72 For discussions of various proposals to abolish deferral, see Daniel J. Frisch, The Economics of International Tax Policy: Some Old and New Approaches, 47 TAx NoTES 581 (I990); Jane G. Gravelle, Foreign Tax Provisions of the American Jobs Act of 1996, 72 TAX NoTES I I65 (I996); and Peter Merrill \& Carol Dunahoo, 'Runaway Plant' Legislation: Rhetoric and Reality, 72 TAX NOTES 22 I (1996).

73 See I.R.C. \& 956A (1994), repealed by Small Business Job Protection Act of I 996, Pub. L. No. I04-I 88, § I5OI(a)(2), I IO Stat. I 755, I825.

74 See, e.g., Robert J. Peroni, Back to the Future: A Path to Progressive Reform of the U.S. International Income Tax Rules, 5I U. MIAMI L. REV. 975, 987-88 (I997) (noting that the check-thebox rules create an "essentially elective deferred system"); see also Reuven S. Avi-Yonah, To End Deferral as We Know It: Simplification Potential of Check-the-Box, 74 TAX NOTES 219, 2 I9-20 (1997) (same). In recent years, Congress has also expanded deferral by, for example, eliminating the CFC/PFIC overlap and by limiting the application of Subpart $F$ to the securities and insurance industries. See I.R.C. $\$ \S 95$ I(f), 954(h)-(i) (I 994 \& Supp. IV I998); see also I.R.S. Notice 98-35, I 998-27 I.R.B. 35, 35 (discussing the recent debate over and ultimate withdrawal of I.R.S. Notice 98-I I, I 998-I C.B. 433, which attempted to limit the use of check-the-box to avoid Subpart F). Grubert suggests that his data indicate that U.S. CFCs in Caribbean tax havens pay U.S. $\operatorname{tax}$ on less than $50 \%$ of their book income, which indicates that they are effectively avoiding the application of Subpart F (by using hybrids). See Grubert, supra note 67, at 20.

75 See, e.g., GARY Clyde HufBauer, U.S. TAXATION OF INTERNATIONAL INCOME: BLUEPRINT FOR REFORM 96-97 (I992).

76 It should be noted that Belgium does tax other corporations quite heavily, and even has a classical system (one that taxes corporations and shareholders separately), as does the United States.

77 See Roger H. Gordon \& Jeffrey K. MacKie-Mason, Tax Distortions to the Choice of Organizational Form, 55 J. PUB. ECON. 279, 280-8I (I994). 
enced by tax considerations. ${ }^{78}$ This can be demonstrated in several ways. First, one can consider Wilson's evidence, gleaned from interviews with corporate management, that "tax considerations largely dictate location decisions for .... administrative and distribution centers." ${ }^{9}$ Belgium and other jurisdictions that market themselves as "corporate headquarters tax havens" seek to attract just such centers engaged in supervising worldwide manufacturing operations. Like production tax havens, such headquarters tax havens are proliferating because of tax competition.

Second, one can consider industries that are taxed exclusively on a residence basis because taxation at source is considered too difficult or too likely to lead to multiple taxation. Prominent examples include the shipping and commercial insurance industries, which are not subject to source-based income taxation because they do not have permanent establishments and can locate their production in tax havens. In these cases, the corporate residence is frequently also in a tax haven (often Liberia or Panama for shipping, Bermuda for insurance) and therefore no income tax is levied. (Excise taxes are typically levied at source as a minimal but inadequate substitute.)

Third, there is evidence that even the current loose U.S. antideferral rules may have induced attempts to change corporate residence to avoid them. The United States has recently imposed a tax on publicly traded U.S. corporations that change the residence of their corporate parent to another jurisdiction. ${ }^{80}$ This rule was prompted by a wellpublicized case of a cosmetics distributor that reincorporated tax-free in the Cayman Islands to avoid application of Subpart $F$ to its future subsidiaries. ${ }^{81}$

Reincorporating in Panama or in the Cayman Islands may be a step most U.S. multinationals would be unwilling to take. But establishing the corporate headquarters and formal corporate residence in Belgium, even when the entrepreneurs are U.S. residents, would seem

78 Average effective tax rates significantly affect the choice of corporate domicile. See Julie $\mathbf{H}$. Collins \& Douglas A. Shackelford, Corporate Domicile and Average Effective Tax Rates: The Cases of Canada, Japan, the United Kingdom, and the United States, 2 INT'L TAX \& PUB. FIN. 55, 56 (I995).

79 Wilson, supra note 58 , at 229.

80 See I.R.S. Notice 94-46, I994-I C.B. 356, 356-57.

81 See Lee A. Sheppard, News Analysis: Last Corporate Taxpayer Out the Door, Please Turn Out the Lights, I 999 TAX NOTES TODAY 30-5, III 4-6, available in WL I999 TNT 30-5. Similarly, in I 982, McDermott Inc. changed its site of incorporation to Panama to avoid current U.S. tax on its foreign source income. See James R. Hines, Jr., The Flight Paths of Migratory Corporations, $6 \mathrm{~J}$. ACCT. AUdITING \& FIN. 447, 462-67 (I99I). McDermott's reorganization led to the enactment of the "anti-inversion" provision, see Deficit Reduction Act of 1984 , Pub. L. No. $98-369, \S$ I 33 (a), 98 Stat. 494, 667-68 (codified as amended at I.R.C. § I248(i) (1994 \& Supp. II I996)), which was expanded in 1996, see Small Business Job Protection Act of 1996, Pub. L. No. 104-188, $\$ 1702(\mathrm{~g})(\mathrm{I})(\mathrm{d})$, 1 10 Stat. I 755, I872-73. 
to carry little business risk. ${ }^{82}$ Moreover, the shares of most multinationals are currently traded on several exchanges, diminishing the significance of the country in which the parent is incorporated because the shareholder-protection laws of the trading jurisdiction will typically apply. Although a move may be unlikely for established U.S. corporations like General Motors or even Intel, ${ }^{83}$ the major players in new industries have yet to incorporate, and future incorporation decisions may well be influenced by tax considerations. ${ }^{84}$

The Treasury discussion paper on taxation of electronic commerce suggests that because of such considerations, "a review of current residency definitions and taxation rules may be appropriate." ${ }^{\text {"s }}$ But it is hard to see what definition of corporate residence can be adopted that will avoid these problems. A definition that focuses on the corporation's place of management may prove unworkable because the rise of corporate intranets has eliminated the need for corporate boards to meet in one physical location. A rule that focuses on the residence of shareholders is likewise problematic because (as stated above) the shares of most multinationals now trade on several exchanges, leading to many corporate residences and no clear way to divide the tax base among them. ${ }^{86}$ As long as residence jurisdictions compete with each other for the location of corporate headquarters, effective residencebased taxation seems unlikely.

To sum up: Corporate income from cross-border transactions is increasingly unlikely to be taxed in the demand jurisdiction because of the absence of a permanent establishment. Such income is also unlikely to be taxed in the supply jurisdiction because production can take place in production tax havens. Finally, taxation by the corporate residence jurisdiction is similarly unlikely because of deferral and headquarters tax havens. Thus, unless the current rules are changed,

\footnotetext{
82 The anti-deferral rules do not apply to a closely held foreign corporation earning active business income.

83 However, even established corporations may be acquired by foreign multinationals, as the Daimler acquisition of Chrysler shows. If the majority of the shareholders in the new parent corporation are foreign, such a transaction escapes I.R.C. $\$ 367$, so that any future growth of the combined multinational can occur abroad free of the confines of Subpart F. See Treas. Reg. $\$$ I.367(a)3 (c) (as amended in 1999).

84 Interstate reincorporation has been common within the United States, where both corporate and tax considerations have led many corporations to move to New Jersey and then to Delaware. See. Phillip I. Blumberg, The Multinational Challenge to Corporation LaW 56-58 (1993) (discussing New Jersey's role in this evolution); Henry N. Butler, Nineteenth-Century Jurisdictional Competition in the Granting of Corporate Privileges, I4 J. LFGAL STUD. 129, I52-63 (I985) (discussing the origins of jurisdictional competition for corporate sites).

85 OFFICE OF TAX POLICY, supra note 39 , at 22-23.

86 Section IV.C discusses the possibility of ending corporate taxation altogether and taxing all income at the shareholder level, and rejects it on inter-nation equity grounds.
} 
such income is increasingly likely to escape taxation altogether. Part III considers whether this situation is problematic.

\section{Revenue Losses}

The preceding discussion indicates that it is possible to avoid income taxation on cross-border portfolio and direct investment. But how much revenue is actually lost in this way? This question turns out to be much harder to answer given the present state of the publicly available data.

The recent OECD Report on harmful tax competition argues that tax competition should be curbed primarily to prevent erosion of the revenue bases of OECD member countries. ${ }^{87}$ At the very beginning of the chapter containing its recommendations, the OECD Report states, "Governments cannot stand back while their tax bases are eroded through the actions of countries which offer taxpayers ways to exploit tax havens and preferential regimes to reduce the tax that would otherwise be payable to them." 88 Unfortunately, the OECD Report contains no numerical data to bolster its claim that tax bases are eroding as a result of harmful tax competition. ${ }^{89}$ Aggregate data on tax collections, which section III.B reviews, do not support the claim: there is no evidence that overall revenue from the personal or corporate income tax in OECD member countries has declined as a percentage of either GDP or total tax revenue from 1965 to $1995 .{ }^{90}$ However, these data do not distinguish between revenue from labor and revenue from capital, and it may be that a decline in the tax revenues from taxing capital is masked by a rise in revenues from taxing labor. This hypothesis would be consistent with the findings on changes in the overall tax mix reported below in section III.B.

This section will present the publicly available data on the revenue effects of tax competition. Although these data are sparse and incomplete, some of them are quite suggestive.

I. Personal Income Tax. - Assessing the revenue losses from tax competition in the personal income tax context is difficult because it

87 See OECD REPORT, supra note 26 , at 8 , 14. This Report is discussed in detail in section V.B.

88 Id. at 37.

89 See id. at 17 ("The available data do not permit a detailed comparative analysis of the economic and revenue effects involving low-tax jurisdictions."). The Report does note, however, that "the available data do suggest that the current use of tax havens is large, and that participation in such schemes is expanding at an exponential rate." Id.

90 See infra section III.B. Data for 1995 through 1999 do suggest a declining trend in corporate income tax rates in OECD and EU countries (from an average of $37.6 \%$ to $34.9 \%$ in the OECD and from $39 \%$ to $36 \%$ in the EU). It is less clear whether this factor translates to lower effective tax rates or lower revenues. See James R. Hines, Jr., Lessons From Behavioral Responses to International Taxation, 52 NAT'L TAX J. 305 (I999). 
involves (illegal) tax evasion rather than (legal) tax avoidance. ${ }^{91} \mathrm{Al}$ though a number of competing methods of approximating such losses exist, ${ }^{92}$ each with its own problems, they all reach consistently high estimates. ${ }^{93}$ The available estimates of the untaxed portion of developed countries' economies range from $6 \%$ to $20 \%$ of GDP in the United States (in 1980 ) to $20 \%$ to $33 \%$ of GDP for Italy (in I 982 ). ${ }^{94}$

These numbers, however, include much domestic tax evasion unrelated to tax competition. Chander Kant summarizes the available data on capital flight using a variety of more relevant measures. ${ }^{95}$ Given the wide availability of opportunities described in section II.A, it is reasonable to assume that most departing capital is invested in countries where it is not subject to taxation at its source. Although Latin America accounts for the largest share of capital flight, virtually all regions of the developing world experience this phenomenon. ${ }^{96}$ Estimates of capital flight from all developing countries for the period from 1980 to 1988 range from $\$ 15$ billion to $\$ 60$ billion per year. ${ }^{97}$ The

91 In theory, it should be possible to obtain a good sense of the magnitude of revenue losses by summing up the withholding taxes that are forgone by OECD member countries through measures like the portfolio interest exemption. However, the most recent compilation of tax expenditure data by the OECD does not contain these data because most countries (including the United States) do not regard the reduction of withholding taxes as a departure from their normal tax base. See OECD, TAX EXPENDITURES: RECENT EXPERIENCES (I996) [hereinafter TAX EXPENDITURES]. The only exception is Canada, which estimates tax losses for each year from 1993 to 2000 of Cdn $\$ 325$ million to $\$ 430$ million from not withholding tax on interest on deposits and $\mathrm{Cdn} \$ 460$ million to $\$ 550$ million from not withholding on interest on long-term corporate debt. See Department of Fin., Government of Can., TAX EXPENDITURES I998, reprinted in 98 WORLDWIDE TAX DAILY 138-16, tbl.2 (1998), available in WL 98 WTD I38-16. Thus, Canada estimates that it loses about Cdn $\$ 1$ billion (U.S. $\$ 650$ million) per year by forgoing withholding although if it tried to collect this revenue unilaterally, the investments would presumably move elsewhere.

92 The most commonly used is the national accounts method, which involves comparing the base of a particular tax as estimated by the national accounts authorities and the base as reported to the tax authorities after making appropriate adjustments. See VITO TANZI \& PARTHO SHOME, Tax Evasion: Causes, Estimation Methods, and Penalties: A Focus on latin America 13 (I993). Other techniques of direct approximation include the budget survey method, a direct taxpayer survey, and the sampling method. Indirect methods, which focus on the underground economy, include: the expenditure method, which assumes that evaded income will show up as consumption; the physical input method, which assumes that certain inputs, such as electricity, should relate to taxable outputs; and the monetary approach, which associates evasion with currency holding. See id. at $13-19$.

93 See id. at $19-22$ \& tbl.3.

94 See id. at 20 tbl.3. For Portugal, a 1975 study estimated that $30 \%$ of earned income and $40 \%$ of unearned income goes untaxed. See id. The estimates for developing countries are as follows: Argentina (I989), 50\% of GDP; Bolivia (I986), $44 \%$ of GNP; Brazil (I989), $50 \%$ of GDP; Chile (I 986 ), $14 \%$ to $32 \%$ of GNP; Dominican Republic (I 986 ), $14 \%$ to $32 \%$ of GNP; Ecuador (I 986 ), $30 \%$ to $32 \%$ of GNP; Guatemala (I986), $30 \%$ to $32 \%$ of GNP; Honduras (I 986 ), $30 \%$ to $32 \%$ of GNP; Mexico (1986), 30\% to $32 \%$ of GNP; and Peru (1986), $35 \%$ of GNP. See id.

95 See KANT, supra note 29, at 5-10.

96 See id. at 5.

97 See id. at 21 tbl.5. 
total capital accumulated abroad from Latin America alone was estimated in 1992 at $\$ 300$ billion. ${ }^{98}$ For developed countries, estimates are rare, but Dooley estimates capital flight from the United States between 1980 and 1982 at $\$ 250$ billion. ${ }^{99}$

It seems reasonable to assume that the income from such capital is untaxed by either the source country or the residence country. ${ }^{100}$ If so, positing a $10 \%$ average rate of return and a $50 \%$ individual tax rate would put the Latin American countries' revenue loss on $\$ 300$ billion of departed capital at about $\$$ I $_{5}$ billion per year. Though significant, this figure is probably far too low because it assumes that the initial capital investment represents after-tax income. If, more realistically, one assumes that the migrating capital was never taxed, the lost revenue from $\$ 300$ billion held abroad would be an initial $\$ 150$ billion plus an additional $\$ 15$ billion per year, assuming the same $50 \%$ tax rate. ${ }^{101}$ The total lost revenue for all developing countries may be as high as twice that amount.

These very high numbers suggest that developing countries could raise significant tax revenues were they able to tax the income that their residents invest abroad. ${ }^{102}$ Such revenue gains could be very important: the United Nations estimates that basic social services (such as universal primary education) could be assured for all developing countries for a mere $\$ 30$ to $\$ 40$ billion a year. ${ }^{103}$ The revenue gains for developed countries (such as Germany) could also be quite large in absolute terms, although much smaller as a percentage of total tax revenues. Thus, tax competition seems to lead to significant tax base erosion of the personal income tax, which is still a major - if not the largest - tax base for most developed and developing countries.

2. Corporate Income Tax. - Estimating revenue losses from tax competition in the corporate income tax context should be easier than in the personal income tax area because, as explained in section II.B, the revenue loss involves legal tax avoidance rather than illegal tax evasion. Most developed countries defer taxing or exempt the active

\footnotetext{
98 See id. at I (citing Pedro-Pablo Kuczynski, International Capital Flows into Latin America: What Is the Promise?, in PROCEEDINGs of THE WORLD BANK ANNUAL CONFERENCE ON DEVELOPMENT ECONOMICS 323 (Lawrence H. Summers \& Anwar M. Shah eds., I992))

99 See Dooley, supra note 32 , at 79.

100 See supra sections II.A-B.

101 This example assumes that it would be possible to tax the underlying capital, which may be harder to tax than the income because it can be left in tax havens.

102 This suggestion assumes that the residence country, not the source country, would receive the tax revenue. The solution that Part $\mathrm{V}$ proposes is intended to make residence-based taxation possible.

103 See United Nations human Dev. Programme, Human Development Report 1997, at 12 box 6.4 (1997) [hereinafter HUMAN DEVELOPMENT REPORT].
} 
business income of foreign subsidiaries of "their" MNEs, while developing countries grant explicit tax holidays to those subsidiaries.

Nevertheless, there is little publicly available data on revenue losses resulting from deferral, from exemption by home countries, or from preferential tax regimes in host countries. OECD member countries are the home countries for about eighty-five percent of the world's MNEs. ${ }^{104}$ However, the OECD's most recent data on tax expenditures reveal that no member countries, except for the United States and France, quantify the revenue lost by granting exemption or deferral to the foreign source active business income of their MNEs. ${ }^{105}$ The United States estimates its 1997 revenue loss from "deferral of income from controlled foreign corporations" at $\$ 2.2$ billion, a figure it expects to swell to $\$ 3.4$ billion by $2003 .{ }^{106}$ France estimates the potential revenue gain from taxing its MNEs on their foreign source profit in I 994 at 18 billion French francs (about $\$ 3.3$ billion as of December I 994$) .107$

These numbers are significant, but they represent only a small portion of all MNEs. However, their true significance for each home country can be assessed only by comparing these figures to other tax expenditures and to the overall budget. For the United States, $\$ 3$ billion is a small tax expenditure compared to the largest, which amount to $\$ 50$ billion or more. ${ }^{108}$ It is also a small figure in terms of corporate income tax receipts - $\$ 189$ billion in $1998 .{ }^{109}$ For France, on the other hand, FF 18 billion in 1994 represented the second largest tax expenditure in the budget. ${ }^{110}$ It also represented a larger share of to-

\footnotetext{
104 See UNITED NATIONS CONFERENCE ON TRADE AND DEV., WORLD INVESTMENT REPORT I 999: FoREIGN DIRECT INVESTMENT AND THE CHALLENGE OF DEVELOPMENT 5-6 tbl.I.I (I 999) [hereinafter WORLD INVESTMENT REPORT].

105 See TAX EXPENDITURES, supra note 91, at 62 tbl.9, 112 tbl. 9.

106 Budget Analytical Perspectives, Chapter 5-Tax Expenditures, 98 WORLDWIDE TAX DAILY 25-2 I, tbl. 5-1 (1998), available in WL 98 TNT 25-2 1 .

107 See TAX EXPENDITURES, supra note 91, at 62 tbl.g.

108 See Budget Analytical Perspectives, Chapter 5 - Tax Expenditures, supra note 106, at tbl.5I. The largest U.S. tax expenditures for FY 1999 were the exclusion of pensions $(\$ 72.375$ billion), insurance proceeds ( $\$ 14.200$ billion), and the home mortgage interest deduction ( $\$ 53.695$ billion). See id.

109 See Revenue Provisions in President's Fiscal Year 2000 Budget: Hearing Before the House Comm on Ways and Means, ro6th Cong. 103-04 (1999) (statement of Kenneth J. Kies, Managing Partner, Washington National Tax Services, PriceWaterhouseCoopers LLP).

110 France's largest tax expenditure for 1994 was the "quotient familial" system of allowances for family size, which totaled FF 68 billion ( $\$ 12.7$ billion U.S.). Other significant tax expenditures were the exemption of income from investment growth bonds (FF 18 billion), the reduced rate for long-term capital gains (FF I4.5 billion), and the exemption of imputed income from in-kind housing (FF I 3.7 billion). No other expenditure exceeded FF Io billion. See TAX EXPENDITURES, supra note 91 , at $6 I-63$ tbl.9.
} 
tal receipts from the corporate tax (FF II9 billion in 1994). ${ }^{111}$ These figures may explain why France was one of the OECD member countries most interested in pushing the tax competition issue. ${ }^{112}$

Information is also sparse for host countries that grant tax holidays or other preferential treatment to foreigners. The OECD report on tax competition gives no figures, except that total direct investment by $\mathrm{G}_{7}$ countries in traditional tax havens in the Caribbean and South Pacific increased more than fivefold from 1985 to 1994 , to more than $\$ 200$ billion. ${ }^{113}$ This represented "a rate of increase well in excess of the growth of total outbound Foreign Direct Investment."114 If one assumes that the major motivation of such investment in traditional tax havens is tax avoidance, ${ }^{115}$ and therefore that most of the income from the $\$ 200$ billion escapes the net of existing antideferral regimes, this number would represent a significant loss of corporate tax revenue for the $\mathrm{G}_{7}$ countries. ${ }^{116}$

Two OECD member countries, Ireland and Belgium, have preferential tax regimes targeted at foreigners. Ireland provides a reduced tax rate of $10 \%$ to foreign MNEs that established manufacturing facilities in selected areas (making it a "production tax haven"). 117 Belgium grants near-complete tax relief to "centres de coordination" (making it a "headquarters tax haven"). ${ }^{118}$ Ireland's estimated revenue loss from its reduced tax rate in I $99 \mathrm{I}$ and $\mathrm{I} 992$ was 748.9 million Irish pounds (about $\$ 1.2$ billion). ${ }^{19}$ Belgium's estimated revenue loss from its headquarters tax reduction in 1992 was 46 billion Belgian francs

111 See OECD, REvenUe STATISTICS OF OECD MEMBER CoUNTRIES, I965-I995, at I I tbl.45 (1996).

112 France co-chaired the OECD's Special Sessions on Tax Competition, which drafted a report focusing entirely on corporate taxes. See OECD REPORT, supra note 26, at 7 . The other co-chair was Japan. See id.; infra p. 1603.

113 See OECD REPORT, supra note 26 , at 17.

114 Id.

115 This seems a reasonable assumption, given those countries' lack of other resources that would attract investors there. See Hines \& Rice, supra note 46 , at $150-53$.

116 If the $\$ 200$ billion generates income at $10 \%$ a year and the average corporate tax rate in $\mathrm{G}_{7}$ countries is $35 \%$ (both reasonable assumptions), the $\$ 200$ billion invested in traditional tax havens represents a yearly revenue loss of $\$ 7$ billion. Interestingly, Grubert reports, based on U.S. Treasury data, that even Subpart F, which is generally regarded as the toughest anti-deferral regime in the world, captures only $50 \%$ of the income of CFCs in Caribbean tax havens. See Grubert, supra note 67 , at 20 .

117 See TAX EXPENDITURES, supra note 91 , at 73 tbl.12. Ireland has agreed to eliminate its tax haven for new projects by 2003 and for existing projects by $20 \mathrm{rr}$; in its place, it is phasing in a low, generally applicable tax rate, which will be fully in place by 2003 . See Mary Walsh, Ireland 1998 Tax Review, 98 WORLDWIDE TAX DAILY 25 I-I I, III 3-4 (I998), available in WL 98 TNI 25 III.

118 See TAX EXPENDITURES, supra note $9 \mathrm{I}$, at 33 tbl.4.

119 See id. at 74 tbl. 2. 
(about $\$$ I.5 billion). ${ }^{120}$ These numbers are relatively small, but far from negligible in the budgets of Ireland and Belgium. Ireland's tax expenditure on the production tax haven was the largest such expenditure in its budget for the tax year I99I-92.121 Belgium's tax expenditure for the headquarters tax haven was the fifth largest expenditure in its 1992 budget. ${ }^{122}$

Tax expenditure figures are of doubtful accuracy, however. In particular, the U.S. figures (which are determined by methods that are relatively sophisticated compared to those used to calculate other countries' expenditures) may be understated because they do not take into account any behavioral changes that shift income overseas, including those caused by such legal changes as amendments to the corporate tax laws. Thus, the $\$ 2$ billion to $\$ 3$ billion estimated annual revenue loss from deferral is not an accurate estimate of the revenue that would be lost were Subpart F (the principal U.S. antideferral regime $)^{123}$ repealed or severely curtailed, as some have suggested. ${ }^{124}$ In that case, U.S.-based MNEs would presumably shift revenues abroad, resulting in increased tax revenue losses. Nor is the $\$ 2$ billion to $\$ 3$ billion figure necessarily even a good estimate of the revenue that could be gained if Subpart $\mathbf{F}$ were expanded to cover all income because, as section II.B suggests, such an expansion could encourage more MNEs to incorporate outside the United States and further deprive it of tax income. ${ }^{125}$ In addition, the U.S. lost-revenue estimate has not changed (except for adjustments for inflation and other macro-

120 See id. at 34 tbl.4. It is not clear, however, whether this revenue could have been collected absent that tax expenditure. Part IV offers a cost-benefit analysis of this issue.

121 The expenditure for the married person's allowance, at Ir $£ 745.8$ million, was almost as large, and no other expenditure exceeded Ir $£ 500$ million. See id. at 73 tbl. 12.

122 The largest expenditure, at BF 112 billion, was the exemption of dividends. See id. at 33 tbl.4.

123 See I.R.C. $\$ \$ 95$ I-96 I (1994 \& Supp. IV I 998).

124 See, e.g., HUFBAUER, supra note 75, at $\mathrm{I} 36$; NFTC PROJECT, supra note $33, \mathrm{I} \mathrm{I}$. The oneyear exception from Subpart $\mathrm{F}$ for "active financing income" of banks and insurance companies was estimated to cost $\$ 1.4$ billion, or about $50 \%$ of the entire loss from deferral. See Letter from Donald C. Lubick, Assistant Secretary for Tax Policy, Department of the Treasury, to Senator Byron Dorgan, II 8 (Feb. 8, I999), reprinted in Treasury Shares Dorgan's Concerns About CFC Extenders Provision, 1999 TAX NOTES TODAY 32-25, available in WL 1999 TNT 32-25. The foreign sales corporation regime (recently challenged by the WTO) costs $\$ 2$ billion. See Robert Goulder, WTO Panel Issues Final Report Condemning U.S. FSC Regime, I999 TAX NOTES TODAY I83-3, III $\mathrm{I}, 6$, available in WL 1999 TNT $183-3$.

125 Another issue that affects the accuracy of the estimate is that the revenue estimate assumes a continuation of the Subpart F method of taxing MNEs, which uses a deemed dividend to the parent rather than a consolidated approach. As a result, CFCs with losses do not reduce the revenue estimate. In addition, repealing deferral implies treating all the interest expense of the MNE as fungible, as opposed to the current rule that only U.S. interest is allocated based on worldwide assets while foreign interest reduces foreign source income (and thus reduces the availability of foreign tax credits). If loss offsets and interest fungibility are both allowed, the $\$ 2$ billion revenue estimate shrinks considerably. See Frisch, supra note 72 , at 586. 
economic variables) since the 1980 , even though Treasury data indicate a significant reduction in the average effective foreign tax rate. ${ }^{126}$ Available data, however, suggest that the total revenue to be gained from repealing deferral is relatively small (although significant in relation to total U.S. corporate tax revenues from foreign source income). ${ }^{127}$

On the other hand, the United States has the strictest antideferral regime of all OECD member countries, and its corporate tax rate is relatively low. A country like Japan, which has an ineffective antideferral regime and a high effective corporate tax rate, ${ }^{128}$ is likely to face a much more significant loss from revenue deferral. This greater loss may explain why Japan was at the forefront of the OECD effort to combat harmful tax competition and co-chaired the OECD's Special Sessions of the Committee on Fiscal Affairs, which drafted a report on this subject. ${ }^{129}$

Thus, the limited available data on revenue losses from competition in the corporate income tax area suggest that these losses, although significant, are probably much smaller than the potential losses in the personal income tax area. On the other hand, revenue losses may vary dramatically from country to country depending on their effective corporate tax rates and the stringency of their antideferral rules. Some countries, such as France and Japan, may suffer significant revenue losses from corporate tax competition, even in terms of their overall budgets. In other countries, such as the United States, those losses may be relatively insignificant.

\section{The Problem of TAX Competition From A GLOBAL NORMATIVE PERSPECTIVE}

In Part II, I argued that the combination of increased capital mobility and tax competition leads to the likelihood that cross-border

\footnotetext{
126 See infra pp. 1622-24.

127 Altshuler and Newlon calculate from I986 Treasury data that the United States collected only $\$ 1.585$ billion from $\$ 47$ billion in foreign source income earned by 340 U.S.-based multinationals (a 3.4\% effective tax rate). See Altshuler \& Newlon, supra note 44, at 90, 91 tbl. 3.2. Thus, an additional $\$ 2$ billion (to use the lower estimate) would more than double tax collections from this source. The total foreign source income now is significantly higher because of the increase in outbound foreign direct investment since $I 986$.

128 See Lucy Chennells \& Rachel Griffith, TAXing Profits IN A Changing World 150 tbl.I.4 (1997) (estimating the Japanese effective tax rate in 1994 (the most recent year) at between $40.3 \%$ (ATR) and $52.9 \%$ (EMTR)); Julie H. Collins \& Douglas A. Shackelford, Corporate Domicile and Average Effective Tax Rates: The Cases of Canada, Japan, the United Kingdom, and the United States, 2 INT'L TAX \& PUB. FIN. 55, 61 tbl.2 (1995) (estimating the Japanese average effective tax rate from $I 982$ to $I 99 I$ at between $52 \%$ and $57 \%$ ). In both cases these are the highest rates among the countries surveyed (Australia, Canada, France, Germany, Ireland, Italy, Japan, Spain, the United Kingdom, and the United States).
}

129 See OECD REPORT, supra note 26, at 7; supra note I 12. 
flows of capital will be taxed more lightly than either domestically invested capital or domestic labor. In this Part, I attempt to evaluate whether this situation is problematic from a global efficiency or equity perspective. I then proceed to balance those considerations against democratic countries' right to determine the size of their governments, and to develop a distinction between harmful and acceptable forms of tax competition.

\section{A. Global Efficiency and Global Welfare}

\section{Capital Export Neutrality and Capital Import Neutrality. -} The traditional argument in favor of imposing the same tax rate on all income from capital, whether invested at home or abroad, has been made in the name of capital export neutrality (CEN), a concept first developed by Peggy Musgrave. ${ }^{130}$ CEN refers to an investor's choice between investing her savings in her country of residence or in a foreign host country. CEN exists when home- and host-country investments that earn the same pretax return also yield the same after-tax return. ${ }^{131}$ CEN is violated, for example, if neither the home nor the host country taxes the income from an investment in the host country, while both tax an investment in the home country. In that case, the investor would prefer to invest in the host country rather than in the home country, even if the pretax yield on the domestic investment were higher. ${ }^{132}$ The result is a deadweight loss from a global efficiency perspective because investments will not be allocated to their most productive (highest-yielding) pretax uses. In the long run, as more capital flows to host-country investments, the pretax returns on those investments will fall and pretax returns on home-country investments will rise until equilibrium is restored (when after-tax returns are equalized). The deadweight loss, however, will remain the same because some less productive host-country investments will be made at the expense of more productive home-country investments (that is,

\footnotetext{
130 See Peggy B. MUSgrave, United States Taxation of Foreign INVESTMENT INCOME: IsSUES AND ARguments (I969); see also James R. Hines, Jr., The Case Against Deferral: A Deferential Reconsideration, 52 NAT'L TAX J. 385 (I 999) (re-evaluating the validity of CEN analysis).

131 See RichaRd E. CAVES, MULTINATIONAL ENTERPRISE AND ECONOMIC ANALYSIS 227 (1982).

132 Assume, for example, that an investor faces a choice between a home-country investment yielding 100 and a host-country investment yielding 70 . In a tax-free world, the investor would choose the home-country investment. Now assume that the home-country investment is taxed at $40 \%$ while the host-country investment is untaxed (if, for example, the host country does not tax the investment income of nonresidents and the home country is unable to enforce its tax jurisdiction on foreign source income). In that case the investor faces a choice between a home-country investment yielding 60 ( 100 minus 40 in tax) and a host-country investment yielding 70 ( 70 minus 0 in tax). The investor would then choose the host-country investment even though it yields the lower pretax return.
} 
capital will be oversupplied in the host country and undersupplied in the home country). ${ }^{133}$

This traditional argument has led most economists to support residence-based taxation of worldwide income as the optimal tax rule for international taxation because, in the absence of host-country taxes, residence-based taxation maintains CEN. According to Razin and Sadka, adopting the residence principle leads to an efficient allocation of the world's pool of investment capital:

If a country adopts the residence principle, taxing at the same rate capital income from all sources, then the gross return accruing to an individual in that country must be the same, regardless of which country is the source of that return. Thus, the marginal product of capital in that country will be equal to the world return to capital. If all countries adopt the residence principle, then capital income taxation does not disturb the equality of the marginal product of capital across countries which is generated by a free movement of capital. ...

... [If] residents of a country are not taxed on their income from foreign sources .... . [and] the tax rate is not the same in all countries, then the marginal product of capital is also not the same in all countries. In this case the international allocation of the world stock of capital is not efficient. ${ }^{134}$

The economic case against $\mathrm{CEN}$ is traditionally made in the name of capital import neutrality (CIN). CIN requires that the earnings from capital in a host country be taxed at the same rate for both domestic and foreign investors. ${ }^{135} \mathrm{CIN}$ is violated, for example, if foreign investors in a host country are taxed on their foreign investment income at their home-country rate (as required by $\mathrm{CEN}$ ) while the host country does not levy an income tax on its citizens' investment income. In that case, domestic (host-country) investors have a different net return on their investment in the host country than do foreign (homecountry) investors. The results are that intertemporal marginal rates

133 See Assaf Razin \& Efraim Sadka, International Tax Competition and Gains from Tax Harmonization, 37 ECON. LETTERS 69, 69-70 (I99I) (hereinafter Razin \& Sadka, International Tax Competition].

${ }_{134}$ Id. If governments cannot effectively tax foreign source income, Razin and Sadka advocate capital controls, or if those are not feasible, subsidies to domestic investment. See Assaf Razin \& Efraim Sadka, Optimal Incentives to Domestic Investment in the Presence of Capital Flight 9 (I989) (unpublished IMF Working Paper); see also ASSAF RAZIN \& EFRAM SADKA, CAPITAL MARKET INTEGRATION: ISSUES OF INTERNATIONAL TAXATION 5-6 (David Horowitz Inst. for the Research of Developing Countries Paper No. $4 / 90$, 1989) (" $[$ O]ptimal policy requires an efficient allocation of capital between investment at home and abroad so that the marginal product of domestic capital must be equated to the world rate of interest ...."). Razin and Sadka derive this result from an application of Peter Diamond and James Mirrlees's concept of "production efficiency." Peter A. Diamond \& James A. Mirrlees, Optimal Taxation and Public Production I: Production Efficiency, 6I AMER. ECON. REV. 8 (1971).

135 See CAVES, supra note I3I, at 227. 
of substitution (that is, the choice between present and future consumption) will differ between countries, and the international allocation of world savings will be distorted. ${ }^{136}$

In a classic article, Thomas Horst showed that if tax rates vary among countries, it is impossible to achieve CEN and CIN simultaneously. ${ }^{137}$ How, then, is one to choose between policies that assure the efficient allocation of world investments on the one hand (CEN) and world savings on the other (CIN)? Horst showed that the choice depends on the relative elasticities (that is, responsiveness to taxation) of the supply and demand of capital. If the supply of capital is fixed, so that savings rates are not responsive to taxation, and the demand for capital is elastic, CEN is preferred because it ensures an efficient allocation of the home country's supply of capital. If the demand for capital is fixed while the supply is elastic, CIN is preferred because it ensures an efficient satisfaction of the host country's demand for capital. ${ }^{138}$

Horst argued that the most plausible assumption in the absence of empirical evidence is that the elasticities of supply and demand for capital are the same and are somewhere between zero (fixed) and one (perfect elasticity). Thus, a policy that falls between CEN and CIN is warranted. ${ }^{139}$ Why, then, do most economists prefer CEN to CIN? ${ }^{140}$ Empirical evidence suggests that the elasticity of demand for capital is considerably greater than the elasticity of supply - that the choice between saving and consuming is less responsive to taxes than is the

\footnotetext{
136 See Razin \& Sadka, International Tax Competition, supra note I33, at 70. In terms of the previous example, see supra note $\mathrm{I}^{2}$, the home-country investor prefers the domestic investment (yielding Ioo before tax) over the host-country investment (yielding 70 before tax) when both are subject to a tax of $40 \%$ (yielding an after-tax return on the domestic investment of 60 and an after$\operatorname{tax}$ return on the foreign investment of 42 ). In the case of CEN, however, he will have a lower after-tax yield (60) than will a host-country investor in the host country who faces a $0 \%$ tax rate (70). All factors being equal as between home- and host-country residents, after-tax savings will thus be lower in the home country.

137 See Thomas Horst, A Note on the Optimal Taxation of International Investment Income, 84 Q.J. ECON. 793 (1980).

138 See id. at 796 .

139 See id. at 797. Horst acknowledges that the U.S. policy meets his criteria but argues that the United States's compromise between CEN and CIN would be only coincidentally correct according to the criteria he suggests. See id. at 797 n.5.

140 In addition to Razin and Sadka, several authors evince a preference for CEN over CIN on the assumption that foreign source income can be effectively taxed. See, e.g., Michael P. Devereux \& Mark Pearson, European Tax Harmonisation and Production Efficiency, 39 EUR. ECON. REV. I657, I660 (I995) (stating that "an optimal tax structure would preserve production efficiency but not exchange efficiency [the efficient allocation of savings]" and that "CEN is a necessary condition for production efficiency"); James Levinsohn \& Joel Slemrod, Taxes, Tariffs, and the Global Corporation, 5 I J. PUB. ECON. 97, 104-05 (I993) (arguing that "[t]he optimality of levying taxes that do not discriminate by location is ... preserved when strategic considerations are introduced," but supporting the reduction of taxes on foreign source income if tax policy cannot discriminate between strategic and nonstrategic sectors (emphasis omitted)).
} 
choice among alternative investment vehicles. For example, in a recent article on the efficiency of the investment tax credit, Austan Goolsbee finds that the demand elasticity of investment exceeds I.0.141 Other empirical studies examining aggregate data on savings flows suggest that the elasticity of savings with respect to the rate of return is small, while the elasticity of aggregate investment is probably higher. ${ }^{142}$ According to a I994 OECD study, "there is no clear evidence that taxation affects the overall level of savings by households." 143 The basic reason seems to be that many individuals have fixed targets for the amount of savings they hope to have at retirement. If this is so, a cut in the tax rate on savings would lead them to reduce, rather than increase, their saving rate because a lower before-tax saving rate would then enable them to reach their targets in the same amount of time. ${ }^{144}$

In addition to those arguments based on CIN, other arguments for rejecting CEN as the optimal policy stem from "national neutrality." The issue underlying this debate is the proper treatment of hostcountry taxes. CEN implies that they should be credited by the home country and, moreover, that the credit should be unlimited (that is, that taxes at rates exceeding the home-country rate should be refundable), so as to leave the investor with equal after-tax rates of return on home- and host-country investments. ${ }^{145}$ However, some economists have argued that host-country taxes should be deducted as costs rather than refunded as credits, so as to maximize the home country's national income, which includes both tax revenues and home firms' after-

141 See Austan Goolsbee, Investment Tax Incentives, Prices, and the Supply of Capital Goods, I 13 Q.J. ECON. I 2 I, I 45 (1998); see also Frisch, supra note 72, at 584 n. 10 (pointing out that to assume zero elasticity for the demand for capital is unrealistic because it requires not only that capital be used inelastically in the production of goods, but also that all consumers' demands for goods with differing capital intensities be inelastic). There are also indications that demand elasticity for capital may be increasing over time. See Altshuler, Grubert \& Newlon, supra note 63, at 2 (reporting an increase in the elasticity of investment to tax-rate differentials from I.8 in I984 to 2.8 in 1992).

142 See Devereux, supra note 33, at ror.

143 OECD, TAXaTION AND HOUSEHOLD SAviNG 3 (1994). The voluminous literature examining the effect on saving rates of cutting the capital gains tax reaches the same conclusion. See, e.g., Calvin H. Johnson, The Consumption of Capital Gains, 55 TAX NOTES 957, 970 (1992); George R. Zodrow, Economic Analyses of Capital Gains Taxation: Realizations, Revenues, Efficiency and Equity, 48 TAX L. REV. 4I9, 480 (1993); Bruce Anderson, Note, Strategic Choice Taxation: A Solution to the Federal Revenue Crisis, 1995 COLUM. BUS. L. REV. 28I, 314.

144 See Michael J. Graetz \& Deborah H. SChenk, Federal INCOME TAXation 574 (3d ed. I995).

145 In fact, however, no country grants an unlimited foreign tax credit (the U.S. credit has been limited since $\mathrm{I} 92 \mathrm{I}$ ) because it invites host countries to raise tax rates at the expense of the homecountry treasury. 
tax profits. ${ }^{146}$ Skeptics have pointed out that such "national neutrality" policies are likely to lead to retaliation, which ultimately would hurt the home country as well as violate CEN.147

Other economists have argued that a credit would lead the host country to raise its tax rate to capture increased tax revenue, and that the home country would then respond by raising its own rate to gain some of the benefits from restricting capital flows, resulting in too little trade. ${ }^{148}$ However, this line of analysis ignores evidence that the unilateral adoption of the foreign tax credit by the United States in $1918^{149}$ has led to a cooperative outcome that prevents double taxation and maximizes world welfare. ${ }^{150}$ In a cooperative game, the credit method turns out to be superior to the exemption or deduction method (which would be required by the CIN and national neutrality arguments, respectively) because it attains the efficient allocation of capital without requiring rate harmonization or side payments. ${ }^{151}$

In an influential article, Daniel Frisch contends that the CEN/CIN debate is obsolete because it ignores changes in the world economy that have taken place since the I 960 s. His main argument is that portfolio investments are more important determinants of efficient capital allocation than is FDI and, therefore, that CEN should be implemented for the former purpose but not for the latter. ${ }^{152}$ However, the fact that portfolio investment now exceeds FDI does not mean that the latter is unimportant in allocating investment, and applying CEN to portfolio investment should not preclude applying it to FDI as well. The location studies summarized above indicate that taxation has a major influence on multinationals' decisions to locate their investment capital. ${ }^{153}$

\footnotetext{
146 See, e.g., Martin Feldstein \& David Hartman, The Optimal Taxation of Foreign Source Investment Income, 93 Q.J. ECON. 613, 617 (I979).

147 Frisch, supra note 72, at 583-84; see also NFTC PROJECT, supra note 33, III 307-3 II.

148 See Eric W. Bond \& Larry Samuelson, Strategic Behaviour and the Rules for International Taxation of Capital, 99 ECON. J. 1099, I 104-07 (1989).

149 See I.R.C. \$ 901 ( I 994 \& Supp. IV I998).

150 See Gordon, supra note 35, at I 160-6 I (arguing that source-based taxation of capital is suboptimal when capital is mobile). Immobile factors must bear the burden of the tax because taxing them directly is more efficient and does not deter inbound investment. However, the survival of such source-based taxation can be explained by the United States enacting the credit as a "Stackelberg leader," that is, taking into account the reaction of other countries.

151 See Eckhard Janeba, Corporate Income Tax Competition, Double Taxation Treaties, and Foreign Direct Investment, 56 J. PUB. ECON. 31 I, 322 (1995).

152 See Frisch, supra note 72, at 587-9I.

153 See supra pp. 1590-92. If CEN is applied to portfolio investment and corporate and shareholder taxes are not integrated, then CEN for portfolio shareholders requires equalizing the corporate tax rate for the corporations they invest in, which in turn requires that both CEN and CIN apply at the corporate level. See Devereux \& Pearson, supra note 140, at I660. However, if portfolio shareholders receive a credit for corporate taxes paid (similar to the "indirect" credit given to
} 
Other economists have suggested that the Musgrave model for CEN overlooks or oversimplifies other important considerations. First, some scholars have suggested that foreign business operations may complement domestic activities that are particularly valuable due to intrinsic positive externalities, such as research and development (R\&D) or domestic job creation. ${ }^{154}$ However, even assuming that were the case (although the evidence is not compelling), it would be better to subsidize such activities directly because not all MNEs engage in them to the same extent. ${ }^{155}$

Second, Michael Devereux and Glenn Hubbard have argued that oligopolies may generate more profits by expanding their output and that this characteristic justifies treating such firms (Boeing, for example) more favorably from a tax perspective. ${ }^{156}$ But this argument assumes that important international oligopolies exist, that governments can commit in advance to their tax policies so as to encourage the expansion of output, and that treating foreign income more favorably for tax purposes encourages total output. None of these assumptions is free from doubt. ${ }^{157}$

Third, the Musgrave model for CEN assumes a first-best world in which there are no other economic distortions (such as other taxes), and in which the value of an additional unit of capital therefore equals its marginal product. Yet other taxes do in fact exist, such as the personal income tax on dividends, which may justify lighter taxation of corporate income earned abroad. ${ }^{158}$ However, there is no particular reason to limit the relief to foreign source income, and if broader relief is justified, the appropriate solution is some form of integration, rather than relief at the corporate level. ${ }^{159}$

corporate shareholders under U.S. law), maintaining shareholder-level CEN requires only CEN at the corporate level.

154 See Hines, supra note 130 , at 395

155 Indeed, R\&D is subsidized through the tax system. See James R. Hines, Jr., On the Sensitivity of RED to Delicate Tax Changes: The Behavior of U.S. Multinationals in the ro8os, in STUDiEs IN INTERNATIONAL TAXATION I49, I49-5 I (Alberto Giovannini, R. Glenn Hubbard \& Joel Slemrod eds., I 993).

156 See Michael P. Devereux \& R. Glenn Hubbard, Taxing Multinationals 5 (I 999) (unpublished Columbia University working paper, on file with the Harvard Law School Library).

157 See Hines, supra note 130 , at 395-96.

158 See id. at 397; Robert A. Green, The Future of Source-Based Taxation of the Income of Multinational Enterprises, 79 CORNELL L. REV. 18, 34 (1993).

159 It is possible to achieve integration at either the corporate or the shareholder level, but in practice, it is almost always done at the shareholder level (through dividend exemption or an imputation credit) to avoid automatic extension of integration to foreign shareholders. See ALVIN C. WARREN, JR., ALI FED. INCOME TAX PROJECT, INTEGRATION OF THE INDIVIDUAL AND CORPORATE INCOME TAXES: REPORTER'S STUDY OF CORPORATE TAX INTEGRATION 50-52 (1993); Michael J. Graetz \& Alvin C. Warren, Jr., Introduction to Integrating Corporate and Individual Income Taxes, 1999 TAX NOTES TODAY 186-89, II 10-13, available in WL I999 TNT I8689. 
The most influential argument against adopting CEN for U.S.based multinationals derives not only from economic considerations, but also from political ones: that CIN is necessary to preserve the competitiveness of U.S. multinationals vis-à-vis multinationals headquartered in other countries. ${ }^{160}$ For example, assume that a U.S. multinational competes with a German multinational in a host country that does not tax either foreign investor. If the United States taxes the U.S. multinational on its profits from the host country while Germany exempts the profits of its multinational, the U.S. multinational arguably faces a higher cost of capital and therefore a competitive disadvantage. ${ }^{161}$

Whatever the overall merit of this argument, ${ }^{162}$ it implicitly assumes that only unilateral, noncooperative action is possible in the field of international taxation. However, as the cooperative ventures discussed in Part V make clear, it is quite conceivable that all OECD members (a group that includes the home countries of about eightyfive percent of all multinationals) could be persuaded to adopt CENbased policies, which would address the competitiveness issue, at least in the short run. ${ }^{163}$ Thus, from the perspective of this Article, the competitiveness issue is irrelevant because the solutions discussed herein are all multilateral and are based on cooperative, concerted actions by the United States and its major trading partners.

To sum up, CEN still appears to be the best guide for taxing crossborder investment, including both portfolio investment and foreign direct investment. Neither the economic nor the political arguments against it are persuasive. Thus, to the extent that tax competition leads to the undertaxation of cross-border income as compared to domestic income, as described in Part II, CEN militates in favor of curbing such tax competition. However, as discussed below in section III.C, not all tax competition is equally harmful, and CEN should

\footnotetext{
160 See Frisch, supra note 72 , at 584-85; NFTC PROJECT, supra note 33 , II I.

161 However, if the German multinational sets its prices to maximize profits, it will charge the same as the U.S. multinational, and no competitive disadvantage need result. For a discussion of the conditions under which there may be a competitive disadvantage, see Susan Rose-Ackerman, Unfair Competition and Corporate Income Taxation, 34 STAN. L. REV. Io1 7 (1982); and Richard Steinberg, "Unfair" Competition by Nonprofits and Tax Policy, 44 NAT'L TAX J. 35 I (1991).

162 For a critique, see Frisch, supra note 72 , at 585-91. The fundamental problem with the competitiveness argument is its assumption that the welfare of U.S.-based multinationals is identical with U.S. national welfare. This assumption is problematic when all multinationals have both U.S. and foreign shareholders and employees. However, as Part II argues, ending deferral unilaterally might be counterproductive if it led new multinationals to incorporate their parents outside the United States and existing U.S. multinationals to become subsidiaries of foreign multinationals.

163 In the long run, such curbs on tax competition for OECD members may only lead to the rise of non-OECD-based multinationals. See infra pp. 1665-66. From a world welfare perspective, CEN clearly should apply to all multinationals, not just U.S. multinationals. Because of the difficulties in applying CEN on a residence basis, Part V develops a source-based approach to CEN.
} 
therefore be balanced against other considerations that favor allowing some forms of tax competition.

2. Welfare Economics and Public Choice. - In this section, I focus on the economic arguments for and against tax competition from a welfare economics perspective. The economic analysis of tax competition typically begins with Charles Tiebout's seminal I956 article, $A$ Pure Theory of Local Expenditures. ${ }^{164}$ Tiebout addresses the problem of providing public goods in a local-government context and shows that, in that situation, the problem of knowing true voter preferences for public goods and avoiding free riders is resolvable. ${ }^{165}$ The key to Tiebout's solution is the assumption that individuals can move between localities offering fixed but different levels of public services financed through benefits taxes. ${ }^{166}$ Tiebout shows that the optimal outcome in terms of satisfying individuals' preferences can be achieved because individuals will sort themselves geographically based on their differing preferences, paying different levels of benefits taxes, and the final outcome will not be inferior to market-based outcomes for private goods. ${ }^{167}$ The implication of Tiebout's analysis is that tax differentials among jurisdictions are socially desirable because they maximize the ability of individuals to satisfy their preferences and, therefore, that actions to harmonize tax rates are inefficient.

Tiebout's analysis depends on two crucial assumptions: first, that individuals are completely mobile between taxing jurisdictions; and second, that all taxes are benefits taxes and represent payments for goods and services provided by the government, rather than taxes based on people's ability to pay, which have distributive goals. ${ }^{168}$ When either assumption is relaxed, Tiebout's analysis becomes less accurate. ${ }^{169}$ At the international level, both of Tiebout's assumptions are problematic. As I argue above, restrictions on immigration impede individuals' ability to move between countries, and the main form of taxation is an income tax with explicitly distributive goals. Nevertheless, I argue below that Tiebout's analysis retains some validity at the

164 Charles M. Tiebout, A Pure Theory of Local Expenditures, 64 J. POL. ECON. 4 I6 (I 956).

165 See id. at $417-18,424$.

166 See id. at 418-19.

167 See id.

168 Another assumption, discussed below, is that one jurisdiction's provision of public goods creates no positive or negative externalities on other jurisdictions.

169 For a direct criticism of the Tiebout model in the international context, see Peggy B. Musgrave \& Richard A. Musgrave, Fiscal Coordination and Competition in an Intermational Setting, in MUNICH SYMPOSIUM, supra note 28, at 59, app. 8I-84 (I989) [hereinafter Musgrave \& Musgrave, Fiscal Coordination]. Even Charles McLure, who generally favors tax competition at the local level, see infra p. 1614 , admits that tax competition may be harmful at the international level because of distributive considerations and limited mobility. See McLure, supra note 28, at ror $\longrightarrow 2$. 
international level for generally applicable corporate tax-rate differentials among countries.

Following Tiebout, an extensive public finance literature focuses on tax competition at the local level, concentrating specifically on the types of taxes available to the local jurisdiction. As noted earlier, Tiebout's model assumes that jurisdictions levy only benefits taxes. What happens in jurisdictions that use distortionary taxes, such as taxes on capital, instead of benefits taxes or lump-sum taxes? George Zodrow and Peter Mieszkowski show that in such a case, the supply of public services will be less than optimal. ${ }^{170}$ They analyzed the supply of public services in a situation in which capital is mobile and the only options available to local government are a nondistorting lump-sum tax and a tax on capital (for example, a property tax). ${ }^{171}$ Under such circumstances, communities would levy only the head tax for fear that the tax on capital would drive out investment. However, if the head tax had to be reduced (for example, for political reasons), the level of public services would fall below the optimal level. ${ }^{172}$

Zodrow and Mieszkowski's analysis has generated several studies that focus on the negative effects of the tax competition that occurs when jurisdictions must tax a mobile factor, such as capital. For example, David Wildasin has reconceptualized the analysis as a fiscal externality: when a jurisdiction raises its taxes on capital, it causes a flow of capital to other jurisdictions that increases their tax revenues. Consequently, the first jurisdiction's desire to avoid the externality will lead to an insufficient supply of government services in that jurisdiction. ${ }^{173}$

170 See George R. Zodrow \& Peter Mieszkowski, Pigou, Tiebout, Property Taxation, and the Underprovision of Local Public Goods, I9 J. URB. ECON. 356, 368-69 (1986). The same result obtains when the government provides services to businesses as long as perceived capital responsiveness to changes in the tax on capital does not fall too drastically as the level of public services increases. The Zodrow and Mieszkowski model implicitly assumes that only capital is mobile between jurisdictions, which is a realistic assumption at the international level but not at the national level.

171 See id. at 358.

172 See id. at 368 .

173 See David E. Wildasin, Interjurisdictional Capital Mobility: Fiscal Externality and a Corrective Subsidy, 25 J. URB. ECON. I93, 194 (1989). A subsidy from a higher level of government can correct the inefficiency, but Wildasin shows that very high subsidy rates (on the order of $40 \%$ ) are needed. Obviously, at the international level there is at present no higher level of government to provide the subsidy. Wildasin also estimates the allocative inefficiency caused by inadequate local government spending; in his model, it could amount to $20 \%$ of spending at the margin. This estimate depends on the elasticity of demand for public goods. It also depends on the type of public goods involved. See Michael Keen \& Maurice Marchand, Fiscal Competition and the Patterm of Public Spending, 66 J. PUB. ECON. 33, 34-35 (I997) (showing that tax competition leads to the underprovision of public goods that benefit immobile consumers, such as recreational facilities, social services, or redistributional payments, and the overprovision of public goods that benefit mobile capital, such as infrastructure). If governments can compete by providing public goods to industry, 
Sam Bucovetsky and John Wilson have extended this analysis to situations in which a tax on wages, as well as a tax on capital, is possible. ${ }^{174}$ Because labor is relatively immobile, one could argue that taxes on wages would prevent the underprovision of public services that would otherwise result from the fear of driving capital elsewhere; such wage taxes would be like Pigouvian head taxes or Tieboutian benefits taxes. However, Bucovetsky and Wilson show that even with wage taxation, the supply of public services will continue to be inefficiently low because a tax on labor tends to reduce the labor supply in the taxing country. ${ }^{175}$ Capital will then flow out of the taxing country, and as a result, wages and labor supplies will rise in other countries, creating the same kind of positive externality as a tax on capital. ${ }^{176}$ Notwithstanding this analysis, Bucovetsky and Wilson also show that worldwide taxation of capital, if it were possible, would result in the efficient provision of public goods. ${ }^{177}$

If tax competition is harmful in these ways, why do countries not attempt to coordinate their tax policies? Studies by Wilson, Bucovetsky, and Ravi Kanbur and Michael Keen address this issue. ${ }^{178}$ These authors show that in a tax competition situation, the residents of smaller regions tend to benefit because small countries perceive capital elasticity to be higher and therefore undercut larger countries' tax rates. ${ }^{179}$ Thus, even if the combined tax revenue from both large and small regions would rise to the optimal level under a system of tax coordination, the residents of the smaller regions would object because they gain more from tax competition. The same political difficulties make restrictions on tax competition in the international setting less likely because smaller countries are more likely to be tax havens. ${ }^{180}$

Although most of the public finance literature has tended to favor restrictions on tax competition from a utilitarian perspective of welfare

curbing tax competition will require curbing such subsidies as well. See Clemens Fuest, Interjurisdictional Competition and Public Expenditure: Is Tax Co-ordination Counterproductive?, 52 FINANZARCHIV 478, 492-94 (I995). The OECD is, in fact, working on limiting such subsidies. See Marian Murphy \& Udo Pretschker, Public Support to Industry, OECD OBSERVER, Feb./Mar. I 997 , at I I, I 4 .

174 See Sam Bucovetsky \& John Douglas Wilson, Tax Competition with Two Tax Instruments, 21 REGIONAL SCI. \& URB. ECON. 333, 333-45 (I99I).

175 See id. at 342-43.

176 See id.

177 See id. at 345-49.

178 See S. Bucovetsky, Asymmetric Tax Competition, 30 J. URB. ECON. 167, 167-68 (1991); Ravi Kanbur \& Michael Keen, Jeux Sans Frontieres: Tax Competition and Tax Coordination When Countries Differ in Size, 83 AMER. ECON. REV. 877, 883 (I 993); John Douglas Wilson, Tax Competition with Interregional Differences in Factor Endowments, 2 I REGIONAL SCI. \& URB. ECON. 423, 424-26 (I99I); John Douglas Wilson, Theories of Tax Competition, 52 NAT'L TAX J. 269, 27879 (1999).

179 See, e.g., Kanbur \& Keen, supra note 178 , at 883.

180 Part V discusses the problem of tax havens. See infra pp. 1652-74. 
maximization, a different mode of analysis by public finance economists yields opposite results. A fundamental assumption of the studies cited above is that governments are benevolent - that they seek to maximize the utility of their residents. However, as the public choice literature shows, governments may also be considered Leviathans that seek to maximize their revenues in their own self-interest without regard for the good of the general citizenry. From this perspective, tax competition may be beneficial because it constrains governments' tendency to grow. ${ }^{181}$

In an influential article, ${ }^{182}$ which he wrote while serving as President Reagan's Deputy Assistant Secretary of the Treasury for Tax Policy, Charles McLure makes a forceful statement of the public choice perspective on tax competition. McLure criticizes the literature on tax competition and public finance for assuming that taxes must be levied on mobile capital. ${ }^{183}$ If governments can employ benefits taxes and individuals are mobile, the Tiebout analysis indicates that the problem of underprovision of public services will not arise. McLure then argues that at the state and local level, benefits taxes are both feasible and desirable. ${ }^{184}$ However, the core of McLure's argument is that "tax competition is, on balance, good" because it forces governments to be more attentive to the desires of voters, thus mitigating the Leviathan problem. ${ }^{185}$

The first prong of McLure's argument is problematic at the international level, given the limited mobility of individuals and the relevance of distributive concerns. ${ }^{186}$ However, the Leviathan prong has been quite influential. ${ }^{187}$ Most of the literature addressing this issue considers two questions: First, is either the Leviathan model or the benevolent model an accurate description of governments? Second, if governments are neither completely self-serving nor completely benevolent, what are the implications for tax competition?

On the first question, Wallace Oates has studied whether the extent of fiscal decentralization, which enables tax competition to take place,

181 The classic statement of this view comes from Geoffrey Brennan and James Buchanan. See Geoffrey BrenNan \& James M. Buchanan, The Power to TaX: ANALYTical FoundaTIONS OF A FISCAL CONSTITUTION I-33 (1980); Geoffrey Brennan \& James M. Buchanan, Tax Instruments as Constraints on the Disposition of Public Revenues, 9 J. PUB. ECON. 30I, 30I-18 (1978); Geoffrey Brennan \& James M. Buchanan, Towards a Tax Constitution for Leviathan, $8 \mathrm{~J}$. PUB. ECON. 255, 258-60 (1977).

182 Charles E. McLure, Tax Competition: Is What's Good for the Private Goose Also Good for the Public Gander?, 39 NAT'L TAX J. 34I (1986).

183 See id. at $341-43$.

184 See id. at $343-44$.

185 Id. at 346.

186 McLure himself agrees. See McLure, supra note 28, at I0I-02.

187 See, e.g., Fuest, supra note 173 , at 478-80; Musgrave \& Musgrave, Fiscal Coordination, supra note 169 , at 64 (responding to McLure). 
is negatively correlated with the size of the public sector, as the Leviathan model suggests, in forty-three countries (based on IMF data) and in the forty-eight contiguous U.S. states. ${ }^{188}$ In both cases, Oates finds no relationship between the degree of decentralization and the size of the public sector. Dani Rodrik advances a hypothesis that may explain this result: more open economies with more tax competition tend to correlate with more extensive social insurance programs because voters demand government insurance against the risks associated with an open economy. ${ }^{189}$ Thus, the empirical data are at best inconclusive and do not support the Leviathan model.

Jeremy Edwards and Michael Keen have directly compared the Leviathan and benevolent views of government from the perspective of tax competition. ${ }^{190}$ They point out that both views are extreme cases of a more plausible model, in which policymakers value both the welfare of their citizens and the surplus they extract from them for their own uses. ${ }^{191}$ Using the model developed by Zodrow and Mieszkowski (who assume that governments are benevolent), they ask whether tax competition is beneficial if policymakers act to maximize the welfare of citizens, if they act to maximize tax revenues, or if their goals fall somewhere in between.192 They show that if coordination leads to a small increase in the tax on mobile capital, the policymakers' welfare will unambiguously increase. ${ }^{193}$ The welfare of a representative citizen may also increase "if and only if the elasticity of the tax base exceeds the policy-maker's marginal propensity to waste tax revenue."194 For example, if it is estimated that the elasticity of capital to tax increases is 0.4 , then coordination is beneficial as long as government wastes less than forty percent of the capital tax revenue on bureaucrats rather than using it to benefit citizens. Edwards and Keen also show that the benefits of coordination are greater the higher one estimates the deadweight loss from taxation because coordination makes the tax closer to an unavoidable lump-sum tax. ${ }^{195}$ Thus, if the deadweight loss from the tax is thirty cents on the dollar, they calculate that coordination is desirable as long as an increase of revenues by

\footnotetext{
188 See Wallace E. Oates, Searching for Leviathan: An Empirical Study, 75 AM. ECON. REV. 748,750 ( 1985 ).

189 See Dani ROdRIK, Has Globalization Gone TOO FaR? 59-63 (I997) [hereinafter RODRIK, GLOBALIZATION]. This issue is discussed more extensively in section IV.A. See infra pp. I635-36.

190 See Jeremy Edwards \& Michael Keen, Tax Competition and Leviathan, 40 EUR. ECON. REV. I 13,1 I 4-I5 (1996).

191 See id. at 115 .

192 See id. at I I5-I6 (citing Zodrow \& Mieszkowski, supra note I 7o).

193 See id. at $122-23$.

194 Id. at 125.

195 See id. at 129.
} 
one dollar does not increase socially unproductive public expenditure by more than twenty-three cents.

Applying Edwards and Keen's analysis requires that one define and quantify government waste of tax revenue. However, their analysis indicates that even relatively low estimates of the elasticity of capital to taxation and of the deadweight loss from taxation require a very high estimate of government waste for the Leviathan model to be persuasive.

In sum, this perspective persuasively contends that undertaxation of cross-border capital flows is problematic from the standpoint of efficiency because it leads to deadweight losses. Such losses decrease global welfare and are unlikely (except under extreme assumptions regarding the extent of governmental waste) to be adequately compensated by benefits flowing from increased tax competition.

\section{B. Equity: The Tax Mix}

Equity in international taxation has two aspects: inter-individual equity and inter-nation equity. Inter-individual equity considerations determine the proper rate of taxation on cross-border transactions. ${ }^{196}$ Inter-nation equity considerations determine the proper division of the tax base among countries. ${ }^{197}$ In this section, I concentrate on the implications of inter-individual equity for determining proper tax rates; I consider issues of inter-nation equity in Part IV.

The following example illustrates the traditional inter-individual equity analysis of international taxation: Suppose individual $A$ earns roo in income from domestic sources while individual $B$ earns roo in income from domestic sources and 100 in income from foreign sources. Vertical equity requires taxing $B$ more than $A$ because $B$ has more income, but if foreign source income is excluded, $B$ and $A$ will be taxed the same. Thus, under-taxation of foreign source income is inconsistent with inter-individual equity.

196 Analysis of inter-individual equity usually proceeds in terms of horizontal and vertical equity, although some commentators have argued that the former is merely a subset of the latter. See Louis Kaplow, Horizontal Equity: Measures in Search of a Principle, 42 NAT'L TAX J. I39, I 43-44 (I989); Paul R. McDaniel \& James R. Repetti, Horizontal and Vertical Equity: The Musgrave/Kaplow Exchange, I FlA. TAX. REV. 607, 62 I (I993); Richard A. Musgrave, Horizontal Equity, Once More, 43 NAT'L TAX J. I I3, I I4 (I990). Although this distinction is not crucial for the following discussion, which focuses on the broader distributive consequences of undertaxing capital, the issue can be conceptualized as one of vertical equity.

197 See, e.g., Nancy H. Kaufman, Fairness and the Taxation of International Income, 29 LAW \& POL'Y INT'L BUS. 145 (1998); Peggy B. Musgrave, International Tax Base Division and the Multinational Corporation, 27 PUB. FIN. 394 (1972) [hereinafter Musgrave, International Tax Base Division]; Richard A. Musgrave \& Peggy B. Musgrave, Inter-nation Equity, in MODERN FISCAL IsSUES 63 (Richard M. Bird \& John G. Head eds., I972) [hereinafter Musgrave \& Musgrave, Internation Equity]. 
The problem with this argument, when couched in such general, impersonal terms, is that it disregards the parties' ability to respond to taxation by shifting the source of their income. Suppose, for example, that $A$ 's income is interest income that she can easily shift to a foreign income source, whereas $B$ 's domestic source income is labor income that she cannot so easily move. In that case, taxing $B$ the same as $A$ is not problematic from an equity perspective because $A$ can easily ensure that she pays less $\operatorname{tax}$ than $B$ by shifting the source of her income (or else other people will adjust their investments so that in equilibrium the after-tax returns to $A$ and $B$ will be equal). In that case, as Boris Bittker has shown, the equity violation turns into a violation of efficiency. ${ }^{198}$

The inter-individual equity argument requires a broader framework, one that takes into account the relative mobility of capital and labor. ${ }^{199}$ In general, as Part I argues, the present age of globalization can be distinguished from the preceding one (dating from 1870 to I9I4) by the fact that capital is much more mobile than labor. This higher mobility is the result of three historical changes that took place between I9I4 and I980. First, during the 1920s, all developed countries placed extensive restrictions on immigration, making large

198 See Boris I. Bittker, Equity, Efficiency, and Income Tax Theory: Do Misallocations Drive Out Inequities?, I6 SAN DIEGO L. REV. 735, 738 (1979).

199 This distinction is somewhat artificial in theory because all capital is earned at some point primarily from labor. Thus, economists would emphasize that the argument (with regard to the consumption versus the income tax) really concerns whether differential tax rates should be applied to future versus current consumption. However, given that most societies have a lopsided distribution of capital, and thus of income from capital, I consider it meaningful to distinguish between the majority of citizens who earn only labor income (many of whom cannot afford to save and therefore have no significant savings or income from savings at any point in their lives) and the small (in most countries) minority who earn significant income from capital. This distinction is particularly significant in the cross-border context because most capital investment overseas, and certainly most capital invested other than in widely held mutual funds (in which evasion is not an issue), is held by the richest segment of society. For example, a I997 survey found that, in the United States, $68 \%$ of all stock is held by the wealthiest $5 \%$ of households. See MARTHA STARRMCLUER, STOCK MARKET WeALTH AND CoNSUMER SPENDING I4 tbl.2 (Federal Reserve Bd. Fin. \& Ec. Discussion Series No. I 998-20, 1998), available at <http://www.bog.frb.fed.us/pubs/feds/ I 998/199820/I99820pap.pdf>. The income of that segment derives to a large extent from (previously accumulated) capital, not current labor. See Henry J. Aaron \& Alicia H. Munnell, Reassessing the Role for Wealth Transfer Taxes, 45 NAT'L TAX J. I19, I32, I30-32 (I992) ("[T]he role of bequests in wealth accumulation is clearly controversial and unresolved.... [T] that intergenerational wealth transfers are of sufficient size to establish a potential role for wealth transfer taxes to affect the distribution of wealth."); Anne L. Alstott, The Uneasy Liberal Case Against Income and Wealth Transfer Taxation: A Response to Professor McCaffery, I I TAX L. REV. 363,366 (1996). The half of American families whose annual incomes are below $\$ 50,000$ have less than $\$ 12,500$ in total financial assets and thus must depend almost entirely on labor earnings for survival. See Michael J. Graetz \& JerRy L. Mashaw, True Security: RethinkING AMERICAN SOCIAL INSURANCE 69 (1999). It is in this sense that the current discussion focuses on the relative undertaxation of capital income as a distributive issue. 
movements of labor in response to taxation very difficult. ${ }^{200}$ Second, during the rg8os, all developed and many developing countries relaxed their capital controls, reducing significant barriers to capital mobility. Finally, technological changes, from the development of electronic banking to the rise of the Internet, have made instantaneous, worldwide funds transfer possible. As noted above, international capital movements now approximate \$I trillion a day, a figure that exceeds the annual GDP of most countries.

Given these changes and the difficulty of taxing foreign source income from capital (as explained in Part $I I$ above), economists have predicted a shift from taxes on capital (the relatively mobile factor) to taxes on labor and land (the relatively immobile factors). ${ }^{201}$ Thus, the public finance literature's standard recommendation for small, open economies is to refrain from levying any taxes on capital because its mobility may result in the tax burden being shifted to domestic labor and land, which can be taxed directly with greater ease. ${ }^{202}$

Has there been such a shift from taxes on capital to taxes on labor? A good place to test this hypothesis would be the "tax mix," that is, the relative percentage of various types of taxes in total tax revenues, in OECD member countries from I 965 (before the relaxation of exchange controls) to the present. Table 2 summarizes the data from I 965 to I $995 .^{203}$

\footnotetext{
200 An exception is highly skilled labor, which migrates much more easily. Thus, tax competition raises the same issues for highly skilled labor as it does for capital. See, e.g., ASSAF RAZIN \& EFraIm SADKa, TAX Burden ÁND Migration: A Political EConomy Perspective 8 (National Bureau of Econ. Research Working Paper No. 5850, 1996); Jagdish N. Bhagwati \& John Douglas Wilson, Income Taxation in the Presence of Intermational Personal Mobility: An Overview, in INCOME TAXATION AND INTERNATIONAL MOBILITY I, 3 (Jagdish N. Bhagwati \& John Douglas Wilson eds., 1989). The following discussion assumes that highly skilled labor is akin to capital (which is realistic in the sense that it is hard to distinguish the return on capital from that on labor for entrepreneurs), and the equity analysis will focus on low-skilled labor.

201 See, e.g., TANZI, supra note 14, at 138-39; Gordon, supra note 35, at I I61; Tanzi, supra note 3 , at 27 .

202 See, e.g., Gordon, supra note 35, at I161; Razin, Sadka \& Yuen, supra note 33, at 2. This recommendation is modified if the taxes imposed by the host country can be credited in the home country. For a discussion of this issue, see below at section IV.B.2, p. I642 \& nn. 3I3-3I4

203 This table is taken from Jeffrey Owens \& Jacques Sasseville, Emerging Issues in Tax Reform 9 tbl. I (Oct. I 997) (unpublished manuscript presented at the Joint IFA/OECD Seminar, New Delhi, India, on file with the Harvard Law School Library). For more detailed data for the period from I 975 to I 992, including figures for non-OECD members, see Asegedech WoldeMariam, Summary Tax Structure Tables, 1975-92, in TAX POLICY HANDBOOK app. (Parthasarathi Shome, International Monetary Fund, ed., 1995).
} 
TABLE 2. STRUCTURE OF TAXATION IN

OECD COUNTRIES, I965-95

(percentage of total revenues)

\begin{tabular}{|c|c|c|c|c|c|c|c|c|}
\hline Type of Tax & I965 & 1970 & 1975 & 1980 & 1985 & Ig9o & I994 & I995 \\
\hline $\begin{array}{l}\text { Personal } \\
\text { income }\end{array}$ & 26 & 28 & 30 & $3 I$ & 30 & 29 & 27 & 27 \\
\hline $\begin{array}{l}\text { Corporate } \\
\text { income }\end{array}$ & 9 & 9 & 8 & 8 & 8 & 8 & 8 & 8 \\
\hline $\begin{array}{l}\text { Social } \\
\text { security }\end{array}$ & I8 & 20 & 22 & 22 & 22 & 23 & 25 & 25 \\
\hline Property & 8 & 7 & 6 & 5 & 5 & 6 & 6 & 5 \\
\hline $\begin{array}{l}\text { General } \\
\text { consumption }\end{array}$ & 12 & I4 & I3 & I4 & I6 & I7 & I8 & 18 \\
\hline $\begin{array}{l}\text { Other goods } \\
\text { and services }\end{array}$ & 26 & 22 & I9 & I8 & I8 & I4 & I5 & 15 \\
\hline
\end{tabular}

These data suggest the following conclusions. First, the data should be interpreted in light of an overall tendency for government revenues to grow as a percentage of GDP, not only in OECD member countries, but also in most developing countries. ${ }^{204}$ This trend has continued in OECD member countries, whose average government revenues reached $37.6 \%$ of their GDP in $1994 .^{205}$ However, the rate of growth has been considerably less steep in the I980s and early I990s than in the I970s. ${ }^{206}$ As Part IV discusses, the overall growth in the tax burden can be explained by the growing role of the state in providing social insurance. The slower recent growth can be explained by the political and practical obstacles to raising taxes to expand social insurance programs. The growth in overall government revenues signifies that the $25 \%$ of total revenues attributed to social security (payroll) taxes in 1995 represents a significantly higher percentage of GDP

\footnotetext{
204 Between the period from 1975 to 1980 and the period from 1986 to 1992 , the unweighted average of the percentages of GDP represented by OECD countries' tax receipts rose from $30 \%$ to $34.3 \%$. See WoldeMariam, supra note 203 , at 289 tbl.1, 293 tbl.5. The same periods saw increases in the unweighted average from $20.5 \%$ to $21.7 \%$ in African countries, see id. at 295 tbl.7, 299 tbl.I I; from $16.6 \%$ to $18.9 \%$ in non-OECD Asian countries, see id. at 301 tbl. 13,303 tbl. 7 ; and from $19.3 \%$ to $19.7 \%$ in non-OECD Western Hemisphere countries, see id. at 307 tbl.25, 31 I tbl.29. Only in Middle Eastern countries was there a decline (from $37.5 \%$ to $28.3 \%$, which includes nontax oil revenues, but tax revenues also declined from $15.7 \%$ to $13.6 \%$ ). See id. at 304 tbl.19, 306 tbl.23.

205 See Owens \& Sasseville, supra note 203 , at 7 . For a sample of industrialized countries (the European countries, Canada, Japan, and the United States), government expenditures reached an average of $49 \%$ of GDP in I994. See RODRI, GLOBALIZATION, supra note 189 , at 50 tbl.4.I.

206 See Owens \& Sasseville, supra note 203 , at 8 fig.I.
} 
than the $26 \%$ of total revenues attributed to taxes on "other goods and services" (such as excise taxes and tariffs) in 1965 .

Second, the data in Table 2 indicate that revenues from both the corporate and personal income taxes have remained steady as a percentage of total tax revenues (although they have risen in absolute terms, as have total revenues). In OECD member countries, revenues from the personal income tax were $26 \%$ of total tax revenues in 1965 and $27 \%$ in $1995 .{ }^{207}$ Revenues from the corporate income tax in the same years were $9 \%$ and $8 \%$ respectively. ${ }^{208}$ Although the corporate income tax is more important than the individual income tax in developing countries, the same flat relation holds for those countries as well. ${ }^{209}$ However, because the income tax reaches both labor and capital, this flat relation may mask a shift in the tax burden from capital to labor. ${ }^{210}$ The flatness is striking because in most OECD member countries, tax rates have gone down in recent years. ${ }^{211}$

207 See id. at 9 tbl.I. This flatness masks a slight rise in the late 1970 (to a peak of $31 \%$ in 1980 ) and a subsequent decline. See $i d$.

$208 \mathrm{See}$ id. This average masks considerable inter-country variation. For example, in New Zealand, revenues from the individual income tax declined from $62.6 \%$ of total tax revenues for the period from 1975 to 1980 to $53.6 \%$ for $I 986$ to 1992 , while revenues from the corporate income tax declined from $10.8 \%$ to $8.3 \%$. See WoldeMariam, supra note 203 , at 290 tbl.2, 294 tbl.6. In the United States, revenues from the individual income tax stayed flat during those periods, at $46.6 \%$ for 1975 to 1980 and $46.1 \%$ for I 986 to 1992 , while revenues from the corporate income tax declined from $14.7 \%$ to $9.8 \%$. See id.

209 In African countries, revenues for the individual income taxes from I 975 to I 980 and I 986 to I 992 represented $10.2 \%$ and I I.4\% of total tax revenues, respectively, while the figures for the corporate income tax were $17.5 \%$ and $17.1 \%$. See WoldeMariam, supra note 203, at 296 tbl.8, 300 tbl.12. A small decline in revenues can be observed in non-OECD Asian countries over the same time spans (from $15.4 \%$ to $14.7 \%$ in the individual tax and from $19.7 \%$ to $16.9 \%$ in the corporate tax). See id. at 301 tbl.14, 303 tbl.r8. In non-OECD Western Hemisphere countries during these years, there was a small decline in the individual tax's percentage (from $8.5 \%$ to $6.4 \%$ ) and a small rise in the corporate tax's (from $13.2 \%$ to $14.0 \%$ ). See id. at 308 tbl.26, 310 tbl. 28 .

210 The individual income tax typically reaches income from both labor and capital, but the tax rate on capital, even in developed countries, varies greatly with the type of asset. See Jeffrey Owens, Tax Reform for the 2Ist Century, 14 TAX NOTES INT'L 583, 591 (I997) (calculating effective tax rates on pensions, housing, equities, and certificates of deposit for OECD members). For I 983, Gordon and Slemrod have calculated that the United States collected no tax on capital. See Roger H. Gordon \& Joel Slemrod, Do We Collect Any Revenue from Taxing Capital Income?, in 2 TAX POLICY AND THE ECONOMY 89, 89 (Lawrence H. Summers ed., I 988 ). However, the changes made in the 1986 Act may have modified this analysis. The incidence of the corporate income tax is notoriously hard to assess; a recent estimate has put it in the long run as partly falling on capital and partly on labor, see U.S. DEP'T OF THE TREASURY, INTEGRATION OF THE INDIVIDUAL AND CORPORATE TAX SYSTEMS: TAXING BUSINESS INCOME ONCE 32 1-26 (I 992). This incidence may shift with changes in market conditions, including globalization. See Arnold C. Harberger, The Incidence of the Corporation Income Tax, 70 J. POL. ECON. 2 I5, 2 I6 (I962) (basing the conclusion that the incidence is on all capital on a closed-economy model). See infra section IV.B.3, pp. I64748 (discussing incidence and its implications).

211 See CHENNELLS \& GRIFFITH, supra note 128, at 31-35; Owens \& Sasseville, supra note 203, at II; Owens, supra note 2 IO, at 585-86. 
Third, both OECD member countries and developing countries have seen a rise in taxes on consumption, which are usually considered taxes on labor. In OECD member countries, general consumption tax, or value-added tax (VAT), revenues rose from i2\% of total tax revenues in 1965 to $18 \%$ in $1995 .{ }^{212}$ In developing countries, general consumption taxes rose from $25.5 \%$ of total tax revenues for the period from 1975 to 1980 to $31.8 \%$ for the period from 1986 to 1992 . Most of this increase can be explained by a rising tax rate. Jeffrey Owens and Jacques Sasseville show that almost every OECD member country that has a VAT (all OECD members except the United States) has raised the standard rate since the tax was introduced. ${ }^{213}$

Fourth, OECD member countries have increased their payroll (social security) taxes to fund social insurance programs, from I $8 \%$ of total tax revenues in 1965 to $25 \%$ in $1995^{214}$ The majority of OECD member countries raised more revenue in 1995 from social security taxes than from the income tax. ${ }^{215}$ This trend can be explained by the expansion of social insurance programs, as a result of the aging population, and by increases in unemployment benefits, which are discussed in Part IV. ${ }^{216}$

These four conclusions come together as follows: From I 965 to I995, governments all over the world increased substantially the percentage of GDP collected as tax revenues. As revenues from both the individual and corporate income taxes have been generally flat - as a percentage of total revenues - over this period, the increase in total tax revenues was financed by increases in consumption taxes in all countries and in payroll taxes in developed countries. Because both consumption taxes and payroll taxes fall on labor, whereas income taxes may be imposed on both labor and capital, the data are consis-

212 To some extent, this rise was offset by a decline in revenues from tariffs and excises (classified as other goods and services), but given the rise in overall government revenues, it represents a significant increase in the tax burden.

213 The only exceptions are Canada and Switzerland, which only introduced the VAT in the I990s. See Owens \& Sasseville, supra note 203, at I2 \& tbl.4. Australia will introduce a VAT on July I, 2000, see Tom Allard, Senate Ticks GST, and Prices Are on the Way Dorm, SYDNEY MORNING HERALD, June 29, I999, at I, available in 1999 WL 19376199, leaving the United States as the only OECD member without a VAT, see Jeffrey Owens, What Chance for the Virtual Taxman?, OECD OBSERVER, Oct./Nov. 1997, at I6, I 7-I8.

214 See Owens \& Sasseville, supra note 203 , at 9 tbl.I. The rise between the periods from 1975 to 1980 and from $\mathrm{I} 986$ to $\mathrm{I} 992$ was less pronounced (from $24.9 \%$ to $25.6 \%$ ), see WoldeMariam, supra note 203 , at 290 tbl.2, 292 tbl.4, which suggests that most of the rise took place in the early 19705 .

215 See Owens \& Sasseville, supra note 203 , at 13.

216 See infra pp. 1632-33, I638. Payroll taxes are less important in developing countries, where government employment and government spending on general programs are more significant than direct social insurance. In non-OECD countries, payroll taxes tended to remain flat between the periods from $I 975$ to $I 980$ and from $I 986$ to $I 992$. 
tent with the shift from taxing capital to taxing labor predicted as a consequence of globalization.

In addition, more specific data on trends in income taxation suggest that the effective tax rate on income from capital may be declining. Effective tax rates can be measured in three ways. First, the model developed by Mervyn King and Don Fullerton calculates a country's effective marginal tax rate (EMTR), the difference between the pretax and the post-tax rates of return for the marginal investment, by using a simulated investment project and by assuming certain inflation and interest rates. ${ }^{217}$ Second, a similar model yields the effective average tax rate (EATR), the difference between the project's value in the absence of tax and its value in the presence of tax. ${ }^{218}$ The EATR is relevant for a project that earns some economic rent, as most projects financed by multinationals do. Finally, another mode of computation of effective tax rates attempts to calculate the actual average tax rate (ATR) based on financial data published by firms in their financial accounts. The ATR differs from the EMTR and EATR in that it is based on actual firm-level data and not on hypothetical assumptions. ${ }^{219}$ The quality of the data available for ATR calculations, however, varies greatly from country to country. 220

The virtue of all three methods is that they take into account both changes in the statutory tax rate and changes in the tax base. Thus, if tax reform leads to a reduction in the statutory rate that is offset by widening the tax base, as most I980s-era tax reforms in OECD member countries aimed to do, effective tax rates should remain unchanged. ${ }^{221}$ Lucy Chennells and Rachel Griffith report the results from calculating EMTRs, EATRs, and ATRs for a sample of ten OECD member countries over the period from 1979 to $1994 . .^{222}$ They find that domestic EMTRs declined from an average of $21.7 \%$ in 1979 to $20.5 \%$ in $1994 .{ }^{223}$ Similarly, domestic EATRs, which are more relevant for foreign direct investment, declined over the same period from $21.7 \%$ to $17.9 \% .{ }^{224}$ Finally, ATRs based on actual accounting data for six of the countries - Australia, France, Germany, Japan, the United

217 See CHENNELlS \& GRIFFITH, supra note I28, at 37, 40 (citing THE TAXATION OF INCOME FROM CAPITAL: A COMPaRative STUdY OF THE UNITED STATES, THE UNITED Kingdom, SWEDEN, AND West GermaNY (Mervyn King \& Don Fullerton eds., I984)).

218 See id. at 38.

219 See id. at $40-41$.

220 Most ATR calculations are based on the income tax footnote as summarized in the COMPUSTAT database and represent the ratio of the net provision for current taxes to net pretax income. Data based on tax returns are superior but are not usually available.

221 For an overview of tax reforms in the I980s, see CHENNELIS \& GRIFFITH, supra note I28, at 26-30.

222 See ChENNELLS \& GRIFFITH, supra note 128 , at 1 .

223 See id. at 46 tbl.4.2.

224 See id. at 53 tbl.4.4. 
Kingdom, and the United States - declined from $40.0 \%$ in 1985 to $32.6 \%$ in 1994.225 Because these calculations are based on corporate income taxes, they can be assumed to fall on income that is mobile relative to labor income. ${ }^{226}$

Harry Grubert's data, based on actual tax returns, offer further confirmation of this decline in effective corporate tax rates. ${ }^{27}$ Grubert studied changes in the average effective tax rates in a sample of sixty countries for the period from I 984 to 1992 and supplemented the sample with published financial data for the years after 1992 . He found that ATRs fell from $32.9 \%$ in 1984 to $23 \%$ in $1992 .{ }^{228}$ Statutory rates also fell, but by less than did effective rates - from 4 I. $2 \%$ to $33.4 \% .229$ Moreover, the decline in ATRs was largest in countries with a population of less than 15 million, which are likely to be more sensitive to capital flows, and smallest in countries with more restrictions on capital flows. Thus, the data are consistent with the hypothesis that capital mobility may be driving down effective rates on income from capital. ${ }^{230}$

Rodrik has calculated unweighted average effective tax rates on capital and labor for France, Germany, the United Kingdom, and the United States for the period from 1970 to $1991 .{ }^{231}$ The data indicate that taxes on both capital and labor in those countries went up in tandem from I970 until about 198I, but that since then, taxes on capital have gone down while taxes on labor have continued to rise. ${ }^{232}$

Finally, a series of studies has used data from national income accounts to calculate tax rates. The advantage of this method is that it uses actual revenues to compute effective tax rates on consumption,

\footnotetext{
225 See id. at 63 tbl.4.6.

226 Chennells and Griffith argue that their data do not exhibit tax competition because there is little evidence of convergence. See id. at 80 . But, as noted above in Part II, until taxes reach o\%, tax competition can lead to a general downward trend without any convergence taking place. See supra note 67.

227 See Grubert, supra note 67. Grubert uses Form 547 I, which a corporation files for every CFC and which includes foreign taxes paid and net income reported. See id. at 8.

228 See id. at 30 tbl.8.

229 See id.; see also Altshuler, Grubert \& Newlon, supra note 63, at I I (finding a decline of more than $15 \%$ in ATRs and a $14 \%$ drop in statutory tax rates between 1984 and 1992 , which indicate rate reductions that were not compensated for by base-broadening).

230 Grubert notes that there was little convergence and that reductions in tax were lower in the $\mathrm{EU}$ and argues that these points militate against the tax competition explanation. See Grubert, supra note 67 , at 17-18. But as I explain above, tax competition does not imply convergence, see supra note 67 , and EU tax rates may have been kept up by the need to fund generous social insurance programs, see infra p. I634. As I explain below in Part IV, however, this ability to tax capital to fund social insurance may not last. See infra pp. 1633-34.

231 See RODRIK, GLOBALIZATION, supra note 189 , at 63-64.

232 See id. at 65 fig.4.4.
} 
capital, and labor separately. ${ }^{233}$ Mendoza, Razin, and Tesar calculated tax rates for the $G_{7}$ countries from $I_{965}$ to $I 988$ and found that although taxes on consumption and capital income tended to be stationary, ${ }^{234}$ "the tax rate on labor income has followed an increasing trend in all countries."235 In another study, Mendoza and his colleagues used the same methodology to calculate tax rates for eighteen OECD member countries for the period from 1965 to $199 \mathrm{I} .^{236}$ They then calculated a regression relating those data to a measure of "lagged openness," defined as the sum of imports plus exports divided by total output in the economy for the previous year. ${ }^{237}$ They found that taxes on labor respond positively to increases in lagged openness while taxes on capital respond negatively. ${ }^{238}$ That is, as an economy becomes more open to capital flows, it tends increasingly to shift the tax burden from capital to labor.

What are the equity implications of these data? Because labor is generally less mobile than capital, a decline in taxes on capital and a rise in taxes on labor usually involves a change in the tax burden that cannot be offset by income shifting and that therefore tends to violate vertical equity. More broadly, because the rich save more than the poor, taxes on labor, such as consumption and payroll taxes, are generally more regressive than taxes on capital or on savings. Thus, a shift in the tax burden from capital to labor tends to render the tax system more regressive. Such a tax system is also less capable of redistributing resources from the rich to the poor. ${ }^{239}$ As a result, the overall distribution of income in a society tends to become more inequitable

233 For this purpose, taxes on consumption comprise general taxes on goods and services and excise taxes. Taxes on labor comprise the portion of the individual income tax that falls on wages, social security taxes - both employee and employer portions - and payroll taxes. Taxes on capital comprise the portion of the individual income tax that falls on non-wage income, corporate income taxes, property taxes, and taxes on financial transactions.

234 See Enrique G. Mendoza, Assaf Razin \& Linda L. Tesar, Effective Tax Rates in Macroeconomics: Cross-Country Estimates of Tax Rates on Factor Incomes and Consumption, $34 \mathrm{~J}$. MONETARY ECON. 297, 307-08, 306 tbl.I, 308 tbl.3 (1994).

235 Id. at 308; see also id. at 307 tbl.2.

236 See EnRique G. Mendoza, Gian Maria Milesi-FerRetti \& Patrick Asea, ON the INEFFECTIVENESS OF TAX POLICY IN ALTERING LONG-RUN GROWTH: HARBERGER'S SUPERNEUTRALITY CONJECTURE 4 (Centre for Econ. Policy Research Discussion Paper No. 1378, 1996). These countries are Australia, Austria, Belgium, Canada, Denmark, Finland, France, Germany, Italy, Japan, the Netherlands, New Zealand, Norway, Spain, Sweden, Switzerland, the United Kingdom, and the United States. See id. at I8.

237 See DANI RODRIK, THE NEW Global ECONOMY AND DEVEloping CoUNTRIES: MAKING OPENNESS WORK 28 fig.2.I, 24-40 (I 999).

238 See MENDOZA, MILESI-FERRETTI \& ASEA, supra note 236 , at 28-29.

239 A graduated consumption tax of the cash flow type can be progressive, but this phenomenon does not apply to the VAT, which typically has only one or two rates. In addition, the exclusion of income from savings from the tax base means that in most plausible scenarios, even a cash flow consumption tax will be less progressive than the income tax. Payroll taxes tend to be regressive because they are typically proportional and capped at a certain level of income. 
compared to a proportional distribution, as measured by the Gini coefficient. ${ }^{240}$

The range of before-tax incomes widened in the I980s and I990s in several OECD countries, including the United Kingdom and the United States. Given the alterations in tax patterns surveyed above, this development means that the change in after-tax distribution of income is likely to be greater with an increase in the Gini coefficient. ${ }^{241}$ This pattern is not limited to OECD member countries. The evidence from Latin America indicates that as countries have opened their borders, income inequality has tended to rise. ${ }^{242}$ For example, in Chile, which led the trend of Latin American trade and investment liberalization, the Gini coefficient rose from 0.46 in 1971 to 0.58 in 1989 , one of the largest jumps ever witnessed in a single country over such a short period of time. ${ }^{243}$

As capital mobility has increased since the relaxation of exchange controls in the early I980s, taxes on capital have tended to decrease and taxes on labor to increase in both developed and developing countries. Because labor is less mobile than capital, it is generally not able to turn the inequity into an efficiency by moving to countries with lower tax rates. Moreover, because capital income accrues disproportionately to the rich, the shift in tax burden from capital to labor has tended to make all societies less equitable in terms of the distribution of income or wealth. Remedying this situation calls for finding ways to tax capital despite its relatively high mobility. These methods will be explored in Part $\mathrm{V}$.

\section{Democracy: Two Types of Tax Competition}

The preceding two sections have focused on the ways in which tax competition on income from capital can be harmful: It can lead to an inefficient global allocation of capital. It can also force governments to use relatively regressive forms of taxation and limit their ability to use taxes on capital for redistributive purposes. These efficiency and equity considerations all support the conclusion that tax competition should be limited.

240 The Lorenz curve is the relationship between the percentage of income and the percentage of individuals in a society. A straight Lorenz curve implies that the distribution of income in a society is completely equal, meaning that the bottom $50 \%$ of the people has $50 \%$ of the income. The Gini coefficient is the ratio of the area above the Lorenz curve to that below the diagonal. A zero Gini coefficient indicates complete equality; a Gini coefficient of $\mathrm{I}$ means that all income accrues to one individual, or that income is distributed in a completely unequal way. See Howell H. Zee, Taxation and Equity, in TAX POLICY HANDBOOK, supra note 203, at 30, 32.

241 See Owens \& Sasseville, supra note 203 , at 35.

242 See generally DANI RODRIK, THE NEW GlOBAL ECONOMY AND DEVELOPING COUNTRIES: MAKING OPENNESS WORK I 3-1 4 (I999) [hereinafter RODRIK, NEW GLOBAL ECONOMY].

243 See id. at 14. 
However, these considerations must be balanced against another: Tax competition can reflect the divergent preferences of citizens of democracies for particular government sizes. In fact, the level and type of taxation are among the most important decisions made by voters in democracies, and those decisions provide an image of the society citizens prefer. From a welfare economics perspective, tax competition is beneficial to the extent that it reflects these voter preferences. Thus, it is necessary to inquire whether it is possible to distinguish between types of tax competition that are likely to reflect such preferences and those that are less likely to do so. A clear case can be made for limiting the latter type of tax competition; the case for limiting the former type - tax competition that reflects preferences for the desirable size of government - is more problematic.

We can start with the Tiebout model, in which tax competition or at least differences in tax rates among jurisdictions, as Tiebout assumes that the rates are fixed - is beneficial because it enables citizens to maximize their welfare by moving to the jurisdiction that reflects their personal tax preferences. ${ }^{244}$ On its face, this model is inapplicable to the problem that lies at the heart of this Article - the problem of how to tax mobile capital in an open economy - because on the international level individuals cannot easily move from one country to another and because taxes are used to redistribute wealth as well as to pay for government goods and services.

However, the Tiebout model remains useful to consideration of international tax competition. First, even though citizens cannot move from country to country, they can vote in democratic countries, and given the salience of the tax issue in politics, it seems likely that their votes actually affect the level of government taxation and spending. ${ }^{245}$ Thus, one can envisage a situation in which the world is divided into jurisdictions with different levels of public spending, each of which depends on the wishes of the majority of each country's citizens.

Second, the focus in tax competition has been on source-based corporate taxes. ${ }^{246}$ These taxes are much closer to the benefits taxes Tie-

244 See Tiebout, supra note 68 , at 418.

245 The level and form of taxation have been crucial issues in recent elections in Australia, Canada, Japan, and the United States. See, e.g., Richard J. Vann \& Graeme S. Cooper, Report of Australia's Business Tax Review and the Government's Response, I 999 WORLDWIDE TAX DAILY I9I-6, available in WL I999 WTD I9I-6; Larry M. Greenberg, Canadian Elections Promise Acid Test on Lower Taxes or Improved Services, WALL ST. J., June 2, 1999, at A2 I; Hold On, Japan's Busy, ECONOMIST, Sept. 12, I998, at 39; Alison Mitchell, Republicans Looking Right and Left for the Best Tax Cut Plan, N.Y. TIMES, Mar. 22, 1999, at Ar3.

246 Source-based taxation on portfolio income of individuals is also at issue, but only as a backstop for residence-based taxation; if residence-based taxation of individuals could be ensured, no problem would arise, even if tax competition meant zero source-based taxation. For corporations, however, residence-based taxation is implausible, as Part V argues. See infra p. 1666 \& n. $45 \mathrm{I}$, pp. I670-7I. A different type of benefit analysis applies to individual investors: those investors who 
bout described than is generally recognized. They are not a significant factor in redistribution; in fact, their incidence is both unknown and possibly inconstant from year to year. Instead, they represent both a payment to the source country for the costs it incurs to enable investment by a multinational and a way of ensuring source countries, particularly developing source countries, an adequate tax base. ${ }^{247}$

This leads to an important distinction: If a multinational invests in a country with a small public sector, it will probably have to incur more costs or earn lower profits than if the public sector were larger. For example, it may have to invest in training for its workers because the government provides inadequate public education, or it may have to build its own transportation systems because the government does not supply adequate infrastructure. In that case, it would be inappropriate to penalize the multinational by taxing it at a higher rate such as its home-country rate - to offset the lower taxes levied by the host country. ${ }^{248}$ If the multinational faces lower profits, the incentive to locate in the low-tax country would be limited, and therefore the negative effects of tax competition would be curtailed as well.

But this argument holds true only if the public sector is smaller as a result of a generally applicable tax decrease. If, on the other hand, the government decides to maintain high taxes on immobile factors, such as labor and land, and to grant the multinational a targeted tax holiday, or equivalently to subsidize it with targeted expenditures on training and infrastructure, the multinational reaps a windfall. Having made the decision to invest somewhere, the multinational can then choose the location that offers it the best tax and subsidy package, aware that because the general level of taxation on domestic labor and land is high, it will not have to incur additional costs.

Thus, this line of analysis suggests a distinction between generally applicable tax decreases that reduce the overall size of the public sector and tax decreases or subsidies that are limited only to foreign investors. In the former case, the tax reduction represents the wishes of the electorate and does not confer a windfall on foreign investors. In the latter case, the electorate is unlikely to be involved, because tax holidays to foreign investors are rarely the subject of political attention

reside in high-tax countries but earn untaxed overseas income free-ride on the benefits provided by the high-tax country, that is, they do not pay the price of civilization.

247 For an argument that source-based corporate income taxation is correlated with costs imposed, see Avi-Yonah, Intermational Taxation of Electronic Commerce, supra note 40, at 520-2I. For a discussion of the inter-nation equity rationale for allowing developing countries to tax multinationals, see below at Part IV.

248 Although the tax paid by the multinational in its home country would be lower to the extent that its deductible costs in the low-tax country are higher, this decrease is the equivalent of granting a deduction rather than a credit for the forgone host-country tax. It would not compensate the multinational for its lower profit. 
even if they are made public. ${ }^{249}$ Moreover, the tax holiday represents a windfall to the multinational because the multinational benefits from a large public sector financed by high, generally applicable taxes.

The same distinction can also be made from a Leviathan perspective, under which overall tax reductions may be beneficial, especially if they stem from the voters' mandate and if they result in smaller governments. By contrast, targeted incentives aimed at foreigners do not produce similar positive effects, as the reductions' relative size is too small to affect the overall size of government. In fact, targeted tax incentives can themselves be seen as a form of government waste: they enable elected officials to boast about job creation in the short run without engaging in an adequate cost-benefit analysis of the revenues lost in the long run. ${ }^{250}$ The costs of targeted tax incentives - lost revenues and congestion problems - are likely to be less salient politically than the immediate benefits from job creation, especially when unemployment is a central political issue.

I suggest, therefore, that the line between beneficial and harmful tax competition be drawn between general tax reductions that apply to all taxpayers, domestic and foreign, and targeted tax reductions that are granted only to foreign investors. Under this definition, harmful tax competition includes both production and headquarters tax havens, because these are typically granted only to foreign multinationals. It also includes reductions in withholding taxes that are aimed solely at attracting foreign capital, unless measures are taken to ensure residence-based taxation. ${ }^{251}$ Finally, harmful tax competition includes traditional offshore tax havens with a low or zero tax rate, if the tax base is confined almost entirely to foreign investors. ${ }^{252}$ Such investors have no real business operations in the tax haven and therefore suffer no detriment from the small size of the public sector. However, harmful tax competition does not include overall reductions in the tax rate that apply to all taxpayers in a jurisdiction when the tax base includes significant numbers of domestic taxpayers.

249 A rare exception to this rule is the benefit package that Alabama granted Mercedes-Benz, which was widely criticized because the dollar amount of incentive per job created was three times the amount any state had previously paid to a foreign investor. This affair became an election issue and contributed to Governor Jim Folsom's 1994 defeat. See Allen R. Myerson, $O$ Governor, Won't You Buy Me a Mercedes Plant?, N.Y. TIMES, Sept. I, 1996, § 3, at I.

250 Most studies of targeted tax benefits designed to attract investment in both the state and international context have found that, although these benefits are effective in attracting the investment, see supra pp. 1590-9I; infra pp. 1643-44, the returns to the host country are insufficient in the long run to compensate for the lost revenues, see supra pp. I601-02; infra pp. 1646-47.

251 Because individual income taxes should be levied primarily by the home country, reducing withholding taxes is acceptable if residence-based taxation is ensured.

252 "Almost entirely" requires a definition: perhaps a tax incentive of $90 \%$ or more, the benefits of which redound to foreigners, would qualify. Traditional tax havens would generally cross this line. Although one can imagine marginal cases, the distinction would be clear in most situations. 
A possible objection is that the preceding sections' arguments against tax competition on efficiency and equity grounds apply to all forms of tax competition, not just to harmful tax competition as defined above. After all, a generally applicable tax decrease, which I exclude from the definition of harmful tax competition above, can draw a large flow of capital from one country to another and result in an inefficient allocation of capital and in limitations on the home country's ability to redistribute income equitably.

However, as noted above, such considerations need to be balanced against the ability of voters in democratic countries to determine the desirable size of their public sector, even if this approach has potential adverse consequences for other countries. This judgment is both a normative and a practical one: as the failed attempts to impose minimum tax rates in Europe show, countries are highly reluctant to give up their right to set generally applicable tax rates, because that right is a core attribute of sovereignty. ${ }^{253}$ However, they would be more likely to relinquish their right to target tax incentives at foreigners if they knew that the main reason for granting the incentive was fear that the capital would otherwise flow to another country that grants such incentives. In this kind of assurance game situation, multilateral action can achieve the best outcome for all concerned..$^{254}$

The distinction that I propose between harmful and beneficial tax competition can be illustrated by two examples drawn from recent U.S. history. Ronald Reagan was elected president in 1980 on the basis of explicit promises to reduce the size of the federal government and to cut taxes. In I98I, he fulfilled the latter pledge by signing the largest individual and corporate tax decrease in U.S. history. In particular, the adoption of the accelerated cost recovery system (ACRS) and an investment tax credit (ITC) meant that new capital investment by corporations would be more than expensed, resulting in negative tax rates on normal corporate profits. This result, in turn, led to a proliferation of tax shelters for individuals, so that in I 983 , according to Gordon and Slemrod, the United States collected no net tax whatsoever on capital income. ${ }^{255}$

\footnotetext{
253 In 1975, the European Commission proposed a directive for uniform minimum and maximum corporate tax rates. The Council never adopted the directive, which was withdrawn in 1990. See Commission Communication to Parliament and the Council, Guidelines on Company Taxation (SEC 9o/06or final, Brussels, Apr. 20, 1990) (withdrawing Corporation Tax Directive, COM(75)392 final). The Ruding committee made a similar proposal, see RUDING REPORT, supra note I9, at 202, which was never seriously considered.

254 For a more detailed discussion of how such cooperative outcomes can be implemented, see below at Part V.

255 See Gordon \& Slemrod, supra note 210 , at 89 . The I 981 tax cuts were partially reversed in 1982. See Tax Equity and Fiscal Responsibility Act of I982, Pub. L. No. 97-248, tits. II-IV, 96 Stat. 324, 4 I I-671. The Tax Reform Act of 1986, Pub. L. No. 99-5 14, 100 Stat. 2085, largely elimi-
} 
The Economic Recovery Tax Act of I98 I (ERTA), 256 together with the Reagan defense buildup, also caused a burgeoning budget deficit. A flow of foreign capital into the United States, at least in part the direct result of lower tax rates, financed this deficit. Hans-Werner Sinn estimates that the ACRS and ITC generated a flow of between $\$ \mathrm{r}$ trillion and \$I.5 trillion, or seven percent of the world's capital stock at that time, into the United States from I98I to I $984 . .^{257}$ This influx of foreign capital was predictable because, in the absence of an increase in domestic (private) savings and given a decline in aggregate (public and private) savings, additional investment to finance the deficit could come only from abroad..$^{258}$

Sinn also argues that the consequences of this inflow were clearly beneficial to the United States and detrimental to the rest of the world:

The first half of the [1980s] was characterized by enormous capital imports into the United States accompanied by a strong dollar and a high world interest rate level. Most countries suffered from this situation. Europe was driven into the worst recession of the post-war period, and the developing countries were shaken by one debt crisis after another. A number of countries were unable to meet their interest obligations, and a collapse of the world banking system was avoided only by strenuous effort. The United States alone seemed to have benefited: despite the high interest rate it enjoyed a significant consumption and investment boom. ${ }^{259}$

Thus, Sinn would have supported action by the EU to curb such tax competition from the United States by, for example, taxing its residents on their U.S.-source income. But it is unlikely that the United States would have agreed to cooperate in such a move (and thereby to forgo the benefits of its tax reduction). Without U.S. cooperation, it is unlikely that Europe could have succeeded in taxing its individual residents on their U.S. source income. ${ }^{260}$

Moreover, from a normative perspective, the United States could argue that it has no obligation to maintain a larger public sector than

nated tax shelters, broadened the tax base, and reduced rates. The I 986 Act was intended to be revenue neutral so that it would preserve the overall tax cut of I981. See Joel Slemrod, The Economic Impact of the Tax Reform Act of 1986 , in Do TAXES MATTER? THE IMPACT OF THE TAX REFORM ACT OF I986 I, 2-3 (Joel Slemrod ed., I990). Consequently, budget deficits persisted through the I980s. The 1986 Act led many foreign governments to reduce their rates and broaden their base. See John Whalley, Foreign Responses to U.S. Tax Reform, in Do TAXES MATTER?, supra, at 286, 286-87, 288 tbl.9.I.

256 Pub. L. No. 97-34, 95 Stat. I 72.

257 See Hans-Werner Sinn, United States Tax Reform I98I and 1986: Impact on International Capital Markets and Capital Flows, in MUNICH SYMPOSIUM, supra note 28, at 25, 31 .

258 See McLure, Intermational Considerations, supra note 29, at 7 . McLure states, however, that "[r]elatively few seem to have appreciated the full international consequences of these actions." Id.

259 HANS-WERNER SINN, CAPITAL INCOME TAXATION AND RESOURCE ALLOCATION 224-25 (1987).

260 Most of the capital inflow took the form of individual portfolio investment, which, as I argue in section II.A, is difficult to tax unilaterally on a residential basis. 
its citizens desired and that its citizens were entitled to the tax cuts they supported, even if those cuts had negative incidental effects on Europe. The U.S. government's primary obligation is the welfare of the citizens who elect it, not that of Europeans.

However, consider as a counterexample the portfolio interest exemption enacted in 1984 to facilitate financing the same deficit. As Part II describes, this provision targeted foreigners exclusively. ${ }^{261}$ It was not widely discussed in Congress or elsewhere and was passed largely at the behest of the Treasury and U.S. banks. ${ }^{262}$ As a provision aimed solely at foreigners, it had a relatively small impact on the overall size of government; the tax expenditure budget does not even include it. But the results for Latin American countries, which lost $\$ 300$ billion in capital flight as a direct result of the exemption's enactment, were devastating. ${ }^{263}$ In part because of the lack of public exposure that the provision received, the administration apparently did not foresee these results. ${ }^{264}$ If these effects were indeed foreseeable, perhaps the government should have chosen other means to reduce the cost of borrowing (for example, by maintaining the Netherlands Antilles treaty or renegotiating the treaty with Japan).

Therefore, I recommend that proposals to curb tax competition (such as the current EU and OECD proposals) be evaluated based in part on the extent to which they observe the above distinction, as well as on their likely effectiveness in practice. In particular, proposals that would have limited the United States's ability to enact ERTA are unlikely to succeed in practice; proposals that would have prevented the enactment of the portfolio interest exemption are much more likely to prove successful. In Part V, I attempt such an evaluation.

\section{THE COSTS AND BENEFITS OF TAX COMPETITION FROM EACH COUNTRY's PERSPECTIVE}

In Part III, I discussed the arguments from a global perspective for and against tax competition. However, it is not an authoritative "world tax organization" that designs international tax rules, but each country acting separately with its own interests in mind. Thus, in this Part, I analyze the costs and benefits of tax competition from the perspectives of the affected countries, turning first to developed welfare states and then to developing and transition economies. Finally, I analyze how tax competition affects the division of tax revenues

\footnotetext{
261 See supra p. 1579.

262 The banks also succeeded in inserting a provision to deny the benefits of the exemption to foreign banks. See I.R.C. $\$ 88 \mathrm{I}$ (c)(3)(A) (I994).

263 See Mclure, Capital Flight from Latin America, supra note 29, at 343-46.

264 See McLure, International Considerations, supra note 29, at 8-9.
} 
among countries, a division that relates to the concept of inter-nation equity.

\section{A. Developed Countries and the Fiscal Crisis of the Welfare State}

The welfare state, which began over a century ago with Bismarck's social insurance scheme (financed by a comprehensive income tax), ${ }^{265}$ now faces a severe fiscal crisis. The fundamental problem is an aging population - the result of the post-World War II baby boom and an increasing life span, together with a decreasing number of births. The result has been a significant increase in almost every OECD member country's "dependency ratio," defined as the ratio of the young (those under age twenty) and the elderly (those above the retirement age for public pensions) to the working-age population. For example, in Japan the dependency ratio will rise from about $40 \%$ in 1995 to a peak of $60 \%$ in 2045 ; in Germany it will rise from $30 \%$ in I 995 to over $60 \%$ in 2035. Even in the United States, which has relatively high fertility and immigration rates, the dependency ratio will rise from about $20 \%$ in 1995 to $40 \%$ in $2035 .{ }^{266}$ In the OECD generally, the percentage of the population over 60 will rise from $18.2 \%$ in 1990 to $27.0 \%$ in 2020 and will peak at $31.2 \%$ in 2050.267

The fiscal implications of this "old age crisis" are profound. ${ }^{268}$ The OECD has published fiscal scenarios for its members based on their starting positions in 2000, their various demographic changes, and their budgets' susceptibility to the effects of aging under existing arrangements for public pensions and public health spending. ${ }^{269}$ The projections indicate that by 2030 , all of the OECD members studied except Ireland will experience a budget deficit, ranging from $0.5 \%$ of GDP in Belgium to $8.7 \%$ of GDP in Japan. ${ }^{270}$

"Generational accounting" is helpful in analyzing the tax implications of this phenomenon. Generational accounting compares the estimated lifetime net tax rates facing future generations with the rate today's newborns must pay to finance current government programs

265 See, e.g., AlEXANDER HICKS, SOCIAL DEMOCRACY AND WELFARE CAPITALISM I 3 (I999).

266 See Deborah Roseveare, WILli leibfritz, DOUGLas FORE \& ECKHARD WURzel, Ageing Populations, PENSION SySTEMS AND GOVERNMENT BUdGeTS: SIMUlations FoR 20 OECD COUNTRIES 27 fig. I (OECD Econ. Dep't Working Paper No. 168, 1996).

267 See McLure, Keynote Address, supra note 35 , at 3.

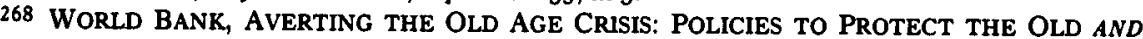
Promote Growth I (I994) [hereinafter AVERTING THE OLD AGE CRISIS]; see also ESTELLE James, Protecting the Old and Promoting Growth: A Defense of AVERTING THE OLD $A G E$ CRISIS 2 (World Bank Policy Research Dep't Working Paper No. 1570, 1996).

269 See ROSEVEARE, LEIBFRITZ, FORE \& WURZEL, supra note 266, at 5-6.

270 See id. at 21 tbl.s. The OECD study projects that the United States will be roughly in the middle, with a deficit of $3.8 \%$ of GDP. See id. For more data on the old age crisis and its fiscal implications, see OECD, MAINTAININg PROSPERITY IN AN AGEING SOCIETY 9-26 (I998); and OECD, NEW DIRECTIONS IN HEALTh CARE POLICY I3-I9 (I995). 
without change.271 Kotlikoff estimates that for future generations in the United States, the net tax rate will be an impossibly high $84 \% . .^{272}$ To equalize lifetime net tax rates of current newborns and future generations from 2006 onward, Kotlikoff estimates, it will be necessary either to increase federal income taxes by $61 \%$, to cut transfer payments by $43 \%$, ol: to reduce federal purchases by (an impossible) I09\%. ${ }^{273}$ The picture is similar for other countries: the generational imbalance for males - the increase in net tax payments for future generations required to finance future benefits at current rates - ranges from $27 \%$ in Germany to $446 \%$ in Italy. ${ }^{274}$

An OECD study concludes: "Where major fiscal pressures have been identified .... some policy action will be needed to redress imbalances. Without such action, government dissaving could also lead to significant reductions in national savings in some countries . . ."275 The OECD study identifies three policy options: to increase the workforce through immigration; to increase taxes or cut other expenditures; or to cut health and pension programs. ${ }^{276}$ The first option is unrealistic given the number of immigrants required. The second option is likewise untenable because to cut other expenditures by the necessary amount would require, for example, that the United States eliminate all defense spending and that Japan cut double its projected expenditures on general public services and defense. As for raising taxes, "[g]iven concerns about existing overall tax burdens, the option of raising taxes is not considered further."277 The third option, cutting social programs, is the only viable alternative remaining.

271 See The Erosion of the American Dream: Hearing Before the House Comm. on the Budget, I04th Cong. 28-29 (I 996) (statement of Laurence J. Kotlikoff, professor of economics, Boston University). Net tax payments are taxes paid less transfers received; lifetime net tax rates are the projected net tax payments divided by the present discounted value of projected earnings. See id. at 29.

272 See id. at $30-31$.

273 See id. at 32-33 \& chart 2. All of these may seem politically impossible, but if the United States were to introduce a VAT, revenues would likely exceed $60 \%$ of current federal revenues from the income tax. (In other OECD members, VAT revenues almost equal income tax revenues.) In general, it is unclear why a debate on the future of social insurance in the United States has to assume revenue neutrality, a point illustrated in GRAETZ \& MASHAW, supra note 199 , at 177.

274 See WILLJ. LeIBFRTZ, DEBORAH ROSEVEARE, DOUGLAS FORE \& ECKHARD WURZEL, Ageing Populations, Pension Systems and Government Budgets: HoW DO They AFFECT SAVING? 40 tbl.i I (OECD Econ. Dep't Working Paper No. I56, I 995).

275 Id. at 17 . The last point refers to the possibility that the government may finance its budget deficit through borrowing. This practice is generally considered to have adverse effects on the economy because it crowds out private investment options. See, e.g., Theodore P. Seto, Drafting a Federal Balanced Budget Amendment That Does What It Is Supposed to Do (and No More), I06 YALE L.J. I 449, 1463 (1997); Herbert Stein, The Significance of Budget Deficits, in A NATION IN DEBT: ECONOMISTS DEBATE THE FEDERAL BUDGET DEFICIT 235, 238-39 (Richard H. Fink \& Jack C. High eds., I987).

276 See LEIBFrITZ, ROSEVEARE, FORE \& WURZEL, supra note 274, at 18-23.

277 Id. at 21 . 
The OECD study's conclusion regarding taxes seems too broad. The key questions are what types of taxes are involved and in which countries. In the United States, for example, because overall taxation amounts only to about $30 \%$ of GDP, there appears theoretically to be considerable opportunity for raising additional revenues (for example, by means of a VAT) before reaching European levels of public expenditure (about $50 \%$ of GDP). In Europe, the possibility of raising taxes is much more limited. VAT rates in many European countries now exceed $20 \%, 278$ which is about as high as a consumption tax can go before the incentive to consume elsewhere becomes too significant and enforcement costs swallow the additional revenues. Payroll taxes currently fund most social insurance, but given the high level of unemployment in Europe, it seems counterproductive to raise payroll tax rates even further. ${ }^{279}$ In addition, high payroll tax rates may create inefficient incentives for employers to hire part-time or foreign workers whose wages are not subject to the same rates. ${ }^{280}$

Still remaining for consideration is the option of raising more revenue through the income tax. Raising income taxes risks exacerbating current distortions - which inhere in Europe's current high rates of income tax - in the choices of whether to work and whether to save or consume. However, as Part $\Pi$ explains, income from cross-border investments is currently taxed at effective rates much lower than the generally applicable ones. Therefore, to tax such income at rates that approximate the rates on domestic investment would both advance world efficiency and equity and raise more revenue to help address the fiscal crisis described above. 281

This rationale may explain the EU's and OECD's interest in curbing "harmful tax competition" even though there may be insufficient evidence of actual erosion of the tax base. The potential for erosion certainly exists, and OECD governments are acutely aware that, at least until 2050 or so, they will need every penny they can collect in taxes to sustain their promises to the baby boom generation. Because of the demographically predictable need for additional revenues and the potential for tax-base erosion resulting from globalization, it is not

\footnotetext{
278 See OECD, CONSUMPTION TAX TRENDS I3 tbl.1.5 (2d ed. I997) (showing rates at $20 \%$ or above in ro OECD member countries).

279 See OECD, IMPLEMENTING THE OECD JOBS STRATEGY 63-64 (I997); OECD, MAKING WORK PAY: TAXATION, BENEFITS, EMPLOYMENT AND UNEMPLOYMENT 65 (1997); OECD, THE OECD JOBS STUDY: TAXATION, EMPLOYMENT AND UNEMPLOYMENT 68 (1995).

280 See Jack M. Mintz, Is National Tax Policy Viable in the Face of Global Competition?, I999 WORLDWIDE TAX DAILY 128-20, II $3 \mathrm{r}$, available in WL 1999 WTD $128-20$.

281 However, as discussed above, it is unclear how much revenue a government can raise in this way, and it is unlikely that sufficient revenues would be available even in the ideal scenario. The numbers may be more significant for developing countries.
} 
surprising that the developed countries are taking actions to shore up the income tax base even before any significant erosion has occurred.

This analysis will appear to many readers to beg the question: why should the welfare state not be drastically reduced? Political realities may coerce governments to maintain existing programs, but from a normative perspective, it is less clear that governments should dole out billions in pensions and health care expenditures for the elderly, especially when the private sector can assume some of the burden.

There are two answers to this question, both of which ultimately depend on normative value judgments that not everyone may share. The first answer is given by Dani Rodrik: failure to maintain existing social insurance programs invites a political backlash against globalization and a return to 1920 -style protectionism and isolationism. ${ }^{282}$ Rodrik points out an empirical relationship between economies becoming more open to investment and increased spending on social insurance programs. Calculating the relationship between openness and the size of government yields an "unmistakable positive association" that is not exclusive to OECD countries. ${ }^{283}$ This relationship is attributable to social insurance's role in minimizing exposure to increased external risk. Opening the economy to competition from abroad increases risk to both income and consumption due to increased specialization and the difficulty of diversifying human capital. 284 Theoretically, decreased exposure to domestic risks (that is, the ability to invest abroad) could offset such increased risk, but Rodrik shows empirically that for I05 countries, increased openness results in a net absolute increase in risk to both income and consumption. ${ }^{285}$ The risk appears in terms of both income insecurity (for example, loss of employment) and income volatility (extreme fluctuations as a result of more frequent job shifts). In terms of distributional effects, the increased risk probably falls on the less mobile factors in society (primarily unskilled and semiskilled labor), as increasing income disparities suggest. ${ }^{286}$

Social insurance programs can reduce such risks. The most direct mechanism of risk reduction is unemployment insurance, which can hedge against increased risk to income levels as well as against the job volatility that results from globalization. Pensions and health care

282 See RODRIK, GLOBALIZATION, supra note 189 , at $49-69$. For a critique of Rodrik's approach, see Paul B. Stephan, Book Review, 18 NW. J. INT'L L. \& BUS. 246 (I997).

283 RODRIK, GLOBALIZATION, supra note 189 , at 52.

284 See id. at 55.

285 See id. at 57.

286 See Peter Gottschalk \& Mary Joyce, The Impact of Technological Change, Deindustrialization, and Internationalization of Trade on Earnings Inequality: An International Perspective, in POVERTY, INEQUALITY, AND The FUTURE OF SOCIAL POLICY 197, 1.97-228 (Katherine McFate, Roger Lawson \& William Julius Wilson eds., 1995) (measuring income inequality trends in the United States relative to those in other OECD countries). 
coverage can also play a major role in reducing lifetime uncertainty over income, which increases individuals' willingness to tolerate exposure to external risks. ${ }^{287}$

If governments cut social insurance programs as a result of the fiscal crisis described above, these buffers against the risks inherent in globalization disappear. Such cuts can give rise to massive social resistance - for example, the French strikes of 1996 , which were sparked by the need to cut social programs to meet the Maastricht budgetary guidelines for monetary union. It is no accident that, as Europe moved closer to economic integration in the I990s, voters in almost all European countries elected left-of-center governments on platforms of protecting social insurance programs. ${ }^{288}$ At the same time, extreme right-wing parties committed explicitly to resisting globalization saw increases in their support. ${ }^{289}$ As Rodrik points out, the danger is that the erosion of social insurance programs could lead to a retreat from the commitment to openness that characterized the I 980 s and early I990s. ${ }^{290}$ Assuming - as most critics of the welfare state do - that globalization is itself a positive phenomenon, and remembering the previous retreat from globalization, which led to worldwide depression and world war, such an outcome would be unfortunate, to say the least.

The second argument in favor of social insurance programs is purely normative. To make it, one must distinguish between social insurance and social assistance, both of which are parts of the modern welfare state. ${ }^{291}$ Social assistance is government aid designed to ensure every citizen a basic level of resources for living. By contrast, social insurance is designed, more minimally, to ensure that citizens who are unable to work because of (young or old) age, disability, health, or temporary unemployment can replace the income they had while working. ${ }^{292}$ Social insurance, unlike social assistance, is related to employment status and typically to contributions paid by the worker.

\footnotetext{
287 See RODRIK, GLOBALIZATION, supra note 189 , at 58.

288 See Unsocialist Realism, ECONOMIST, Oct. 3, I998, at 66; Martin Walker, Europe's Third Way Labs: Tony Blair's Formula for Reform Is Contagious on the Continent, NEW DEMOCRAT, May/June I 999, at 8.

289 See Tony Judt, The Social Question Redivivus, FOREIGN AFF., Sept./Oct. I 997, at 95, 96

290 See RODRIK, GLOBALIZATION, supra note I89, at 9; see also DANI RODRIK, TRADE, SOCIAL INSURANCE, AND THE LIMITS TO GLOBALIZATION 4 (National Bureau of Econ. Research Working Paper No. 5905, 1997).

291 For the definitions of these terms, see JOHN DITCH, JONATHAN BRADSHAW, JOCHEN

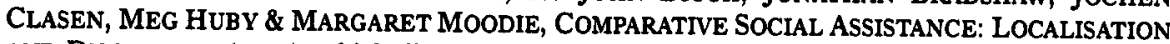
AND DISCRETION (I 997), which discusses social assistance systems in Germany, the Netherlands, Sweden, and Switzerland; and I TONY EARDLEY, JONATHAN BRADSHAw, JOHN DITCH, IAN Gough \& PETER WhITEFORD, SOCIAL ASSISTANCE IN OECD CouNTRIES 15 (I996) [hereinafter SOCLAL ASSISTANCE].

292 See GRAETZ \& MASHAW, supra note I99, at 27-28.
} 
This Article focuses on social insurance rather than social assistance for two reasons. First, social insurance is more clearly linked to the pressures resulting from globalization, because globalization may result in increased income insecurity and volatility for those who have or had jobs. Second, social insurance enjoys far broader acceptance among OECD members than does social assistance: all OECD member countries have some form of social insurance programs, which are very popular, whereas only some OECD members have social assistance programs, which enjoy much less popular support. ${ }^{293}$

Social insurance is popular precisely because in a market economy people may lose their source of income due to factors beyond their control. No one can escape being too young or too old to earn a living, nor is it possible to forestall illness, disability, or unemployment caused by such uncontrollable factors. Ex ante, everyone faces a similar likelihood of suffering from such income disruptions: "there but for the grace of God go I." Thus, it is not surprising that social insurance programs designed to prevent such risks from threatening a reasonable standard of living are so widespread. As Michael Graetz and Jerry Mashaw state: "[S]ocial insurance thus represents one of the greatest triumphs of twentieth-century domestic public policy .... [S]ocial insurance is a crucial underpinning of a vibrant market economy."294. It seems unrealistic, given the data about inequality, ${ }^{295}$ to expect most people to supplement even predictable declines in income purely from their own savings.

Moreover, the private market may be an inadequate substitute for many social insurance programs, for a variety of reasons. First, the risk can be too uncertain for private insurance companies to predict actuarially. Second, risks can co-vary in ways that threaten all policyholders at once, like the demographic changes described above. If the risk is not adequately diversifiable, private insurance may become impossible to obtain. Third, adverse selection may occur if the potential insured know the risks much better than the insurers, resulting in overrepresentation of high risks in the insurance pool and possibly leading to premiums so high that they price all low and moderate risks out of the market. Finally, there may be cases of extreme moral hazard when the insured changes her behavior to increase the risk. ${ }^{296}$

293 Support for social assistance is particularly attenuated in the United States. See I SOCLAL ASSISTANCE, supra note 29I, at I2. For a measure of the programs' support in the United States, see Virginia P. Reno \& Robert B. Friedland, Strong Support but Low Confidence: What Explains the Contradiction?, in SOCIAL SECURITY IN THE 2 IST CENTURY I78, 178-94 (Eric R. Kingson \& James H. Schulz eds., 1997).

294 GRAETZ \& MASHAW, supra note 199 , at $4,8$.

295 See sources cited supra note 286.

296 See GRAETZ \& MASHAW, supra note 199 , at 296-99; Lawrence H. Thompson \& Melinda M.

Upp, The Social Insurance Approach and Social Security, in SOCIAL SECURITY IN THE 2 IST 
Government insurance can alleviate these problems, at least theoretically, with a combination of taxation and regulation. The uncertainty problem can be overcome by paying compensation when the risk materializes and levying taxes at that point to pay the costs. Covariance of risk is addressable because governments do not go out of business; they can borrow and then tax to meet their debts. Adverse selection disappears with a government mandate to insure everyone, and effective regulation (for example, requiring the unemployed to seek work) can reduce moral hazard. ${ }^{297}$

As argued above, globalization results in increased job insecurity, income volatility, and income disparity, which enhance rather than reduce the need for government-provided social insurance. The risks posed by globalization are inherently uncertain and covariant, falling on many people at once in an unpredictable pattern. In addition, both adverse selection and moral hazard problems are inherent in those risks. Adverse selection occurs because insurance companies are typically less able to assess an employee's chances of being displaced by global competition than is the employee herself (or her employer, who in a typical private market provides the insurance). And moral hazard is the major problem in providing unemployment insurance, as the employee is generally able to take many steps to mitigate or exacerbate the risk.

Unemployment insurance is not the only type of social insurance affected by globalization. The largest social insurance expenditures are for pensions and health care costs. Although these costs depend, for the most part, on demographic trends that are unrelated to globalization, the risk of inadequate income during old age or illness also depends on the availability of private savings. If employees have to save primarily to cover periods of temporary unemployment, they may not have enough to compensate for loss of income resulting from disability or old age. Particularly in a system like that in the United States, in which both pensions and health insurance are tied to permanent, fulltime employment, the decline of full-time, unionized jobs with attached benefits is directly linked to globalization and the increasing need for government-mandated social insurance. ${ }^{298}$

CENTURY, supra note 293, at 3, 5. For discussions from a European perspective of the appropriate public/private mix in providing social insurance, see OECD, PRIVATE PENSIONS AND PUBLIC POLICY (1992); and Martin Rein \& Eskil Wadensjö, The Emerging Role of Enterprise in Social Policy, in ENTERPRISE AND THE WELfARE STATE I, I-33 (Martin Rein \& Eskil Wadensjö eds., 1997).

297 See GRAETz \& MASHAW, supra note I99, at 297; OECD, BENEFIT SYSTEMS AND WORK INCENTIVES 49-50 (I998).

298 For a strong critique of the U.S. social insurance system, see GRAETZ \& MASHAW, supra note 199, at 26-46. See also Michael J. Graetz, The Troubled Marriage of Retirement Security and Tax Policies, I35 U. PA. L. REV. 85 I (I987) (arguing that current policies provide inadequate retire- 
Faced with this demographic challenge, developed countries must prevent the erosion of their individual and corporate income tax bases, which still provide the largest source of revenue in almost all OECD member countries. At least in Europe, increasing other taxes (specifically, the VAT and payroll tax) to cover any shortfall in income tax revenues is not a viable alternative for the reasons discussed above. ${ }^{299}$ Moreover, as globalization increases income disparity, using the progressive income tax to fund social insurance programs that reduce such disparities seems particularly appropriate.

Given the extent of the fiscal crisis described above, however, no amount of change in income taxes is likely to produce sufficient revenue to preserve existing social insurance programs unchanged in all OECD member states. In particular, the imposition of effective income taxation on cross-border transactions, as this Article advocates, would not suffice to solve fiscal deficits; some existing programs must be changed, though in ways that are consistent with their normative underpinnings, such as increased use of means-testing. ${ }^{300}$ But there is a strong normative case in favor of ensuring that globalization leaves sufficient income tax revenues to fund whatever social insurance programs can and should be retained.

\section{B. Developing Countries and Tax Incentives}

The analysis above suggests that developed countries are interested in protecting their income tax base from tax competition with developing countries, and that they have adequate normative grounds for wishing to do so. But what about developing countries? Are they not interested in engaging in tax competition to attract foreign investors, and should they not resist any attempt by developed countries to prevent them from so doing?

Several arguments need to be addressed here. First, one might contend that developing countries need tax revenues less than developed

ment income security for low- and moderate-income employees); Jeffrey S. Lehman, To Conceptualize, To Criticize, To Defend, To Improve: Understanding America's Welfare State, IOI YALE L.J. 685 (I99I) (reviewing THEODORE R. MARMOR, JeRRY L. MASHaW \& PHILIP L. HaRVey, AMERICA'S MISUNDERSTOOD WELFARE STATE (I990)). For a discussion of the vulnerable position of retirees in the United States and Canada, see OECD, THE TRANSITION FROM WORK TO RETIREMENT I 19-25 (1995).

299 Arguably, even in the United States, social insurance programs can only be preserved by using general tax revenues, which come primarily from the income tar. See GRAETZ \& MASHAW, supra note I99, at 285-87. However, as Graetz and Mashaw recognize, the U.S. social insurance system is so grossly inadequate that to expand it to adequate levels would require adopting a VAT, as every other OECD member country has done.

300 European countries are largely moving in this direction. See x SOCIAL AsSiSTANCE, supra note 29r, at 23. But see Eric R. Kingson \& James H. Schulz, Should Social Security Be MeansTested?, in SOCLAL SECURITY IN THE 2 IST CENTURY, supra note 293, at 41 (arguing against means-testing on political grounds). 
countries because they are not welfare states and are therefore less affected by the fiscal crisis described above. Second, one can make an economic case that developing countries should refrain from taxing any foreign investment. Finally, one might argue that tax competition is the only way for developing countries to attract crucially needed foreign investors, even if doing so imposes a cost on developed countries.

I. Do Developing Countries Need Tax Revenues? - A common misperception is that the fiscal crisis described above is a problem unique to OECD members. In fact, as fertility rates go down and health care improves, dependency ratios are expected to increase in other geographic areas as well. ${ }^{301}$ Outside the OECD and the transition economies, the dependency ratio was less than $10 \%$ in the 1990 s but is projected to rise to just below $30 \%$ by $2100 .{ }^{302}$ Nor is it accurate to say that social insurance programs are unique to developed countries. Spending on pensions in several Central and Eastern European countries (transition economies) has already reached proportions of GDP comparable to those in the OECD member countries. ${ }^{303}$ Outside the transition economies, direct spending on social insurance is much lower, but other forms of government spending effectively fill a social insurance role. In Latin America, for instance, a number of countries have implemented extensive government employment and procurement programs. ${ }^{304}$

Furthermore, the normative case for social insurance applies to developing countries with even greater force because widespread poverty in these countries makes the consequences of unemployment much more severe. ${ }^{305}$ But the need for tax revenues in developing countries extends far beyond social insurance. In some developing countries, tax revenues are needed to ensure the very survival of organized government, as the recent Russian fiscal crisis demonstrated.306 In other, more stable developing countries, tax revenues are needed primarily to

\footnotetext{
301 See, e.g., AVERTING THE OLD AGE CRISIS, supra note 268 , at 303 tbl.3.I.

302 See McLure, Keynote Address, supra note 35, at 3. This statistic excludes Central and Eastern Europe, where the ratios are as high as in Western Europe.

303 See AVERTING THE OLD AgE CRISIS, supra note 268, at I 42 box 4.7.

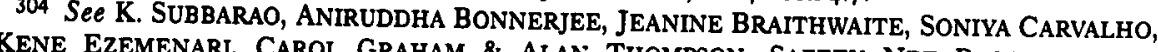
POVER POVERTY REDUCTION: LESSONS FROM CROSS-COUNTRY EXPERIENCE 138-44 (I 997).

305 The UN has estimated that the world could ensure access to basic social services for all its people for a mere $\$ 30$ to $\$ 40$ billion a year. See HUMAN DEVELOPMENT REPORT, supra note I03, at 112 box 6.4 ( 1997 ).

306 See, e.g., Andrew Higgins \& Mark Whitehouse, Russia Crisis Deepens as Duma Rejects Premier, WALl ST. J., Sept. I, 1998, at Aro; Meltdown in Russia, ECONOMIST, Aug. 29, I998, at 47.
} 
provide for adequate education (investment in human capital), which many regard as the key to promoting development. ${ }^{307}$

One could also argue that because the governments of many developing countries are inefficient, corrupt, and/or authoritarian, they deserve no additional tax revenues. Although this description undoubtedly fits many third-world countries, it is far less accurate today than it was twenty years ago. Democracy is more prevalent now than in I $980,{ }^{308}$ and corruption is declining (in part because of recent OECD efforts to combat it and in part because of constraints imposed by globalization itself). ${ }^{309}$ Moreover, arguments from desert seem more relevant to the amount of direct aid given to developing countries than to the design of these countries' tax rules. While direct aid can be targeted at those countries whose governments seem able to use it best, it is doubtful that tax rules can be targeted in this way. ${ }^{310}$ It seems inappropriate to refrain from designing general tax rules that would enable all developing countries to raise needed revenues merely because in some cases those revenues might be used for undesirable ends, such as lining an official's pockets or enabling a dictator to wage war more effectively. In fact, insofar as the tax rules are directed to foreign investment, those investments are more likely over time to flow to countries with less corruption and more democratic governments. ${ }^{311}$

2. Should Developing Countries Tax Foreign Investors? - Economists make a more powerful argument in favor of allowing developing countries to engage in tax competition when they contend that small, open economies should generally refrain from taxing foreign investors. $^{312}$ The argument goes as follows: If an economy is small, it must accept worldwide prices (including interest rates) as given. If it is open, foreign investors can choose to invest there or elsewhere. Because foreign investors will not accept an after-tax yield that is lower than the yield available elsewhere (which, by definition, the small economy cannot affect), they cannot be made to bear the burden of

307 See, e.g., OECD, HUMAN CAPITAL INVESTMENT: AN INTERNATIONAL COMPARISON 8 (1998); Amartya Sen, Development Thinking at the Beginning of the XXI Century, in ECONOMIC AND SOCIAL DEVELOPMENT INTO THE XXI CENTURY 531, 540-42 (Louis Emmerij ed., I 997).

308 See RODRIK, NEW GLOBAL ECONOMY, supra note 242, at 82-I00, I05-10.

309 See SUSAN ROSE-ACKERMAN, CORRUPTION AND GOVERNMENT: CAUSES, ConsEQUENCES, AND REFORM I85-87, I89 (1999).

310 U.S. attempts to tailor tax rules to the practices of certain developing countries (such as their support for terrorism) have not had encouraging results, at least if their purpose was to deter the targeted behavior. See JAMES R. HINES, JR., TAXED AvoIDANCE: AMERICAN PARTICIPATION IN UNSANCTIONED INTERNATIONAL BOYCOTTS (National Bureau of Econ. Research Working Paper No. 6I16, I997); Canute R. Miller, Third World Views of the Ends and Means of United States Tax Policy, in UNITED STATES TAXATION AND DEVEloping CoUNTRIES 83, 91 -102 (Robert Hellawell ed., I980).

311 See RODRIK, NEW GLOBAL ECONOMY, supra note 308, at 96-99.

312 See, e.g., Razin \& Sadka, International Tax Competition, supra note 133. 
any tax imposed by the capital-importing country. The tax will then necessarily be shifted to less mobile factors in the host country, such as labor and/or land. Because taxing those factors directly is more efficient, this view holds that a small open economy should only tax domestic labor, land, and (if it can) domestic capital invested either domestically or overseas, but not foreign capital.

This argument seems quite valid as applied to portfolio investment, which can earn the worldwide rate of interest free of tax in many locations around the world. The only effective way to tax such portfolio investment is on a residence basis, although as an administrative matter, coordinated, source-based backup withholding may be needed to enforce the tax. As applied to FDI, however, the argument is less valid, for two reasons.

First, the argument presupposes that a foreign tax credit is not available for the tax. If a foreign tax credit is available in the investor's home country, the investor is unaffected by the host-country tax (since she would have to pay the tax to either the home or host jurisdiction). Thus, if the host country refrains from taxation, it is merely giving away revenue to the home country. This situation is relatively rare for portfolio investment because (as argued above) home countries are rarely able to tax such investment, making the credit irrelevant. ${ }^{313}$ However, in the case of direct investment, the credit is generally available, and therefore host countries should not refrain from taxing the investor. ${ }^{314}$

Second, the argument assumes that the host country is small and that the investing MNE can earn similar returns elsewhere. This premise, in turn, assumes a competitive market situation. However, an extensive body of literature on MNEs suggests that they typically exist in order to earn economic rents - super-normal returns that result from an imperfect market. ${ }^{315}$ In a perfectly competitive market, it

\footnotetext{
313 Host-country taxation does make sense in the case of banks. For example, in the U.S.Mexico tax treaty, the withholding tax rate on interest $(4.9 \%)$ is precisely geared to the amount available for credit to U.S. banks (because a $5 \%$ or greater tax would be in a separate basket). See Convention for the Avoidance of Double Taxation and the Prevention of Fiscal Evasion with Respect to Taxes on Income, Sep. 18, I992, U.S.-Mex., art. I I, S. TREATY DoC. No. 103-7 (I 993).

314 See TIMo VIHERKENTTA, TAX INCENTIVES IN DEVELOPING CoUNTRIES AND INTERNATIONAL TAXATION 7 I-I39 (I99I). The credit's wide availability raises a question that has puzzled economists: why do home countries grant the credit? See Bond \& Samuelson, supra note 148 , at rog9. The answer lies in the history of the credit, which was enacted under heavy pressure by MNEs wishing to avoid double taxation. See Michael J. Graet2 \& Michael M. O'Hear, The "Original Intent" of U.S. International Taxation, 46 DUKE L.J. 102 I, 1044-5 I (1997). In any case, it would be strange to argue in favor of abandoning an already existing credit system that advances world welfare for a system that would at best enhance only national welfare.

315 See Jean-François Hennart, The Transaction Cost Theory of the Multinational Enterprise, in The Nature OF THE Transnational FIRM 8I, 8I-85 (Christos N. Pitelis \& Roger Sugden eds., I99I).
} 
generally makes more sense for MNEs to operate through independent distributors, given the transaction costs of operating directly in foreign markets. It thus may make sense for MNEs to engage in FDI only in imperfectly competitive markets - where rent-seeking is possible.

If an investor earns rents in a country, that country is not only not perfectly competitive, but also not "small" in the economic sense that is, the investor has a reason to be there and not elsewhere. Therefore, any tax imposed on such rents (as long as it is below 100\%) will not necessarily drive the investor to leave, even if the investor is unable to shift the burden of the tax to labor or landowners. However, the host country will not be able to tax the rent if the MNE can credibly threaten to go elsewhere to earn the same rent. ${ }^{316}$ This situation, probably the most common, ${ }^{317}$ would require coordinated action to enable all host countries to tax the rent earned within their own borders.

3. Do Developing Countries Need to Offer Tax Incentives to Attract Foreign Investment? - The standard advice given by international institutions like the World Bank and the IMF to developing countries is to refrain from offering tax incentives to foreign investors. For example, the IMF's Tax Policy Handbook states that "[t]he IMF maintains a widely held view that tax incentives of all sorts have proved to be largely ineffective, while causing serious distortions and inequities in corporate taxation." 318 In the I980s, an IMF mission to Indonesia successfully advocated the abolition of all tax incentives for foreigners. Similarly, a World Bank study of Central and Eastern Europe recommended eliminating all tax incentives and instead levying a low, general corporate tax rate. ${ }^{319}$ In attracting foreign investors, it is argued, a country's overall business climate (which includes such factors as a stable government, a well-educated workforce, and good infrastructure) is much more important than specific tax incentives. ${ }^{320}$

\footnotetext{
316 For example, the rent could be the result of possessing a unique intangible (an "ownershipspecific" advantage, to use the terminology developed by Dunning). See JOHN H. DuNNING, EXPLAINING INTERNATIONAL PRODUCTION 3 (1988). Such an intangible could be a patent or another form of know-how, such as a manufacturing technique that reduces costs drastically.

317 See Hennart, supra note 315 , at 96-98.

318 Janet Stotsky, Summary of IMF Tax Policy Advice, in TAX PoliCy HaNDBOoK, supra note 203 , at 279,282 .

319 See JaCk M. MinTz \& Thomas Tsiopoulos, CoRporate InCOME TAXation AND FOREIGN DIRECT INVESTMENT IN CENTRAL AND EASTERN EUROPE Io (I992); see also OECD, TAXATION AND FOREIGN DIRECT INVESTMENT: THE EXPERIENCE OF THE ECONOMIES IN TRANSITION 30 (I995) ("In most econometric studies on the question, the foregone tax revenue [from tax incentives] has exceeded the increase in the desired investment.").

320 See OECD, Promoting FOREIGN DIRECT INVESTMENT IN DEVELOPING Countries 53 (I993) ("Do not build a programme around tax holidays."); see also Jack M. Mint2, Corporate Tax Holidays and Investment, 4 WORLD BANK ECON. REV. 8 I (I990) (arguing that tax holidays are often ineffective).
} 
This view is also widely shared by academics, who agree that there is little evidence that tax incentives attract foreign investment effectively. For example, Peter Enrich argues in the intranational context:

[F]or as long as [U.S.] states have been racing to outdo each other in the tax breaks they offer, economists and other researchers have been searching for evidence of the influence of states' tax policies on the vitality of their economies. The conclusion from these efforts has been, at best, inconclusive.

All the evidence points to a single conclusion: state tax incentives are a thoroughly unproven tool for promoting economic development. ${ }^{321}$

If one accepts this conclusion, then it is relatively easy to agree with Enrich that constraining countries' ability to engage in tax competition does them no harm. But even in the intranational context, more recent studies based on improved methodology have tended to conclude that taxes do play a more important role in business location decisions than Enrich suggests.322 In the international context, where tax rates are much higher, the impact of taxation is even more decisive. As Hines and others have shown, taxes play a crucial role in determining investment location, at least when international sites are otherwise equivalent. ${ }^{323}$

Moreover, it is hard to dispute that in some cases tax incentives have played an important role in improving the general welfare of a nation's citizens. The most frequently cited case is Ireland, which was severely economically depressed in the early I 980 s but now has the fastest-growing GDP in Europe, with income per capita exceeding that of the United Kingdom This growth was the result of massive foreign investment, attracted by such factors as an educated, English-speaking workforce and an elaborate system of targeted tax holidays. ${ }^{324}$

How, then, can one argue that developing countries should not grant tax holidays to foreign investors even if they generally need the revenues and if doing so is the only way to attract mobile busi-

321 Peter D. Enrich, Saving the States from Themselves: Commerce Clause Constraints on State Tax Incentives for Business, I I O HARV. L. REV. 377, 389-92 (I 996) (footnotes omitted).

322 See, e.g., JOHN D. DONAHUE, DISUNITED STATES 92-119, I7 1-82 (1997) (reaching conclusions opposite to Enrich's but supporting the same policy objectives).

323 See Eric Bond, Tax Holidays and Industry Behavior, 63 REV. ECON. \& STAT. 88 (198I); Michael J. Boskin \& William G. Gale, New Results on the Effects of Tax Policy on the International Location of Investment, in THE EFFECTS OF TAXATION ON CAPITAL ACCUMULATION 2OI (Martin Feldstein ed., I 987 ); Hines, supra note 90.

324 See OECD, OECD ECONOMIC SURVEYS I998-I999: IRELAND 52-54 (I 999); John Murray Brown, Ireland: Eve of an Emerald Era, FIN. TIMES (London), Sept. 22, I998, at Survey I; Rob Norton, The Luck of the Irish, FORTUNE, Oct. 25, I999, at I 94. 
nesses?325 A recent case study focuses on Intel's decision to invest $\$ 300$ million in Costa Rica. ${ }^{326}$ Intel was attracted to Costa Rica primarily by non-tax factors, such as political stability, a general commitment to economic openness, and an excellent educational system; Costa Rica granted it no specific tax breaks or other subsidies.327 But Intel clearly would not have made the investment without Costa Rica's general regime of tax holidays for foreign investors, given the availability of such holidays in Costa Rica's competitors (principally Mexico).328 Several studies have reached similar conclusions on a broader scale. For example, a ground-breaking study by Stephen Guisinger and his colleagues concludes that tax incentives are crucial in attracting foreign investment because countries that do not have them cannot compete with countries that do..$^{329}$ Guisinger defines competitiveness by asking, "[W]ould a foreign investment project have located in a particular country if that country had eliminated its [tax] incentives and disincentives while other countries maintained [tax] incentive policies at existing levels?"330 Using that definition, Guisinger finds that tax incentives are essential to attracting foreign investment.

Guisinger and his colleagues critically assume, however, that developing countries have "no opportunity for cooperative agreements limiting incentive policies." 331 The solutions to the international tax competition problem discussed below presuppose precisely such a multilateral mechanism. Thus, one can argue that given the need for foreign investment tax revenues, developing countries would in general refrain from granting tax incentives if they could be assured of remaining competitive. When they do grant tax incentives, it is precisely because of competition from other developing countries. For example, in 1996 , Israel gave Intel $\$ 600$ million in tax incentives to avert the threatened relocation of its investment to Ireland, ${ }^{332}$ and Indonesia recently reintroduced its foreign investment tax incentives under pres-

325 However, investment need not necessarily come from overseas sources. See Dani Rodrik, The Global Fix, NEW REPUBLIC, Nov. 2, 1998, at 17, 17-19. In some situations, it may be better to promote domestic investment even if FDI is more glamorous. See Bernard Avishai, Israel's Future: Brainpower, High Tech - and Peace, HARV. BuS. REV., Nov.-Dec. r99I, at 50, 5 I; Debra K. Rubin with Neal Sandler, Rebuilding a Nation, ENGINEERNG NEwS-REC., Apr. 27, 1998, at 30, 30-39.

326 See Deborah SPaR, ATtracting High Technology INVESTMENT: INTEl's Costa RICAN PLANT (1998).

327 See id. at 8-10.

328 See id. at 10-I I.

329 STEPHEN E. GuISINGER \& ASSOCS., INVESTMENT INCENTIVES AND PERFORMANCE REQUIREMENTS 37-39 (I985).

330 Id. at 39 .

331 Id.

332 See Robert Lenzner, Investing, Not Giving, Forbes, Dec. 18, 1995, at 106. 
sure to increase investment after the Asian crisis of 1997 and 1998 and to compete with incentives offered by Malaysia and Singapore. ${ }^{333}$

Thus, restricting developing countries' ability to compete for foreign investment by offering tax incentives does not truly restrict the countries' autonomy or run counter to their interests. ${ }^{334}$ Whenever competition from other countries drives a developing country to provide tax incentives, eliminating the competition does not hurt the developing country and may aid its revenue-raising efforts, assuming it can attract investment by other means. Whenever tax incentives are not offered for fear of competition, however, the developing country remains free to lower its generally applicable tax rates.

The Irish case illustrates this distinction. Ireland was able to benefit from the tax incentives it offered foreign investors precisely because it was the only EU member to offer them. That is, Ireland had no real competition given the reality of European tariff barriers and the other EU members' high tax rates. ${ }^{335}$ But Ireland could have achieved the same result by maintaining a lower general tax rate, which it recently implemented as its preferential regime came under heavy EU fire. ${ }^{336}$ In a typical tax competition scenario, however, one developing country is competing directly against another's preferential regime. Because both countries need the revenue, lowering the general tax rate is typically not an option for either. Competition limited to foreign investment is feasible, but it still hurts both countries by costing them revenues, especially if the incentives cancel each other out. ${ }^{337}$ In this case, it would be in both countries' interest to see competition eliminated if a cooperative solution could be found.

In summary, from the perspective of a typical developing country, the revenue loss from granting targeted tax holidays appears unlikely to be adequately offset by the benefits flowing from the resulting investment, because such a country competes for investment not against every other country in the world, but against a limited subset of countries with characteristics similar to its own. When an MNE decides to AI 7.

333 See, e.g., World Watch: Indonesia Seeks to Spur Investment, WaLl ST. J., Jan. 27, 1999, at

334 For a similar conclusion in the context of U.S. states, see DONAHUE, supra note 322 , at $115-$ I9; and Enrich, supra note 321 , at 467.

335 See Gimme Shelter, ECONOMIST, Jan. 29, 2000, at Survey 15, 17.

336 See id. at 16.

337 The additional revenues generated by taxing employees or suppliers of the foreign investor might conceivably more than make up for the revenue lost in granting the preferential ragime. However, if the investment would have been made even without tax incentives, then those revenues could have been generated in addition to direct FDI taxes. In general, there is no evidence that direct investment is motivated solely or even primarily by tax reasons; rather, taxes are crucial in investment decisions only to the extent that they are a factor in deciding among locations that enjoy other similar advantages. See GuISINGER \& ASSOCS., supra note 329, at 39-4I; Hines, Tax Policy, supra note 56, at 405-06. 
look for an investment location, it engages in a process of analysis reminiscent of Fernand Braudel's three levels of historical change. ${ }^{338}$ It first eliminates countries that are unsuitable because of long-term factors, such as geography and climate, and then eliminates countries that are unsuitable because of shorter-term factors under only limited government control, such as labor costs, education levels, or political instability. Finally, the MNE conducts an auction among the remaining countries that focuses on the factors under direct government control, such as tax holidays and other forms of subsidy. In this determinative auction, the developing country is likely to find itself forced to offer subsidies merely because other countries offer them, not because it would choose to do so on the basis of a cost-benefit analysis independent of tax competition.

Two additional points need to be made from a developing-country perspective. The first concerns the question of tax incidence. Because the tax competition most relevant to developing countries involves the corporate income tax, it is important to assess the incidence of that tax in evaluating the welfare effects of collecting it. Unfortunately, even after decades of analysis, no consensus exists on its incidence. While older studies tended to conclude that the tax is borne exclusively by shareholders or capital providers, more recent studies suggest that the tax is borne to a significant extent by consumers or labor. ${ }^{339}$ Another possibility is that the individuals who own shares at the time of the tax's imposition or increase immediately bear the tax, which is capitalized into the price of the shares thereafter. ${ }^{340}$ It is unlikely that this debate will be resolved anytime soon (in fact, the incidence may be shifting over time, especially if globalization enables corporations to shift more of the tax burden to labor). However, from the perspective of a developing country deciding whether to collect taxes from an MNE, three out of the four possible alternatives for incidence (current shareholders or capital providers, old shareholders, and consumers) are largely residents of other jurisdictions, and therefore, the developing country gains - from a national welfare perspective - by collecting the tax. And even if some of the tax is shifted to labor in the developing country, one could argue that as a matter of tax administration,

\footnotetext{
338 See Fernand Braudel, The Mediterranean and the MediterRanean World in THE AGE OF PHILIP II, at xiv (Siân Reynolds trans., HarperCollinsPublishers 2 d rev. ed. abr. I992) (Ig66).

339 See, e.g., JOSEPH A. PEChMAN, Federal TAX POLICY I4I-46 (5th ed. I987). The I992 Treasury report on integration concluded that the tax falls on shareholders in the short run, but either on capital alone or on capital and labor in the long run. See U.S. DEP'T OF THE TREASURY, supra note 210 , at 326.

340 See PeCHMAN, supra note 339 , at 144.
} 
collecting the tax from MNEs is more efficient (as well as more politically acceptable) than attempting to collect it from workers.

The second point relates to the public versus private use of funds. A developing country may want to collect taxes from MNEs even if it generally believes that the private sector uses resources more efficiently than does the public sector. The taxes that a developing country fails to collect from a foreign MNE may indeed be used by the private sector - but in another jurisdiction, where they provide no benefit to the developing country. One solution that developing countries employ is to refrain from taxing MNEs so long as they reinvest domestically, but to tax them when they remit the profits abroad. However, such taxation of dividends and other forms of remittance is subject to the same tax competition problem that I discussed above. Thus, overcoming the tax competition problem appears in most cases to be in the interest of developing countries. The question that remains is how to do so in the face of the collective action problem described earlier.

\section{Inter-Nation Equity and the Division of Global Tax Revenues}

Having established that both developed and developing countries need tax revenue, can we decide how to divide the available revenue between them? This question relates to the concept of inter-nation equity, which Peggy Musgrave first developed. ${ }^{341}$ As she articulates it, the concept relates primarily to the question of entitlement - that is, which country was entitled to the revenue - and has been used to defend the prevalent practice of source-based taxation against the preference for residence-based taxation that accompanies CEN. ${ }^{342}$

This formulation of inter-nation equity, however, is problematic because it is vague and does not readily lead to practical recommendations. Even a preference for source- over residence-based taxation is not very meaningful without a coherent notion of the source of income. Most income comes from multiple sources, and economists have generally concluded that assigning income to a single source is a meaningless exercise (albeit a necessary one for legal and tax purposes). ${ }^{343}$ If so, then any generally acceptable sourcing rule is unobjectionable as an economic matter, but a concept of inter-nation equity that is based on sourcing offers no guidance in determining specifically how much income a country is "entitled" to tax.

\footnotetext{
341 See Musgrave, Intemational Tax Base Division, supra note 197 ; Musgrave \& Musgrave, Inter-nation Equity, supra note I 97 ; see also Kaufman, supra note 197 , at 153.

342 See Musgrave \& Musgrave, Inter-nation Equity, supra note 197 , at 73.

343 See, e.g., Hugh J. Ault \& David F. Bradford, Taxing International Income: An Analysis of the U.S. System and Its Economic Premises, in TAXATION IN THE GLOBAL ECONOMY, supra note 70, at $I \mathrm{I}, 30-3 \mathrm{I}$.
} 
Perhaps some progress can be made by relating inter-nation equity to inter-individual equity, its better-known cousin. ${ }^{344}$ It is widely accepted that redistributive income taxation can be justified by considerations of vertical equity and the declining marginal utility of income. ${ }^{345}$ But there appears to be no sound theoretical reason to restrict redistribution to members of any single tax jurisdiction. If there were a world taxing authority, it would be justified in redistributing wealth on a worldwide basis.

Given that there are many taxing jurisdictions, redistribution in practice takes place within countries, not between them, a fact that is justifiable on political grounds ("no taxation without representation"). Explicit redistribution among countries is rare, especially given widespread dissatisfaction with foreign aid. But this analysis suggests that those who design international tax rules should seek to take into account the relative wealth of the countries involved. In federal states, explicit redistributive mechanisms that transfer wealth from the richer to the poorer provinces are common. ${ }^{346}$ If there were a world federal taxing authority, it could analogously redistribute revenues from richer to poorer countries, not only directly, through transfer payments, but also indirectly, through tax rates. For example, whenever a transaction took place between two jurisdictions, the poorer one could explicitly be allowed to retain a larger share of the revenue (for example, in inverse proportion to its GDP)..$^{347}$

Currently, there is no world taxing authority, nor is one likely to be established in the near future. ${ }^{348}$ But some of the current practice of international taxation can be interpreted as reflecting concern for the relatively greater revenue needs of poorer countries. In particular, the widespread acceptance of the source country's right to levy its tax first and of the imposition of the burden of alleviating double taxation on the residence country partly reflects the position of the poorer (capitalimporting) countries in the I $920 \mathrm{~s}$. This position was accepted by the League of Nations and (subject to certain limits, such as the perma-

344 On the distinction between the two, see Kaufman, supra note 197.

345 See Kaplow, supra note 196 , at 139 , I44. For a recent exposition of the utilitarian case for progressive taxation, see Martin J. McMahon, Jr. \& Alice G. Abreu, Winner-Take-All Markets: Easing the Case for Progressive Taxation, 4 FLA. TAX REV. I (I998).

346 See, e.g., Albert J. Radler, Germany, in HUgh J. AULT, CoMparative InCOME TaXation: A STRUCTURAL ANALYSIS 49, 49 (I997)

347 See Peggy Brewer Richman [Musgrave], TAXation OF Foreign INVESTMENT INCOME: AN ECONOMIC ANALYSIS 79 (1963).

348 See infra Part V, pp. 1652-74. 
nent establishment concept) enshrined in the model treaties that form the foundation of the current international tax regime. ${ }^{349}$

Thus, I argue that the concept of inter-nation equity can be given practical meaning in the design of international tax rules if it is interpreted as embodying explicit redistributive goals. More specifically, when a choice is presented between two otherwise comparable alternative rules, one of which has progressive and the other regressive implications for the division of the international tax base between poorer and richer countries, the progressive rule should be explicitly preferred to the regressive one. In the absence of a world taxing authority that can redistribute tax revenues directly, and given the paucity of foreign aid from developed to developing countries, such a concept of internation equity has the best chance of achieving meaningful distributive goals.

The problem of tax competition, as described in Part II, is a good illustration of such a choice. The problem breaks down into two components: portfolio and direct investment. For portfolio investment, the home country of the invested capital may be either a developed or a developing country, while the host country is typically a developed country. For direct investment, the home country of the invested capital is typically a developed country, while the host country may be either a developed or a developing country. 350

Tax competition undermines the ability of both home and host jurisdictions to tax income from cross-border portfolio and direct investments. In each case, it is possible to design solutions that emphasize either home-country (residence) or host-country (source) taxation. For portfolio investment, for example, a nation could have either a final withholding tax, which would accrue to the host jurisdiction, or a refundable withholding tax, which would be refunded upon proof that the income was reported to the home jurisdiction. The first solution would favor host countries; the second, home countries. ${ }^{351}$ As home countries are, on average, poorer than host countries, inter-nation equity would suggest choosing the second solution over the first.

349 See Avi-Yonah, International Taxation of Electronic Commerce, supra note 40 , at 534-35; Reuven S. Avi-Yonah, The Structure of International Taxation: A Proposal for Simplification, 74 TEX. L. REV. I301, I303-04 (I996); Graetz \& O'Hear, supra note 314, at 1023.

350 See WORLD INVESTMENT REPORT, supra note IO4, at I8-24.

351 The EU, as section V.A.2 reports below, has opted for a two-track method in which countries can choose between the exchange of information, which favors home countries, and a refundable withholding tax, which likewise favors home countries but to a lesser extent (some investors would prefer to forego the refund if the rate were lower than the home-country rate). See Proposal for a Council Directive to Ensure a Minimum of Effective Taxation of Savings Income in the Form of Interest Payments Within the Community, COM(98)295 final at 3-5. The OECD prefers pure exchange of information. See OECD REPORT, supra note 26 , at 46. 
Similarly, for direct investment, it is possible to design a regime that allocates corporate tax revenues entirely to the home (residence) country. For example, a corporation could be assigned a residence based on the residence of its shareholders and the corporate tax revenues allocated to that country. ${ }^{352}$ Or a nation could implement a form of corporate-shareholder integration that eliminates the corporate tax base and allocates all revenues to the home country of the shareholders. ${ }^{353}$ Alternatively, the corporate tax could be abolished and shareholders taxed on their holdings on a mark-to-market basis. ${ }^{354}$ All of these solutions favor home- over host-country taxation.

Another set of potential solutions to tax competition would maintain the existing preference for host-country (source) taxation of direct investment. Part V proposes one such solution. From an inter-nation equity perspective, this solution is preferable precisely because in the direct investment context, host jurisdictions are generally poorer than home jurisdictions. ${ }^{355}$ If one accepts the need for redistribution in general, taking such distributive considerations explicitly into account in the international tax context would represent a significant step forward.

\footnotetext{
352 See Richard L. Doernberg, Electronic Commerce and Intermational Tax Sharing, 98 WORLDWIDE TAX DAllY 60-43, II 36-38 (1998), available in WL 98 WTD 60-43.

353 See Alberto Giovannini \& James R. Hines, Jr., Capital Flight and Tax Competition: Are There Viable Solutions to Both Problems?, in EUROPEAN FINANCIAL INTEGRATION $172,194-95$ (Alberto Giovannini \& Colin Mayer eds., r99I).

354 See Joseph M. Dodge, A Combined Mark-to-Market and Pass-Through CorporateShareholder Integration Proposal, 50 TAX L. REV. 265, 266-67 (1995) (proposing taxing shareholders on unrealized increases in the value of their shares); Daniel Halperin, Will Integration Increase Efficiency? - The Old and New View of Dividend Policy, 47 TAX L. REV. 645 (1992).

355 This rationale draws additional strength from the corporate tax's relative importance to developing countries, compared with its relative insignificance for most developed countries. See supra p. 1620 \& n.209. Almost none of the current literature on international taxation discusses such distributive issues. But see Chang Hee Lee, Impact of E-Commerce on Allocation of Tax Revenue Between Developed and Developing Countries, 18 TAX NOTES INT'L 2569 (I999) (discussing the likely revenue and equity impact of e-commerce on developing countries).
} 


\section{SOLUTIONS 356}

\section{A. EU Proposals and Critique}

On December I, I997, the Council of the European Union (EU) adopted a "package to tackle harmful tax competition in the European Union." 357 The package was based on the work of the Commission of the EU, particularly that of the Tax Working Group headed by Fiscal Affairs Commissioner Mario Monti. The package ultimately comprised three measures: a nonbinding "code of conduct" for business taxation; ;58 a draft directive on taxation of savings; ;59 and a draft directive on taxation of cross-border interest and royalty payments. ${ }^{360}$

r. The Code of Conduct. - In some ways the most interesting of the three proposals, the code of conduct has had a significant impact on both the actions of member states and the related work of the OECD. ${ }^{361}$ The code is a "political commitment," not a legally binding document, ${ }^{362}$ but it has the support of all member states, at least on paper.

The code addresses business tax measures that "affect, or may affect, in a significant way the location of business activity in the Community." ${ }^{633}$ The tax measures affected include any measure applied by

356 The discussion below does not consider the possibility that the mobility of capital could or should be restricted directly. Most economists would reject such proposals, and no scholar advocates them for longer-term investments. For the development of the OECD's view, see OECD, CONTROLS ON INTERNATIONAL CAPITAL MOVEMENTS (I982); CENTRE FOR CO-OPERATION WITH THE EUROPEAN ECONS. IN TRANSITION, OECD, EXCHANGE CONTROL POLICY (I993); and OECD, OPEN MARKETS MATTER: THE BENEFITS OF TRADE AND INVESTMENT LIBERALISATION (1998). But see BO SANDEMANN RASMUSSEN, INTERNATIONAL TAX COMPETITION, TAX CoOperation AND CAPITAL CONTROLS (Univ, of Aarhus, Den., Dep't of Econ. Working Paper No. 1997-9, 1997) (arguing that even though capital controls are inferior to cooperation, threats to impose such controls may be useful in persuading countries to cooperate in tax matters).

357 Conclusions of the ECOFIN Council Meeting on I December 1997 Concerning Taxation Policy, I 998 O.J. (C 2) I, I [hereinafter Conclusions of the ECOFIN Council].

358 Resolution of the Council and the Representatives of the Governments of the Member States, Meeting within the Council, of I December I 997 on a Code of Conduct for Business Taxation, I 998 O.J. ( $\mathrm{C}_{2}$ ) 2, 2 [hereinafter Code of Conduct].

359 See Commission Proposal for a Council Directive to Ensure a Minimum of Effective Taxation of Savings Income in the Form of Interest Payments within the Community, COM(98)295 final at II-Ig [hereinafter Draft Directive on Savings].

360 See Commission Proposal for a Council Directive on a Common System of Taxation Applicable to Interest and Royalty Payments Made between Associated Companies of Different Member States, $\operatorname{COM}(98) 67$ final at II-I 8 [hereinafter Draft Directive on Interest and Royalties]. Under Article 100 of the Treaty of Rome, the draft directives require the unanimous consent of the Council for adoption. See TREATY EsTablishing THE EUROPEAN ECONOMIC COMMUNITY, Mar. 25, 1957, art. 100, 298 U.N.T.S. II, 54 [hereinafter TREATY OF ROME].

361 For a description and critique of the OECD proposals, see below at pp. 1657-66.

362 Code of Conduct, supra note 358 , preamble II 6 , at 3 .

363 Id. $8 \mathrm{~A}$, at 3 . 
law, regulation, or administrative practice, whether through the nominal tax rate, the tax base, or "any other relevant factor."364 "Business activity" is defined broadly as including all activities carried out within a company or a group of companies. ${ }^{365}$ In addition, the ministers bound themselves to reexamine subsidies delivered outside the tax system. ${ }^{366}$

The code covers all tax measures that "provide for a significantly lower effective level of taxation, including zero taxation, than those levels which generally apply in the Member State in question."367 Such measures are considered "potentially harmful."368 In determining whether they are in fact harmful, several other factors are considered, including: whether the tax measures apply only to nonresidents; whether the measures are "ring-fenced," or segregated from the domestic market to prevent erosion of the domestic tax base; whether advantages are granted without any real economic activity or substantial economic presence in the member state; whether the state follows the OECD transfer pricing guidelines (to prevent artificial allocation of profits to the activity benefiting from the measure); or whether the measure lacks transparency (for example, if it is granted by covert administrative action). ${ }^{369}$

The code envisions two forms of enforcement. First, member states will engage in a self-review process and commit themselves not to introduce new tax measures that are deemed harmful under these criteria ("[s]tandstill") and to eliminate existing harmful measures within a two-to-five-year period ("[r]ollback").370 Second, member states will inform each other about their preferential tax regimes, and any member state may request an opportunity to discuss and comment on the tax measures of other member states. For this purpose, the code pro-

364 Id. $8 \mathrm{~B}$, at 3 .

365 Id. $8 \mathrm{~A}$, at 3 .

366 See Conclusions of the ECOFIN Council, supra note 357 , at I; Code of Conduct, supra note 358, § J, at 5; Nigel Tutt, European Commission to Propose Guidelines on Providing State Aid Through Tax System, 98 WORLDWIDE TAX DAILY 135-3 (1998), available in WL 98 WTD 135-3. The Treaty of Rome limits state aid. See TREATY OF ROME, supra note 360, arts. 92-94, 298 U.N.T.S. at $5 \mathrm{I}-52$. On the particular problem of regional development programs, see Code of Conduct, supra note $358,8 \mathrm{G}$, at 4 .

367 Code of Conduct, supra note $358,8 \mathrm{~B}$, at 3.

368 Id.

369 Id. $8 \S \mathrm{B}(\mathrm{I})-(5)$, at 3 . Germany took the position that paragraph 3 applies to the targeted granting of advantages for international mobile activities when they are not granted for nonmobile activities. See Conclusions of the ECOFIN Council, supra note 357, at 2.

370 Code of Conduct, supra note $358, \$ 8 \mathrm{C}-\mathrm{D}$, at 4 ; see Conclusions of the ECOFIN Council, supra note 357 , at $1-2$. The Council may approve a longer period in some circumstances. 
poses forming a review group to assess those measures and forward a report to the Council, which may publish it. ${ }^{371}$

Thus, the idea is to exert political pressure through the review process to influence member states that have established either production tax havens (such as Ireland) or headquarters tax havens (such as Belgium) to abolish them. In fact, Ireland announced soon after the code's promulgation that it was phasing out its preferential tax regimes and replacing them with a single, lower rate of corporation tax applicable to all companies (whether domestic- or foreign-owned). ${ }^{372}$

The code also requires member states to "promot[e]" the adoption of similar principles in other countries and to apply them to "dependent or associated territories," such as the Channel Islands. ${ }^{373}$ The United Kingdom has in fact already begun to pressure its dependencies to adopt the code's principles. ${ }^{374}$

2. Taxation of Savings. - At the code-of-conduct meeting (chaired, ironically, by Luxembourg), the EU Council adopted another resolution on taxation of savings, which would apply a new regime to interest income paid to individual residents of the EU by paying agents located in another member state. 375 The Commission in May 1998 proposed a draft Directive on this topic for adoption by the Council. ${ }^{376}$

The draft Directive proposes a "coexistence" model based on two options: each member state must either cooperate in an exchange-ofinformation program or levy a withholding tax on interest payments disbursed by agents within its territory to individual residents of another member state. ${ }^{377}$ Under the exchange-of-information system, the member state would agree to provide, automatically and annually, information on all interest payments made by paying agents in its territory in the preceding year to individual beneficial owners residing in every other member state. ${ }^{378}$ Under the withholding tax system, the member state would agree to levy a $20 \%$ withholding tax on all such payments unless the beneficial owner provided a certificate from his country's tax authorities attesting that they had been informed of the

\footnotetext{
371 See Code of Conduct, supra note $358, \$ 8 \mathrm{E}-\mathrm{I}$, at 4-5. For the formation of the Code of Conduct Group, see Report of the 2072nd Council Meeting (Mar. 9, 1998), 66Ig/98 (Presse 6I), C/98/6r, at Io-1 2 (on file with the Harvard Law School Library).

372 See Edward Troup \& Paul Hale, EU Initiatives on Tax Harmonization: Do as I Say, Not as I Do?, i 7 TAX NOTES INT'L 108 I, 1082 (I998).

373 Code of Conduct, supra note $358,8 \mathrm{M}$, at 5 .

374 See Jim Kelly, Relegation Threat Looms, FIN. TIMES (London), July I5, I999, § 2, at I I.

375 See Taxation of Savings, I998 O.J. (C 2) 6, 6.

376 See Draft Directive on Savings, supra note 359 , at I I -14.

377 See id., art. 2, at 14.

378 See id., art. 7 , at 16.
} 
interest to be received. ${ }^{379}$ The withholding tax would be credited against tax liability in the beneficial owner's country of residence. ${ }^{380}$

This draft Directive has encountered significant opposition. Industry groups have argued that it will result in an outflow of savings from the EU to, among other countries, Switzerland. ${ }^{381}$ More significantly, both Luxembourg and the United Kingdom have opposed the Directive, anticipating an adverse impact on the Eurobond market. ${ }^{382}$ Luxembourg announced that it would not support the Directive unless the EU's main trading partners accepted parts of the plan. ${ }^{383}$

3. Taxation of Interest and Royalties. - This proposal is the least controversial element of the package. The draft Directive calls for the abolition of withholding taxes on interest and royalty payments made within the EU between "associated companies," defined by a $25 \%$ ownership threshold. ${ }^{384}$ However, the tax reduction would not apply when the interest or royalty payment was subject to a corporate tax rate in the country of residence lower than the generally applicable rate or benefits from a preferential reduction in the tax base. ${ }^{385}$

4. Critique. - A fundamental problem of the $\mathrm{EU}$ tax competition package is its lack of a full-fledged normative grounding for the measures it proposes. The Council resolution mentions three reasons to address harmful tax competition: to prevent distortions in the single market, to prevent "excessive" losses of tax revenue, and to "get[] tax structures to develop in a more employment-friendly way."386 Moreo-

379 See id., art. 8, at 17 .

380 See id., art. Io, at $17-18$. If the withholding tax exceeded tax liability, a refund would be provided.

381 See Impact Assessment Form, COM(98)295 final at 22-24 (reporting statements of the European Mortgage Federation and the Banking Federation of the European Union); David L. Cleeton, European Finance Groups Respond to ECOFIN Cross-Border Savings Directive, I 7 TAX NOTES. INT'L 874, 874 (1998) (referencing a study by the International Securities Markets Association and the International Primary Markets Association).

382 See Conclusions of the ECOFIN Council, supra note 357, at 2 (U.K. position); Jonathan Annells, U.K. Chancellor Renews Attack on EC's Eurobond Tax Plan, I 7 TAX NOTES INT'L I044, 1044-45 (1998); Nick Antonovics, European Union Finance Ministers to Debate Tax Savings Plan, I TAX NOTES INT'L 946, 946 (1998). The International Primary Markets Association estimated that about $5 \%$ of existing Eurobond issues might become callable if the plan were adopted. See Troup \& Hale, supra note 372 , at 1082 .

383 See Luxembourg Says No Agreement Reached on EU Savings Tax, 7 TAX NOTES INT'L I039 (I998).

384 Draft Directive on Interest and Royalties, supra note 360 , art. I, at I2; see id. art. 3 (r)(b), at 14.

385 See id. art. 7 , at $\mathrm{I} 6$. This article is to be reviewed in three years.

386 Conclusions of the ECOFIN Council, supra note 357 , at 1 . The rationale for the relationship between employment and tax competition is that tax competition increases the tax burden on (immobile) labor relative to (mobile) capital. The increased taxes on employment result in a loss of jobs. See Draft Directive on Savings, supra note 359, at 3; European Parliament, Resolution on the Commission Communication 'A Package to Tackle Harmful Tax Competition in the European Union' (COM(97)0564), I998 O.J. (C 2 10) $227,227$. 
ver, the package cites the transition to the European Monetary Union as increasing the mobility of capital in the EU.387 However, the proposal's authors do not develop any of these reasons in detail, leaving the package open to criticism as being opportunistic and unbalanced. 388

In light of the normative argument developed in Part III above, however, the EU package seems quite reasonable; it addresses the problems of inefficiency, inequity, and tax-base erosion in a way that provides sufficient freedom to member states to define the size of their public sectors as they desire. In particular, the package maintains the distinction between generally applicable tax reductions and measures aimed only at foreigners; this distinction has proven effective, as the Irish example illustrates. In addition, the Savings Directive appropriately aims at ensuring that a saver will be taxed in his country of residence.

The EU package does suffer, however, from a major limitation: It applies only within the EU. Thus, as far as the preferential regimes addressed in the code of conduct are concerned, only regimes in EU member states are affected. However, as described in Part II, both production tax havens and headquarters tax havens have proliferated outside the EU. Although the code envisions "promoting" its principles in nonmember countries, ${ }^{389}$ it has little impact outside the dependent territories. This does not mean, however, that the code has no impact at all. Locating within the EU provides a firm significant advantages in trading with EU member countries, which gives the code of conduct significant bite, because production or headquarters tax havens located outside the $\mathrm{EU}$ will not benefit from the same advantages as those in Ireland, Belgium, or any other EU member country. ${ }^{390}$ Nevertheless, from a global perspective, the code's reach is quite limited, and given the reduction in transportation costs, it seems likely that multinationals will be able to locate their activities in production tax havens outside the EU.

A more significant problem faces the draft Directive on Savings. Fear that this proposal would drive capital away from EU members and to Switzerland or the United States may impede its adoption. The drafters sought to address this problem by limiting the Directive's application to interest payments made to EU residents. ${ }^{391}$ This limita-

\footnotetext{
387 See Draft Directive on Savings, supra note 359, at 2.

388 See, e.g., Troup \& Hale, supra note 372.

389 See Code of Conduct, supra note $358, \S \mathbf{M}$, at 5 .

390 The EU package may, however, encourage companies to locate in countries like Israel, which has a free-trade agreement with the EU but is not a member.

391 This provision would allow EU countries to continue to attract capital from outside the EU without having to impose a withholding tax on such capital.
} 
tion diminishes the Directive's attractiveness from a global perspective. In addition, the focus on paying agents rather than debtors means that U.S. issuers raising capital in Europe will, to some extent, have no direct competitive advantage over European issuers. ${ }^{392}$ Finally, the Directive envisions the EU taking measures "to promote the adoption in third countries of equivalent measures relating to payments of interest to Community residents." 393 However, as Luxembourg's reaction makes clear, requiring the imposition of a $20 \%$ withholding tax risks shifting the savings of EU residents (for example, German residents) ${ }^{394}$ to non-EU countries.

In addition, even if the Directive were implemented, it would only alleviate, not solve, the problem of under-taxation of interest income. A $20 \%$ rate is far from sufficient to compensate for nontaxation in the home country (at rates of $50 \%$ or higher). ${ }^{395}$ However, the EU concluded that a higher rate would be more likely to drive capital out of the Community. ${ }^{396}$ In this way, the proposal resembles the Nordic "dual tax" system, under which capital is taxed at a much lower rate than labor to ensure that it is subject to at least some tax. ${ }^{397}$ Although the Directive is a start, it cannot serve as a complete solution.

The obvious solution is to expand the scope of the EU proposals to nonmember countries. Some ways to accomplish this are discussed in section V.C.

\section{B. OECD Proposals and Critique}

I. The OECD Report. - The OECD Report, entitled Harmful Tax Competition: An Emerging Global Issue, was approved by the OECD Council on April 9, 1998, with two abstentions (Luxembourg and Switzerland). ${ }^{398}$ The Report was written by the "Special Sessions on Tax Competition," which was co-chaired by France and Japan under the auspices of the Committee on Fiscal Affairs. The introduction explains the Report's goals:

392 See Draft Directive on Savings, supra note 359, at 4. The Directive also notes that the Eurobond Market is to a large extent composed of institutional investors and non-EU residents, who would not be affected by the proposal. See id.

393 Id. at 20.

394 See supra p. 1583.

395 This argument makes the realistic assumption that host countries do not offer significant deductions for interest income to individual taxpayers.

396 See Draft Directive on Savings, supra note 359, at 3. The French argued that the rate should be set no lower than $25 \%$. See Conclusions of the ECOFIN Council, supra note 357 , at 2.

397 See Timo Viherkentta, A Flat Rate Tax on Capital Income: The Nordic Model, 6 TAX NOTES INT'L 659, 659-6I (I993).

398 See OECD REPORT, supra note 26, at 65. Although most of the OECD's 29 members are considered developed countries, the organization also includes some developing countries (such as Mexico and South Korea) and some transition economies (such as the Czech Republic, Hungary, and Poland). 
[T]o develop a better understanding of how tax havens and harmful preferential tax regimes, collectively referred to as harmful tax practices, affect the location of financial and other service activities, erode the tax bases of other countries, distort trade and investment patterns and undermine the fairness, neutrality and broad social acceptance of tax systems generally. 399

Thus, on the one hand, the OECD Report maintains a narrower focus than the EU package. It does not address the taxation of crossborder interest flows; that issue is to be the topic of a separate report, which was scheduled to be issued in 1999 by a Working Party on Tax Evasion and Avoidance. ${ }^{400}$ In addition, the Report focuses entirely on "geographically mobile activities, such as financial and other service activities, including the provision of intangibles."401 The Report explains that the issue of tax competition for "real" investments will be examined separately in the future but does not commit itself to a date. ${ }^{402}$ According to Hugh Ault, who served as academic consultant to the OECD and participated in drafting the Report, this matter was postponed "in the interest of creating a manageable work plan." ${ }^{403}$

On the other hand, because of its provenance, the OECD Report applies to a much broader geographical area than does the EU package. In addition to binding twenty-seven of the twenty-nine OECD members, the Report envisages that the OECD will attempt to persuade nonmember countries to abide by its recommendations. Three regional seminars with nonmember countries have already been held, and the Report proposed that a high-level meeting open to nonmember countries be organized in $1999 .{ }^{404}$ Moreover, the OECD Report places much greater emphasis on traditional tax havens than does the EU package.

Chapter I of the Report sets out its normative basis. The Report barely mentions economic distortions and never mentions CEN at all. Instead, it focuses on tax-base erosion and the change in the tax mix:

[T]hese schemes can erode national tax bases of other countries, may alter the structure of taxation (by shifting part of the tax burden from mobile to relatively immobile factors and from income to consumption) and may hamper the application of progressive tax rates and the achievement of redistributive goals. ${ }^{405}$

\footnotetext{
399 Id. at 8.

400 See id. at 10. The second report is still pending.

401 Id. at 8.

402 See id.

403 Joann M. Weiner \& Hugh J. Ault, The OECD's Report on Harmful Tax Competition, I I NAT'L TAX J. 601, 602 (I998).

404 See OECD REPORT, supra note 26 , at to.

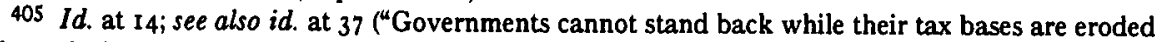
through the actions of countries which offer taxpayers ways to exploit tax havens and preferential
} 
However, the Report does not set out any of these points in detail. ${ }^{406}$ In particular, the Report introduces no evidence to support the assertion that the tax base of OECD members is being eroded. ${ }^{407}$ Chapter I does attempt to distinguish between regimes that intend to "poach" the tax base of other countries and regimes that "reflect different judgments about the appropriate level of taxes and public outlays or the appropriate mix of taxes in a particular economy."408 However, it makes no systematic effort to distinguish on a normative basis between harmful and beneficial tax competition, as Part III attempts to do.

Because of the absence of an overt normative framework, one must divine the line that the OECD draws between beneficial and detrimental tax competition from the characteristics of tax havens and harmful preferential tax regimes listed in Chapter 2 of the Report. The OECD draws a distinction between, on the one hand, tax havens and preferential regimes in countries that have generally applicable taxes, and on the other hand, generally applicable tax rates that are lower than those of other countries. ${ }^{409}$ Chapter 2 acknowledges that all three situations may have negative effects from the perspective of a high-tax country but explicitly excludes the third category from the scope of the Report.410

A major contribution of the OECD Report is that it lists factors to be used in identifying tax havens." The OECD factors are: "[n]o or only nominal taxes" (a necessary condition); a "[l]ack of effective exchange of information"; a "[l]ack of transparency"; and the absence of any requirement for "substantial activities" by the taxpayer in the jurisdiction. ${ }^{412}$ These objective factors are superior to the previous attempt by the OECD to identify tax havens based on reputation, or a "smell test," because reputation is in the eye of the beholder. ${ }^{413} \mathrm{Al}$ though the Report itself does not attempt to identify specific countries as tax havens, it does establish a Forum on Harmful Tax Competition,

regimes to reduce the tax that would otherwise be payable to them."). This emphasis is unfortunate, given both the paucity of the evidence and the impression it gives of government bureaucrats trying to protect their cherished tax revenues; it certainly does nothing to combat the Leviathan critique.

406 The entire chapter contains only five and a half pages.

407 See id. at 17 ("The available data do not permit a detailed comparative analysis of the economic and revenue effects [of tax competition]."). The Report does note that FDI by $G_{7}$ countries in the Caribbean and in the South Pacific islands increased more than five-fold, to over $\$ 200$ billion, between 1985 and 1994 , a rate well in excess of the growth of total outbound FDI. See id.

408 Id. at 16.

409 See id. at $19-20$.

410 See id. at 20.

411 Because the EU contains no traditional tax havens, it neglected to include such a list of factors in its package.

412 Id. at 23 box I.

413 See Weiner \& Ault, supra note 403 , at $602-03$. 
which has begun to assemble a list. In fact, the Forum has already asked one country - Bermuda - to explain why it should not be labeled a tax haven. ${ }^{414}$

The Report also lists characteristics to be used in identifying "harmful preferential tax regimes."415 These characteristics resemble the factors defined in the EU Code of Conduct, except that the OECD list is limited to financial and service activities. The factors are: "[n]o or low effective tax rates" (a necessary condition); "ring fencing" (that is, separation from the domestic tax base); a lack of "transparency" and of "effective exchange of information"; an "artificial definition of the tax base"; "[f]ailure to adhere to international transfer pricing principles"; the exemption of foreign source income from tax; a negotiable tax rate or base; "secrecy provisions" such as bank secrecy laws or bearer debt; membership in "a wide network of tax treaties"; selfpromotion as "tax minimisation vehicles"; and the "[e]ncouragement of tax-driven operations." 416 The first four factors are identified as "key"; the other factors are less significant. ${ }^{417}$

In addition, the Report lists three questions that may be asked to help identify whether a preferential tax regime is harmful:

Does the tax regime shift activity from one country to the country providing the preferential tax regime, rather than generate significant new activity?

Is the presence and level of activities in the host country commensurate with the amount of investment or income?

....

Is the preferential tax regime the primary motivation for the location of an activity? ${ }^{418}$

However, because these questions are difficult to answer and the Report offers little guidance, I doubt they will add much to the objective factors identified above. ${ }^{419}$

Chapter 3 of the OECD Report is the most important. It contains nineteen recommendations, divided into three categories: domestic legislation that each member may adopt unilaterally; tax treaties; and

414 See Ahmed ElAmin, OECD Panel Reportedly Met in Paris to Address Tax Haven Inquiry, 98 WORLDWIDE TAX DAILY 20I-7 (rg98), available in WI. 98 TNI $201-7$.

415 OECD REPORT, supra note 26 , at 27 box II.

416 Id. at 27 box II, 27-34.

417 See id. at 27,30 .

418 ld. at 34-35 (emphasis omitted).

419 In particular, even if it is impossible to show a prohibited motive, the OECD should presumptively treat regimes that qualify as preferential under the objective criteria as harmful. See Troup \& Hale, supra note 372 , at 1082 (questioning the appropriateness of tests based on a country's motivation). Relying on taxpayer motivations is no more helpful. 
intensifying international cooperation. ${ }^{420}$ In addition, the chapter contains "Guidelines for Dealing with Harmful Preferential Tax Regimes in Member Countries." 421 These guidelines resemble the EU Code of Conduct; they represent a nonbinding political commitment by the OECD members (except, importantly, Luxembourg and Switzerland) to eliminate their preferential tax regimes. The guidelines contain three R's: to refrain, to review, and to remove. The twenty-seven member states bind themselves to refrain from adopting new harmful tax practices (as defined in Chapter 2). They also agree to review their existing measures and report to the Forum on their harmful tax practices within two years. The member states also commit to remove those practices within five years. ${ }^{422}$

Finally, the Report recommends establishing a Forum on Harmful Tax Practices, which has in fact been established ${ }^{423}$ and whose main goals are: to establish a list of countries that maintain tax havens; to review potentially harmful tax practices by member countries (which may argue that their practices are not harmful) and coordinate responses to harmful practices by nonmembers; and to "encourage actively non-member countries to associate themselves with" the Guidelines. ${ }^{424}$ Any member may request review of another member's practices by the Forum, which may issue a nonbinding opinion. As Weiner and Ault note, the establishment of the Forum may be "the most important achievement" of the Report because it is the "first broadly mandated international institutional structure directly responsible for the evaluation and coordination of existing and proposed tax measures."425 Although the opinions of the Forum are not legally binding, they are likely to have a significant stigmatic impact on member states who are found to have violated their commitment to the guidelines. ${ }^{426}$

Luxembourg and Switzerland abstained from the vote on the Report and are therefore not bound by it.427 Luxembourg objected chiefly to the fact that the Report, "[b]y voluntarily limiting itself to fi-

420 The most practically relevant of these recommendations are that member countries should adopt controlled foreign corporation and foreign investment fund rules and should restrict the application of the exemption method in a fashion consistent with the desirability of curbing harmful tax practices.

421 OECD REPORT, supra note 26 , at 56 box III.

422 See id. at 56-57. The final deadline for completing removal is December 31, 2005. See id. Ireland has agreed to eliminate its Dublin International Financial Services Center, which allows holding companies to be taxed at a I0\% rate, by that date. See Walsh, supra note II 7, III 2-3.

423 See id. at 66; see also Weiner \& Ault, supra note 403 , at 601 .

424 OECD REPORT, supra note 26 , at 57.

425 Weiner \& Ault, supra note 403 , at 606

426 See id.; supra note 422 (noting the example of Ireland).

427 See OECD REPORT, supra note 26 , annex II, at 73-75. 
nancial activities ... adopts a partial and unbalanced approach."428 In addition, Luxembourg noted its opposition to any future extension of the underlying philosophy of the report (namely, exchange of information) to the taxation of interest and proposed the EU's co-existence model instead. ${ }^{429}$ Because any member can block Council recommendations, this threat is credible.

Switzerland seconded Luxembourg's objection to the Report's emphasis on financial activities and to its implied rejection of the coexistence model. It also objected to including lower tax rates as a criterion for identifying harmful preferential tax regimes, despite the fact that this criterion is never sufficient by itself. Switzerland argued that the latter "results in unacceptable protection of countries with high levels of taxation." 430 However, "[a]fter having seriously considered the possibility of exercising its veto," Switzerland decided to abstain "in order not to prevent [the] adoption [of the Report] by other OECD Member countries wishing to do so."431

2. Critique. - The OECD Report is a major achievement; it represents the first attempt to limit harmful tax competition to be based on a broad consensus of many nations, including developing countries. ${ }^{432}$ It is particularly remarkable that Switzerland and Luxembourg, which, as financially-oriented tax havens, are the most affected by the recommendations, chose not to veto the Report. This probably reflects their judgment that doing so would subject them to an unacceptable level of criticism from the other OECD member countries, and therefore may demonstrate that a broad consensus on the principal goals of the Report has indeed developed.

Thus, the OECD Report is an indispensable first step in the process of limiting harmful tax competition. The Forum that it establishes promises to provide the institutional framework for further development in this area and may (as suggested in Part VI) become the initial kernel of a "world tax organization." The development of any further limits on harmful tax competition must realistically be based on what the OECD has achieved, which represents the most promising signal that further work can usefully be done in this area.

However, the OECD Report does suffer from several problems and limitations, some of which may have inevitably resulted from the political compromises needed to achieve consensus within a diverse group of twenty-seven countries. I discuss four such limitations. First, the normative grounding (Chapter I) is far too cursory to be persua-

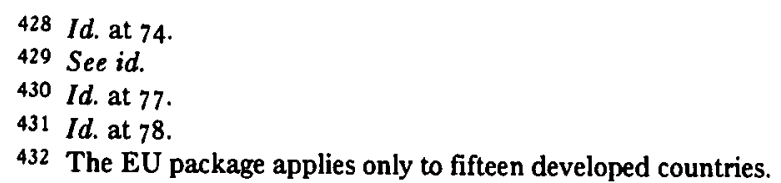


sive. ${ }^{433}$ The emphasis on tax-base erosion, as opposed to the potential beneficial uses of increased tax revenues, leaves the Report open to the Leviathan critique - that it is merely an attempt by the governments of high-tax countries to protect their tax revenues even if their citizens would benefit from lower taxes. ${ }^{434}$ This lack of thoroughness is particularly troubling because it is unnecessary: the OECD does present sufficient data to support its tax-base erosion argurnent. It would have been better to have set out more fully the efficiency and equity considerations.

Second, although the line drawn between acceptable and harmful tax competition is the right one (that is, it distinguishes between generally applicable tax reductions and tax regimes that are limited to foreign investors as well as traditional tax havens), the emphasis on whether the country intended to adopt a "beggar thy neighbor" policy is unfortunate because it invites fruitless inquiries into subjective motivation. It would have been better to have focused on objective factors and to draw the line based on considerations of democracy and on the benefits and costs to the investors.

Third, the self-imposed limitations of the OECD Report are problematic, although they were probably politically necessary. ${ }^{435}$ The OECD deferred the topic of taxation of interest (originally to 1999), but given the threat of a Luxembourg veto, it is unclear whether a report on this topic has any chance of being adopted, particularly if the OECD continues to adhere to exchange of information as the main mechanism. ${ }^{436}$ More troubling is the Report's self-limitation to financial activities and services; it lacks even a timetable for extending the Report to real activities. Given the proliferation of production tax havens and the reductions in transportation costs, ${ }^{437}$ real activities are just as subject to harmful tax competition as are financial and service activities, even if they are less mobile in the short run.

Finally, the most important limitation of the OECD Report is similar to the main problem of the EU package: its direct application is restricted to OECD members (excluding Luxembourg and Switzer-

433 See supra pp. 1655-56.

434 For an unpersuasive version of this critique, see Arthur W. Wright, Review: OECD Harmful Tax Competition Report Falls Short, I7 TAX NOTES INT'L 46I, 463 (I998). But see Jan Francke, Letter to the Editor, The 1998 OECD Report on Harmful Tax Competition: Just Right, I 7 TAX NOTES INT'L 979 (1998) (disputing Wright's claims); Eric Osterweil, Letter to the Editor, In Defense of the OECD Report on Harmful Tax Competition, 77 TAX NOTES INT'L 895 (1998) (same).

435 I suspect that the reasons Luxembourg and Switzerland wanted to include real activities in the Report were not just that they are mainly havens for financial activities, but also that they knew such an inclusion would delay the Report.

436 Withholding taxes are mentioned as a "topic for further study." OECD REPORT, supra note 26 , at 60 .

437 See supra Part II, pp. I579-1603. 
land). Although the OECD measures cover a broader scope than the EU package, that scope is far from sufficient. How can these reforms be extended to nonmember countries?

The increasingly wide adoption of the OECD transfer pricing guidelines by nonmember countries and the increasing use of the OECD model treaty, even by developing countries, are encouraging indications that the suspicion of the OECD as the "rich countries' club" has abated somewhat. After all, the OECD now includes several countries that are classified by the World Bank as developing.438 Thus, it seems likely that the Forum will be able to persuade many nonmember countries, especially prospective members, to abide by the Guidelines. ${ }^{439}$ However, as the examples of Luxembourg and Switzerland indicate, other nonmember countries that have preferential tax regimes, as well as the traditional tax havens, are unlikely to cooperate. ${ }^{440}$

Thus, the key question in evaluating the Report is whether its recommendations will enable the OECD to curb tax competition by uncooperative nonmember countries. The main goal of such recommendations is to expand the use of CFC and foreign investment fund (FIF) regimes. ${ }^{441}$ The other recommendations, which focus on administrative measures, ${ }^{442}$ are likely to be helpful but not decisive.

CFC and FIF regimes (such as Subpart F and Passive Foreign Investment Company (PFIC) rules ${ }^{443}$ in the United States) are ways of subjecting low-taxed foreign income to current taxation in the taxpayer's country of residence. Specifically, CFC regimes apply to corporate taxpayers and require them to include currently in their income certain types of income of their foreign subsidiaries. The types of income usually covered are classified either by category (for example, passive income) or by source (for example, income from low-tax jurisdictions). FIF regimes apply to individual shareholders and require

\footnotetext{
438 These countries are Turkey, Mexico, the Czech Republic, Hungary, Poland, and South Korea. 439 Both South Korea and Mexico adopted the transfer pricing guidelines as the price of their admissions to the OECD. See Ken Cook \& Yasuko Masaki, Korea's New International Tax Coordination Law, I 2 TAX NOTES INT'L 243, 243-44 (I996); John A. McLees, John G. Wilkins \& Ignacio Valdes V, Tax Advisors' Forum: Extension of Mexican Assets Tax Complicates Transfer Pricing for Maquiladoras, Io TAX NOTES INT'L I6Ig, I62 I (I995).

440 This possibility is acknowledged in the Report. See OECD REPORT, supra note 26, at 20. The Report argues that countries with preferential tax regimes are more likely to want to cooperate because they have revenues to protect, but the Luxembourg and Switzerland cases raise doubts as to the validity of this prediction.

441 See id. app. Recommendation I deals with CFC regimes, Recommendation 2 with FIF regimes, and Recommendation 3 with the related problem of countries with exemption systems. See id. app. at 67 .

442 See id.

443 See I.R.C. 88 I291-98 (I994 \& Supp. IV I998).
} 
them to report (or to pay an interest charge on) income from foreign investment vehicles.

Relying on CFC and FIF regimes is problematic in several ways. First, existing regimes are filled with loopholes. Even Subpart F, which is the world's strictest CFC regime, has broad exceptions for active business income and for income derived from the active conduct of a financial business. ${ }^{444}$ The OECD Report merely recommends that member countries "consider" applying CFC and FIF regimes "in a fashion consistent with the desirability of curbing harmful tax practices." 445 Unless OECD members make a stronger commitment, they may not be able to resist the lobbying pressures of their multinationals to restrict CFC rules in the name of competitiveness. ${ }^{446}$

Second, even if OECD members could adopt broad CFC and FIF rules that applied to all the activities identified as harmful tax practices, such rules might not suffice to curb harmful tax competition. With regard to FIF rules, the problem (as explained in Part II) is an administrative one: individuals who reside in one OECD member can invest in another OECD member through a tax-haven entity and escape the exchange-of-information net. It is not clear whether the "greater and more efficient" exchange of information envisaged by the OECD Report can overcome this problem.447 Terminating tax treaties with tax havens and otherwise limiting treaty benefits would have no effect as long as there existed non-treaty-based exemptions from withholding on interest earned by nonresidents. ${ }^{448}$

Scope, rather than enforcement, limits the effectiveness of CFC rules. Even if CFC rules were to apply to all tax havens and preferential tax regimes, they still would apply only to multinationals whose parents were residents of an OECD member. Currently, about eightyfive percent of MNEs meet that description, ${ }^{449}$ but were CFC rules significantly expanded, they would probably gradually shift their residences to Luxembourg, Switzerland, or countries entirely outside the

\footnotetext{
444 This last provision, enacted on a "temporary" one-year basis in I 997 and extended in I998, runs directly contrary to the spirit of the OECD Report.

445 OECD REPORT, supra note 26 , at $40-43$.

446 The debate around I.R.S. Notice 98- I I, I 998-I C.B. 433, and the current effort to limit Subpart $\mathbf{F}$ to passive income demonstrate the existence of these pressures within the U.S. tax system. See Preface to NFTC PROJECT, supra note 33 ("American multinationals increasingly voice their concern that the Internal Revenue Code places them at a competitive disadvantage .... .").

447 OECD REPORT, supra note 26, app. at 68 (Recommendation 8); see also id. at 67 (Recommendation 4) (urging the adoption of foreign income reporting rules and the exchange of information obtained under those rules). An interest charge would work only if the income were eventually distributed to an OECD member country rather than enjoyed through consumption overseas.

448 See id. at 68-69 (Recommendations 9, I I-I2) (asking countries to deny treaty benefits to the beneficiaries of harmful tax competition, providing for a list of treaty mechanisms used to deny benefits in this way, and suggesting that countries terminate treaties with tax havens).

449 See WORLD INVESTMENT REPORT, supra note I04, at 5-6 tbl.I.I.
} 
OECD. In addition, the parent corporations of new MNEs would be incorporated or managed and controlled from outside the OECD. In particular, the headquarters tax havens of the world, many of which, such as Singapore, are outside the OECD, are likely to welcome any expansion of CFC rules by the OECD.

The OECD Report does recommend as a "topic for further study" a review of the residency rules. It acknowledges that both country of incorporation and country of management and control are "easily manipulated," and recommends focusing instead on the residence of the shareholders. ${ }^{450}$ However, because most multinationals' shares trade on several exchanges, establishing a single country of residence in this way might prove difficult. Furthermore, different CFC rules might apply at different times as shares changed hands. In addition, given the widespread use of nominees, it is far from clear that the residence of a shareholder of a publicly traded MNE can be known. ${ }^{451}$

Thus, the solutions offered by the OECD Report to the problem of harmful tax competition represent an indispensable first step toward limiting harmful tax competition, but they are incomplete. The next section represents a preliminary attempt to develop a better approach that combines the best elements of the EU package and the OECD Report with some suggestions of my own.

\section{Recommended Proposals}

The following two proposals build on the work of the EU and the OECD described in the previous sections. The first proposal addresses the under-taxation of cross-border portfolio investment, and the second proposal addresses the same issue for direct investment. Both proposals emphasize actions that the OECD can take without securing the approval of traditional, production, or headquarters tax havens. The proposals therefore focus on ways by which those countries (OECD members) most likely to want to tax the income on such investment may do so. In the case of portfolio investments, because low-risk,

450 OECD REPORT, supra note 26 , at 60-6I. For a similar suggestion, see Doernberg, supra note 352, II 36; and Howard E. Abrams \& Richard L. Doernberg, How Electronic Commerce Works, I 4 TAX NOTES INT'L 1573 (I997).

451 A more feasible suggestion is to abandon the corporate-level tax and to focus on taxing the shareholders either by imputation, which is administratively cumbersome, or by marking their shares to market. See Dodge, supra note 354, at 334-64; Robert A. Green, The Future of SourceBased Taxation of the Income of Multinational Enterprises, 79 CORNELL L. REV. I8, 70-74 (I993). As I have argued elsewhere, however, source countries are unlikely to give up their right to the corporate tax when shareholders are residents of other countries. See Avi-Yonah, International Taxation of Electronic Commerce, supra note 40, at 530. Nor, as a matter of inter-nation equity, should they do so. See Musgrave \& Musgrave, Inter-nation Equity, supra note 197. Retaining corporate-level taxes would require combining mark-to-market rules (or a PFIC-like interest charge) with complex foreign tax credit rules. 
high-return investments exist primarily in OECD member countries, the host country into which the investment is made can levy the tax. In the case of direct investment, because countries in which goods and services are consumed are likely to wish to tax (there are few, if any, "consumption tax havens"), the country of consumption can levy the tax. In both cases, however, the tax revenue can be shared or even remitted completely if the income is subject to tax elsewhere. In the case of portfolio investment, the tax is refunded if the income is reported to tax authorities in the investor's home country. In the case of direct investment, the tax base can be shared with the countries in which production takes place. Because neither provision would depend on the level of the other taxes - instead, each would depend only on whether those taxes were applicable in principle - this method preserves the distinction articulated here between harmful and acceptable tax competition.

I. A Uniform Withholding Tax on Portfolio Investment. - As noted above, the OECD Report does not address the issue of taxation of portfolio investment. Although the EU package contains a draft Directive on this topic, it applies only to payments made within the EU to individual EU residents. Moreover, even this draft may fail in the face of opposition from Luxembourg and the United Kingdom, which fear that their lucrative Eurobond markets might flee to Zurich or New York if the Directive were adopted. ${ }^{452}$

This situation does, however, present a golden opportunity. As Part II recounts, the problem of nontaxation of cross-border interest flows stems largely from the unilateral enactment of the portfolio interest exemption by the United States in 1984 . That enactment was driven by the need to finance a growing budget deficit and by the fear that any tax withheld on portfolio interest flows from the United States would simply be shifted forward to the U.S. borrowers, including the U.S. Treasury.

Whatever merit these contentions had in 1984 , they have none now. ${ }^{453}$ The United States is enjoying a budgetary surplus, and because it is perceived as a safe haven in financially troubled times, its borrowers are unlikely to bear the cost of any withholding tax on interest. Thus, the United States could probably repeal the portfolio interest exemption immediately without suffering adverse consequences. Further work in this area by economists is clearly desirable.

Even if the repeal of the portfolio interest exemption on a unilateral basis were to lead to adverse consequences for the United States, the

\footnotetext{
452 See EU Savings Tax Gains Strength Before ECOFIN Meeting, I999 WORLDWIDE TAX DAILY 195-5, available in WL 1999 WTD $195-5$.

453 See supra pp. 1580-81.
} 
prospective OECD report and the EU position render multilateral action much more likely. As observed in Part II, the nontaxation of cross-border interest flows is an assurance game: each player (the EU, the United States, and Japan) refrains from taxing for fear of driving investment to the others, even though they would all benefit from imposing the tax. Nevertheless, such assurance games can be resolved if parties can credibly signal to each other their willingness to cooperate. ${ }^{454}$

The EU draft Directive represents just such a signal. The EU is telling the United States that it is willing to go forward with taxing cross-border interest flows, and even Luxembourg and the United Kingdom are indicating willingness to cooperate if the United States and Japan agree to follow the EU's lead. Thus, if in the context of the OECD Report on taxation of interest the United States and Japan were to commit themselves to taxing cross-border interest flows, the assurance game could be resolved and a new, stable equilibrium of taxing, rather than forgoing taxation, be established. 455

The prospects for agreement in this area are particularly good because only a limited number of players need be involved. The world's savings may be parked in traditional tax havens, but the tax havens' cooperation is not needed. To earn decent returns without incurring excessive risk, investors must use the markets in the EU, the United States, Japan, and Switzerland. Thus, if the OECD member countries could agree to the principles adopted by the EU in its draft Directive, they could effectively tax cross-border portfolio interest flows.

This Article therefore proposes that the OECD implement, on a coordinated basis, the principles contained in the EU draft Directive on taxation of savings. However, although in the EU context exchange of information plays a large role in ensuring taxation because there are few traditional tax havens there, in a global context withholding taxes must be the primary means of enforcement. As noted above, traditional tax havens with strong bank secrecy laws render it very difficult to exchange information effectively among OECD member countries.

\footnotetext{
454 See Mancur Olson, The logic of Collective action: Public Goods and the THEORY OF GROUPS 45 (I965) ("W]hether a group will have the capacity to act, without coercion or outside inducements, in its group interest ... depends on whether the individual actions of any one or more members in a group are noticeable to any other individuals in the group.").

455 The United States's role in this regard would be more that of a follower than that of a leader. It is unfortunate that in enacting the portfolio interest exemption the United States abandoned the role of a positive leader in international tax affairs that it had played by being the first to adopt the foreign tax credit and CFC rules. Nevertheless, even if it were to follow Europe, the United States would occupy a decisive place in breaking the current impasse. Japan is likely to cooperate because it also suffers from the current regime (the portfolio interest exemption was enacted to attract Japanese investors who wish to avoid tax in Japan) and has led the OECD effort to limit harmful tax competition.
} 
If the investment is made through a tax-haven intermediary, exchange of information is likely to be useless because tax authorities will not know the identity of the funds' owner.

Therefore, instead of the "co-existence" model of the EU, the OECD should adopt a uniform withholding tax on cross-border interest flows, which should also be extended to royalties and other deductible payments on portfolio investments. ${ }^{456}$ To approximate the tax rate that would be levied if the payments were taxed on a residence basis, the uniform withholding tax rate should be at least $40 \%$. However, unlike the withholding taxes that were imposed before the current race to the bottom began in 1984 , the uniform withholding tax should be completely refundable. To obtain the refund, as suggested by the EU draft Directive, a beneficial owner need only show the tax authorities in the host countries a certificate attesting that the interest payment was reported to the tax authorities in the home country. No actual proof that tax was paid on the interest income is required; from efficiency, equity, and revenue perspectives, the country of residence needs only the opportunity to tax foreign investment income just as it taxes domestic. ${ }^{457}$ Thus, in accordance with the distinction drawn in section III.E, even if the home country imposes a low generally applicable tax rate on its residents (or even a zero tax rate, as long as it applies to all bona fide residents), the resident could obtain a refund by reporting the income to the tax authorities in his home country. ${ }^{458}$

Neither the proposed withholding tax nor the refund mechanism would require a tax treaty. Nevertheless, countries could reduce or eliminate the withholding tax in the treaty context when payments are made to bona fide residents of the treaty partner. In those cases, the exchange of information among treaty countries should suffice to ensure residence-based taxation. Because most OECD members already have tax treaties with most other members, the proposed uniform withholding tax would generally apply only to payments made to nonOECD member countries, including traditional tax havens.

\footnotetext{
456 Extending the tax to nondeductible payments, such as dividends, may also be advisable, but this step is less crucial. See Avi-Yonah \& Swartz, supra note 16 , at $25 \mathrm{r}$.

457 Developing countries might obtain a direct transfer of the funds from the OECD member country, which they would then credit against domestic tax liability. The OECD member would retain a small percentage of the tax as a fee for its collection assistance. For a precedent for this type of procedure, see Interim Agreement on the West Bank and the Gaza Strip, Sept. 28, 1995, Isr.-Palestine Liberation Org., ann. V, app. I, 36 I.L.M. 55 I, 640, which establishes a system under which Israel collects taxes from Palestinians working within its borders and remits $75 \%$ of the revenue to the Palestinian National Authority.

458 This tax would apply to individuals, and residence would thus be a meaningful concept. If an individual chose to live in a Caribbean tax haven, he could, under the proposal, avoid tax on his foreign source investment income. Presumably, living in a tax haven would entail giving up certain public services in exchange for lower taxes.
} 
Were OECD members to enact such a uniform withholding tax, it would go a very long way toward solving the problem of undertaxation of cross-border portfolio investments by individuals. Such under-taxation is unacceptable from either an efficiency or an equity perspective. Moreover, unlike the under-taxation of direct investment, this type of under-taxation is illegal (which is assessing its magnitude is so difficult). By adopting a uniform withholding tax, the OECD could thus strike a major blow at tax evasion, which is a major problem for most developing countries and some developed countries (including OECD members) as well.

2. Consumption-Based Taxation of Multinationals. - The OECD proposals for taxing multinationals on their income from international operations are adequate in the short run. Eighty-five percent of multinationals' parent corporations now reside in OECD member countries. If adopted by all members, the OECD proposal for an effective CFC regime would therefore solve eighty-five percent of the problem.459 Moreover, the OECD Report answers the common argument made by multinationals against $C F C$ regimes that was examined in section III.A: If all OECD member countries adopt effective CFC regimes, then all multinationals resident in those countries will compete equally ${ }^{460}$

In the longer run, however, multinationals may well establish their parent corporations' residences in non-OECD member countries (or in OECD members that do not subscribe to the Report, like Luxembourg or Switzerland). In that case, the application of CFC regimes is likely to be ineffective. The solution envisaged by the OECD Report is to redefine residence based on the residence of shareholders, but for those multinationals whose shares trade on many exchanges, this proposal is likely to be ineffective or very costly to administer in practice. ${ }^{461}$

Accordingly, this Article proposes instead that the OECD adopt a regime that taxes multinationals as an initial matter in the country

459 Current CFC regimes, however, do not observe the OECD Report's distinction between generally applicable rate reductions and targeted tax havens. See OECD REPORT, supra note 26, at 4 I ("CFC rules may also apply in situations which do not involve harmful tax practices as defined in this Report. It is recognised that countries retain their right to use such rules in such situations.").

460 This response exposes the flaw in current arguments to restrict the scope of Subpart $F$ based on competitiveness, see, e.g., NFTC PROJECT, supra note $33, \mathbb{2} 262$ ("[L]oss in world market-share ... can occur where it is difficult for U.S. multinationals to offset the higher tax burdens imposed by [S] ubpart $\mathrm{F}$ through cost advantages or product differentiation."). Another field of law offers an interesting precedent for this type of situation: U.S. multinationals have argued since 1977 that the Foreign Corrupt Practices Act, I5 U.S.C. $\$ \$ 78 d d-1$ to -3 (I994 \& Supp. IV I998), restricts their ability to compete effectively overseas against foreign multinationals. These complaints have lost their force since the OECD adopted strict anticorruption guidelines in 1996 .

461 See supra p. $1666 \&$ n.45I. 
that consumes the goods or services the multinational provides. ${ }^{462}$ The advantage of choosing that country (the "demand jurisdiction") as the locus of initial taxation is that large consumer markets are unlikely to be tax havens and are likely to want to impose tax on foreign importers as well as on domestic sellers. Consider the popularity of the destination principle for consumption taxes such as the VAT or the United States's retail sales taxes. Such taxes are imposed on a destination basis without the need for a coordinating tax treaty. ${ }^{463}$

The first step toward imposing such a tax would be to modify the permanent establishment threshold embodied in tax treaties and domestic legislation. The current threshold relies on physical presence, but as Part II explains, that concept is obsolete and is likely to lead to under-taxation of multinationals that can sell in a jurisdiction without having a physical presence therein. Thus, as I have proposed elsewhere, a different type of threshold is required, one that will not be linked to physical presence. ${ }^{464}$ Such a threshold could be a de minimis amount of sales into the jurisdiction, as suggested in the state sales tax context by Walter Hellerstein. ${ }^{465}$ For example, the rule for the United States could be that a seller with gross sales of $\$$ I million or less within a given tax jurisdiction (adjusted for inflation) would not be subject to taxation at source. ${ }^{466}$

The determination of what constitutes a sale into a jurisdiction is obviously a key issue in applying the proposed rule. Fundamentally, the inquiry should begin by defining the area in which buyers consume the goods and services. Such a determination is difficult to make without a proxy. A billing address is adequate for most individual customers for two reasons. First, they are unlikely to consume the prod-

462 This proposal is based on a similar one for electronic commerce. See Avi-Yonah, International Taxation of Electronic Commerce, supra note 40, at 548-49. That proposal, however, was not limited to harmful tax competition. The OECD Report does mention as a "topic for further study" the possibility of denying deductions for payments to tax havens, citing a Spanish precedent, but then fails to elaborate. OECD REPORT, supra note 26 , at $59-60$.

463 They are thus operationally independent from the international tax system. $C f$. Charles $\mathrm{E}$. McLure, Jr. \& George R. Zodrow, The Economic Case for Foreign Tax Credits for Cash Flow Taxes, 5I NAT'L TAX J. I, I-22 (I998) (arguing for the inclusion of such taxes in the system by granting a credit for their payment, which the IRS currently does not do). Imposing income taxes pursuant to a destination principle will not violate the WTO rules if the destination country imposes those taxes on domestic producers and rebates them if countries in which production takes place impose a tax. See Victoria P. Summers, The Border Adjustability of Consumption Taxes, Existing and Proposed, I2 TAX NOTES INT'L I 793, I 795 \& n.Io (I996).

464 See Avi-Yonah, International Taxation of Electronic Commerce, supra note 40, at 535-36.

465 See Walter Hellerstein, State Taxation of Electronic Commerce, 52 TAX L. REV. 425, 50I-02 (1997). Aggregation rules would be required to prevent manipulation of the threshold.

466 This Article recommends a gross sales threshold, rather than a net income threshold, because the latter requires information from outside the destination jurisdiction about the taxpayer's income. For the same reason, a threshold based on a percentage of total sales worldwide seems impracticable because such a method requires knowledge available only to the taxpayer. 
uct elsewhere. Second, they have no incentive to provide a false address because they typically do not bear the tax burden. By contrast, these two factors may be absent for business customers, because the billing address may be anywhere (including in a tax haven) and because, in the case of large customers, collusion is a possibility. However, the fact that business customers are physically located in the taxing jurisdiction means that an audit may determine where the business consumed the product. Moreover, purchasing goods or services in a high-tax jurisdiction would maximize the value of the deduction a business customer could take when it determines its own tax liability. This factor would provide a strong incentive for business customers to increase purchases from these jurisdictions.

The proposed withholding tax regime would include the following rules:

(a) A Gross Withholding Tax. - The demand jurisdiction imposes on foreign businesses a gross withholding tax on sales and services at a rate equal to the corporate tax rate in the demand jurisdiction. As explained above, a sale is defined as being into the demand jurisdiction if the goods or services are consumed therein under rules similar to a destination-based VAT. The demand jurisdiction may impose a gross withholding tax by forbidding merchants from selling goods to its residents unless procedures for withholding the tax are in place. 467

(b) Filing. - To obtain a refund or reduction of the gross tax, the taxpayer must file a return showing its deductions and including the cost of the goods sold. Thus, the function of the gross withholding tax is to force the taxpayer to file a return in a jurisdiction where she has no physical presence. 468 It may therefore be advisable to allow a full refund at this point if the total gross sales fall below the expanded threshold. The remaining rules would then apply only if the total gross sales exceeded the threshold. ${ }^{469}$

(c) Third-Party Limitations. - The demand jurisdiction disallows deductions to parties that are located in supply and residence jurisdictions that have tax incentives targeting foreigners, unless those parties file returns in and pay taxes to the demand jurisdiction. This rule preserves the distinction between jurisdictions that engage in harmful tax competition - tax incentives targeting foreigners - and jurisdictions

467 Given that the proposal implicates coordinated OECD action, it will cover most large markets. Thus, countries need not fear that the imposition of their tax regime will drive sellers away from their markets.

468 This requirement for withholding gross income is similar to the rule for U.S. real estate transactions. See I.R.C. \& 1445 (1994).

469 Although a threshold will enable some income to escape taxation, it is necessary to shield small businesses and to prevent situations in which the cost of compliance exceeds the profit that businesses derive from the transaction. For a fuller discussion, see Avi-Yonah, International Taxation of Electronic Commerce, supra note 40 , at 532-45. 
that have low, generally applicable tax rates. ${ }^{470}$ Thus, all income that another supply jurisdiction does not tax under targeted tax incentives becomes taxable by the demand jurisdiction. However, income that is taxed elsewhere at a rate lower than that in the demand jurisdiction thanks to generally applicable tax reductions is not taxed in the demand jurisdiction. ${ }^{471}$

This rule is similar to current rules that reflect the view that a source or residence country should not reduce its tax unless it can be sure that the income is really subject to tax elsewhere. For example, a VAT rule allows deductions for inputs only for purchases from registered VAT payers. ${ }^{472}$ However, the proposed rule is limited to those countries that engage in harmful tax competition and allows for more flexibility than the current rules.

It should be emphasized that under the proposed regime the demand jurisdiction would reach only income that is untaxed in the production jurisdiction because of production tax havens, or income that does not belong to any jurisdiction. ${ }^{473}$ The proposed regime would also allocate to the demand jurisdiction any income that is untaxed in the residence jurisdiction because of incentives targeting foreign corporations. Because the demand jurisdiction is less likely to be a tax haven than is either the residence or production jurisdiction, one should view its taxation regime primarily as a mechanism for the prevention of harmful tax competition.

(d) Refunds. - The demand jurisdiction refunds the difference between the gross tax and the net tax according to the return. The net tax is then credited by the corporation's residence jurisdiction if it imposes a corporate tax. ${ }^{474}$ If the residence jurisdiction has an integrated tax regime, credit for the net tax should exist at the shareholder level.

Although this system appears quite complex, it is fundamentally similar to the rules for a destination-based VAT, except that the tax

\footnotetext{
470 A look-through rule would be needed to prevent sellers from selling into the demand jurisdiction via independent, low-profit distributors who are located in a jurisdiction that does not engage in harmful tax competition. In most cases, however, multinational enterprises prefer to control the distribution of their products, as evidenced by their choice to engage in costly FDI rather than to sell to independent distributors. See id. at 537-39.

471 A rule similar to the anti-subsidies rule of I.R.C. \& goI(i) would prevent countries from engaging in harmful tax competition through targeted subsidies rather than tax reductions. Such a rule would treat a targeted subsidy as equivalent to a targeted tax break.

472 A VAT rule also reflects some aspects of the current international tax regime, such as the denial of tax sparing credits, the anti-treaty-shopping rule, and most recently, the hybrid entity rules. See I.R.C. \& 894(c) (Supp. III I997).

473 In the case of related parties, transfer pricing principles that are based on a profit split should apply and only the residual profit should be allocated to the demand jurisdiction. See Avi-Yonah, International Taxation of Electronic Commerce, supra note 40, at 545-50.

474 Resident taxpayers should not receive credit for taxes that the denial of deductions imposes on the unaffiliated.
} 
base is net income and not consumption. ${ }^{475}$ These destination-based VAT rules seem to operate quite well (with a few notorious exceptions, such as banks) and do not seem to require an elaborate tax treaty network to allocate the tax base among countries. Similarly, the proposed rules can be adopted by the OECD demand jurisdictions acting in concert, but may even be adopted by a majority if some members dissent. Moreover, the information that the demand jurisdiction requires to implement the rules relates to other countries' tax systems, which it can readily discern, rather than to the specific tax characteristics of the individual taxpayer, which are harder to ascertain. ${ }^{476}$

The OECD can adopt this proposal as a way to limit harmful tax competition in situations in which rules based on corporate residence or CFC regimes do not work. The key to this proposal, just as to the withholding tax proposal, is that the tax base is shared with those countries that do not engage in harmful tax competition. However, the tax base shifts from production tax havens and headquarters tax havens toward the demand jurisdiction by applying the rules that disallow deductions to parties who use such havens.

Given this shift in the tax base, the proposal may seem regressive, especially considering that production tax havens tend to be developing countries. By contrast, demand jurisdictions tend to be the richest countries in the world, for the richer a country is, the higher its demand for goods and services. However, assuming that the analysis in Part IV is correct and that developing countries engage in tax competition mostly out of fear of losing investments to other developing countries, the likely effect of the proposal would be to stop this race to the bottom. Nonetheless, developing countries could benefit by imposing their taxes on multinationals that produce within their borders without fearing that other countries could undercut them by offering production tax havens. Generally applicable tax reductions would be available as a policy tool, but for the reasons stated above, they are unlikely to be a major determinant in attracting investments. ${ }^{477}$ Thus, the result of the proposed OECD actions could benefit, rather than harm, developing countries that could use the extra revenues, as discussed in Part IV. Countries would attract investments based on their comparative advantages in non-tax areas and on their generally applicable tax rates, not because of harmful tax competition.

\footnotetext{
475 See, e.g., Value Added Tax: A Model Statute and Commentary, I989 A.B.A. SEC. TAX'N 6566.

476 Many countries have CFC regimes that hinge on whether the other country imposes a sufficient tax rate. For example, Australia takes even sub-country tax variations into consideration. See AULT, supra note 346 , at 387 . In all cases, the burden of proof will be on the taxpayer to show that she is subject to tax.

477 Profits are likely to be lower if overall public services are lower, See supra p. I627.
} 


\section{CONCLUSION}

The preceding analysis can be summarized as follows: Tax competition has resulted in a significant potential for evasion and avoidance of taxation on the income from cross-border portfolio and direct investments, which may lead to significant tax base erosion and revenue losses (Part II). Although avoidance interferes with global efficiency and equity, any actions to restrict tax competition must also weigh the need to allow democracies to determine the size of their governments (Part III). Moreover, unrestrained tax competition threatens the socialinsurance safety net in developed countries at a time when such countries are facing a severe fiscal crisis. Likewise, unrestrained tax competition is generally not in the best interest of developing countries. In balancing the competing revenue needs of developed and developing countries, inter-nation equity indicates that tax structures should prefer the latter over the former (Part IV).

Part $\mathrm{V}$ then argues that the design of the EU and OECD efforts to restrict tax competition reveals that the OECD, whose members are currently both the destination of most portfolio investment and the largest markets, is better positioned to implement changes. Thus, the OECD can effectively implement solutions that depend on withholding taxes that the source country levies for portfolio investment and that the demand jurisdiction levies for direct investment. The purpose of the proposed withholding taxes is to enable residence jurisdictions to levy tax on portfolio investment and source jurisdictions to levy tax on direct investment, without the limitations that unrestricted tax competition imposes. The outcomes in both cases are favorable to developing countries in terms of inter-nation equity.

The purpose of this Article is to show that as a result of globalization and tax competition, countries that act unilaterally or by bilateral tax treaties can no longer set tax rules. In a world in which capital can move freely across national borders and MNEs are free to choose from among many investment locations, the ability of any one country (or any two countries in cooperation) to tax (or otherwise regulate) such capital is severely limited. Other countries will undercut any such unilateral attempt. Thus, for the sake of preserving national competitiveness, most countries will make no attempt to restrain the mobility of international capital. A multilateral solution (such as the OECD-based proposal Part V offers) is therefore essential if the fundamental goals of taxation are to be preserved. Only organizations with an equally global reach can regulate or tax private market activities.

This Article delineates some of the ways in which global governance can develop in the area of capital income taxation. Attaining this goal will be difficult, given the expected resistance both of private actors, who are eager to preserve their freedom from taxation, and of 
governments, which are concerned about preserving their sovereign authority to set their own tax rules. Nevertheless, international governance is not impossible. Because preserving the ability of nations to tax income from capital is essential to the achievement of several fundamental goals, such as the development and preservation of an adequate social safety net, it must be attempted. 